Review

\title{
Amide Bond Activation of Biological Molecules
}

\author{
Sriram Mahesh, Kuei-Chien Tang and Monika Raj * \\ Department of Chemistry and Biochemistry, Auburn University, Auburn, AL 36849, USA; \\ mzs0154@auburn.edu (S.M.); kzt0026@tigermail.auburn.edu (K.-C.T.) \\ * Correspondence: mzr0068@auburn.edu; Tel.: +1-334-844-6986 \\ Academic Editor: Michal Szostak \\ Received: 7 September 2018; Accepted: 9 October 2018; Published: 12 October 2018
}

\begin{abstract}
Amide bonds are the most prevalent structures found in organic molecules and various biomolecules such as peptides, proteins, DNA, and RNA. The unique feature of amide bonds is their ability to form resonating structures, thus, they are highly stable and adopt particular three-dimensional structures, which, in turn, are responsible for their functions. The main focus of this review article is to report the methodologies for the activation of the unactivated amide bonds present in biomolecules, which includes the enzymatic approach, metal complexes, and non-metal based methods. This article also discusses some of the applications of amide bond activation approaches in the sequencing of proteins and the synthesis of peptide acids, esters, amides, and thioesters.
\end{abstract}

Keywords: peptide bond cleavage; amide bond resonance; twisted amides; enzymes; metal complexes; catalysts

\section{Introduction}

The amide bond is one of the most abundant chemical bonds and widely exists in many organic molecules and biomolecules [1-6]. Nature has used amide bonds to make these important biomolecules because of the high stability of amide bonds towards various reaction conditions (acidic and basic conditions), high temperature, and the presence of other chemicals [7]. The high stability of amide bonds is attributed to its tendency to form a resonating structure, which provides a double bond character to the amide CO-N bond (Figure 1) [8-10]. The resonance of these amide bonds forms a planar structure and hinders the free rotation around the CO-N bond, thus, it is responsible for 3D structures adopted by proteins and other biomolecules. These 3D structures of biomolecules are responsible for various important biological functions.

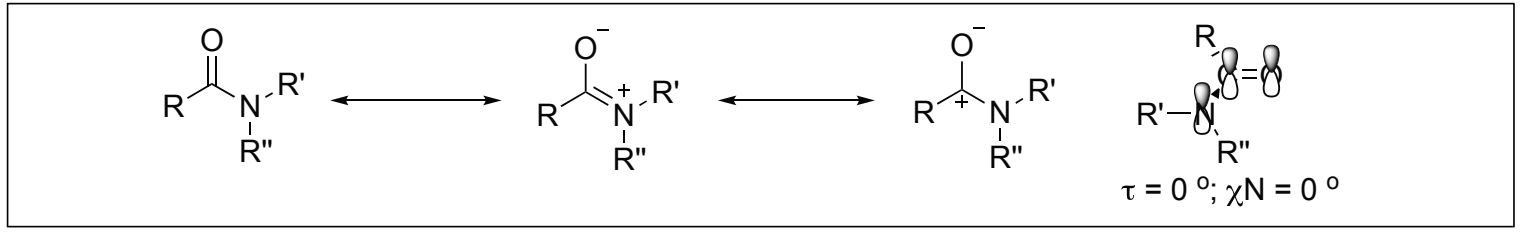

Figure 1. Classical amide bond resonance.

Hansen et al. carried out the rate studies on the hydrolysis of amide bonds at various $\mathrm{pH}$ conditions [11]. The study concluded that at $\mathrm{pH} \mathrm{7,} \mathrm{the} \mathrm{rate} \mathrm{of} \mathrm{hydrolysis} \mathrm{is} \mathrm{due} \mathrm{to} \mathrm{the} \mathrm{direct} \mathrm{attack}$ of water on peptide and measured as $\mathrm{kH}_{2} \mathrm{O}$. The rate constant showed that the half-life of the amide bonds is 267 years, similar to the value determined by Radzicka and Wolfenden [12]. This study also showed that the rates of acid $\left(\mathrm{kH}_{3} \mathrm{O}^{+}\right)$and base hydrolysis $\left(\mathrm{kOH}^{-}\right)$are identical, therefore, the rate of the hydrolysis of the peptide bond is dominated by $\mathrm{kH}_{2} \mathrm{O}$ throughout the $\mathrm{pH}$ range from $\mathrm{pH}$ 5-9. 
Recently, various methods have been reported in the literature to activate the amide bonds towards a variety of nucleophiles or electrophiles for the synthesis of other organic compounds. This includes the use of enzymes, metal complexes, and non-metal based methods [13-15]. One widely reported approach for the activation of amide bonds involves the distortion of amide bonds, thus, the amide bond is no longer able to form a resonating structure, loses its double bond character, and becomes more susceptible to nucleophilic or electrophilic attack. A higher distortion of the amide bond from the planar structure makes it more reactive, as evidenced by various twisted amide bonds present in cyclic nonplanar bridged lactams, as demonstrated by Stoltz [16,17], Kirby [18-20], and others [21-23] (Figure 2). One of the special cases to achieve maximum rotational inversion of the amide bond so that it remains in the twisted conformation is the use of $N$-acyl-glutarimides [24-29] and $N, N$-substituted amide bonds [30,31] (Figure 2). It is this strong distortion of amide bonds that provides amide bonds with a high reactivity toward a variety of nucleophiles and electrophiles.

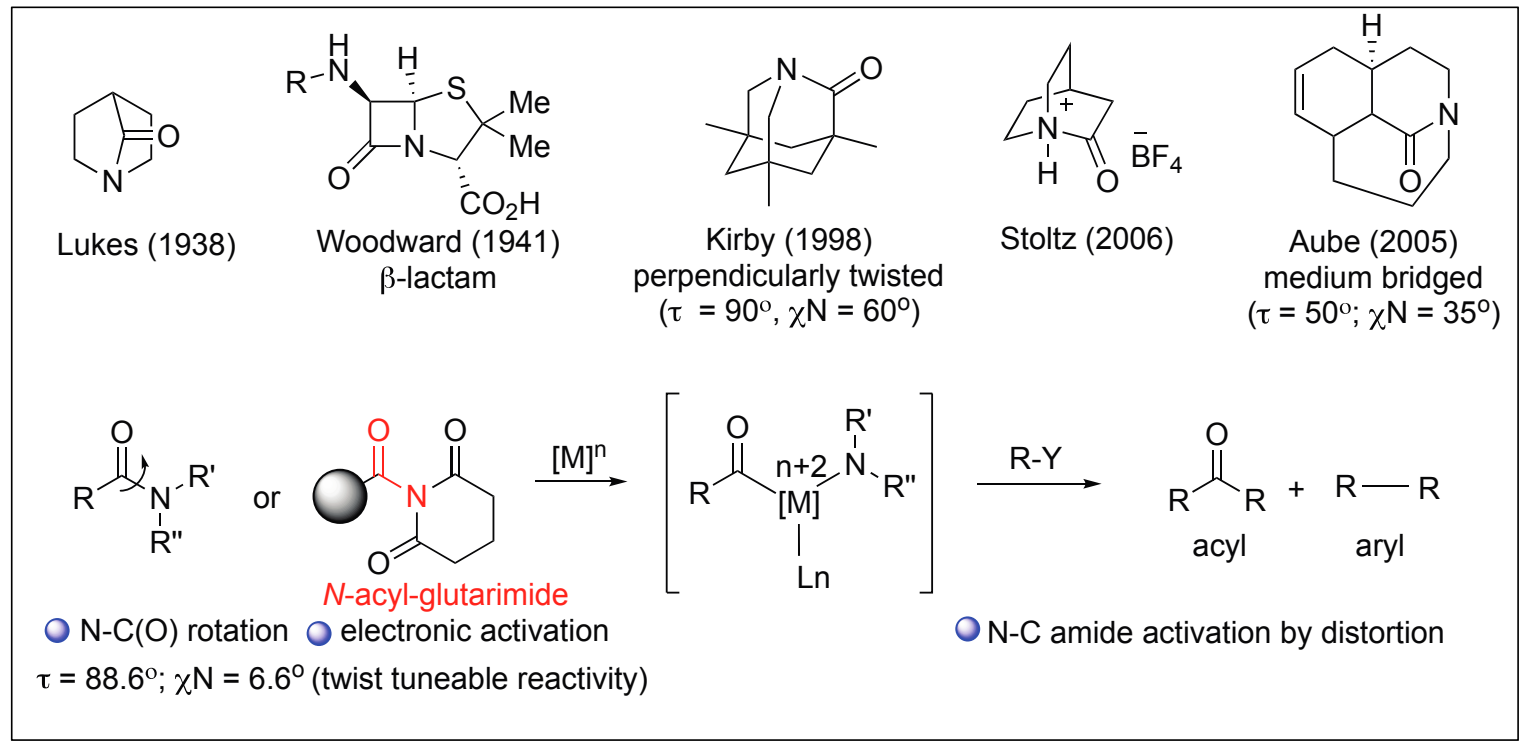

Figure 2. Twisted amides for activation of amide bonds.

There are already some excellent review articles in the literature covering the reactivity of twisted/activated amide bonds for the synthesis of the variety of different organic molecules such as ketones, esters, acids, and alcohols, by cross-coupling reactions [24-31]. The main focus of this review is to summarize the methods for the activation of less reactive amide bonds present in biomolecules such as peptides, proteins, glycopeptides, nucleotides in DNA and RNA and various other peptide bioconjugates, toward attack by various nucleophiles. This task was accomplished by various methods such as by using biological molecules, metal complexes, and non-metal based methods and is discussed below.

\section{Biomolecules for the Activation of Amide Bonds-The Enzyme-Directed Hydrolysis of Amides}

We have summarized different kinds of enzymes, their mechanisms of hydrolysis of unactivated peptide bonds, and the point of cleavages in Table 1. 
Table 1. Enzymatic directed hydrolysis of peptide bonds.

\begin{tabular}{ccccc}
\hline Entry & Enzyme & Method of Hydrolysis & Point of Cleavage & Ref. \\
\hline 1 & $\begin{array}{c}\text { Serine and } \\
\text { Cysteine Proteases }\end{array}$ & $\begin{array}{c}\text { Oxyanion binding hole with } \\
\text { catalytic triad }\end{array}$ & [32-37] \\
\hline 2 & Metallo-endopeptidase & $\begin{array}{c}\text { Thermolysine with } \mathrm{Zn}^{2+} \text { binds to } \\
\text { His 142, His 146, Glu 166 }\end{array}$ & $\begin{array}{c}\text { Internal peptide bonds on the } \\
\text { N-terminal side of large } \\
\text { hydrophobic amino acids }\end{array}$ & {$[38-51]$} \\
\hline 3 & Metalloexopeptidase & $\begin{array}{c}\text { Carboxypeptidase A with Zn }{ }^{2+} \\
\text { through Lewis acid activation }\end{array}$ & $\begin{array}{c}\text { C-terminus comprising large } \\
\text { hydrophobic amino acids }\end{array}$ & {$[52-54]$} \\
\hline 4 & O-GlcNAc transferase & $\begin{array}{c}\text { Glycosylation followed by enzyme } \\
\text { catalyzed pyroglutamate formation }\end{array}$ & N-terminal glutamic acid & {$[55,56]$} \\
\hline 5 & Nicotinamidase & $\begin{array}{c}\text { Enzyme Chelation to Zn }{ }^{2+} \text { and } \\
\text { catalytic triad }\end{array}$ & Nicotinamide & {$[57-60]$} \\
\hline 7 & Flavoenzyme & $\begin{array}{c}\text { Flavin hydroperoxide intiated } \\
\text { oxidative mechanism }\end{array}$ & $\begin{array}{c}\text { Unactivated amide bond } \\
\text { in uracil }\end{array}$ & {$[61-63]$} \\
\hline 8 & Antibody Fab-BL 125 & $\begin{array}{c}\text { Catalyzes unactivated primary } \\
\text { amide bond hydrolysis }\end{array}$ & $\begin{array}{c}\text { Primary amide bond of L-isomer } \\
\text { of peptides }\end{array}$ & {$[64,65]$} \\
\hline
\end{tabular}

\subsection{Serine Proteases}

Amide bonds are widely present in proteins due to their high stability and the tendency of amide bonds to exist in resonating structures, which is one of the key factors responsible for secondary structures adopted by proteins and their biological activities. Nature has developed some methods for the cleavage of highly stable amide bonds to control their functions. One such approach is the use of enzymes (serine proteases), which have active sites, and binding pockets for binding to particular amino acids followed by the activation of amide bonds for hydrolysis. These enzymes exist in various families such as trypsin, chymotrypsin, elastase, subtilisin, etc., but have a similar catalytic site containing oxyanion binding hole with Ser, His and Asp triad [32,33]. Some of the proteases have catalytic dyads with two amino acids at the active site, however, triads are the most common.

All these enzymes based on the binding pocket prefer to bind to particular amino acids but the mechanism by which they hydrolyze the amide bond is similar. During the catalysis, these enzymes form an oxyanion hole made up of three amino acids-His, Asp, and Ser-which work in a synergistic manner to break the amide bond (Figure 3). First, the side chain of Asp makes a hydrogen bond with histidine, thus making it more nucleophilic. Second, histidine forms a strong H-bond with the hydroxyl group of serine and abstracts the proton from the hydroxyl group $(\mathrm{OH})$ of serine which in turn attacks amide bond to form a tetrahedral transition state (TS). This TS eventually collapses resulting in the hydrolysis of the amide bond by acid-base catalysis. Wells et al. demonstrated the importance of these residues at the active site by mutating it to alanine [32,33]. They showed that any mutation in the catalytic triad greatly reduces the turnover number which is a consequence of the changes in the enzyme mechanism. Residues in the catalytic triad function in a strongly synergistic manner and contribute a factor of $2 \times 10^{6}$ to the rate enhancement. The study concluded that enzymes increase the rate of amide bond hydrolysis at by least $10^{9}$ to $10^{10}$ times that of the non-enzymatic hydrolysis of amide bonds. 


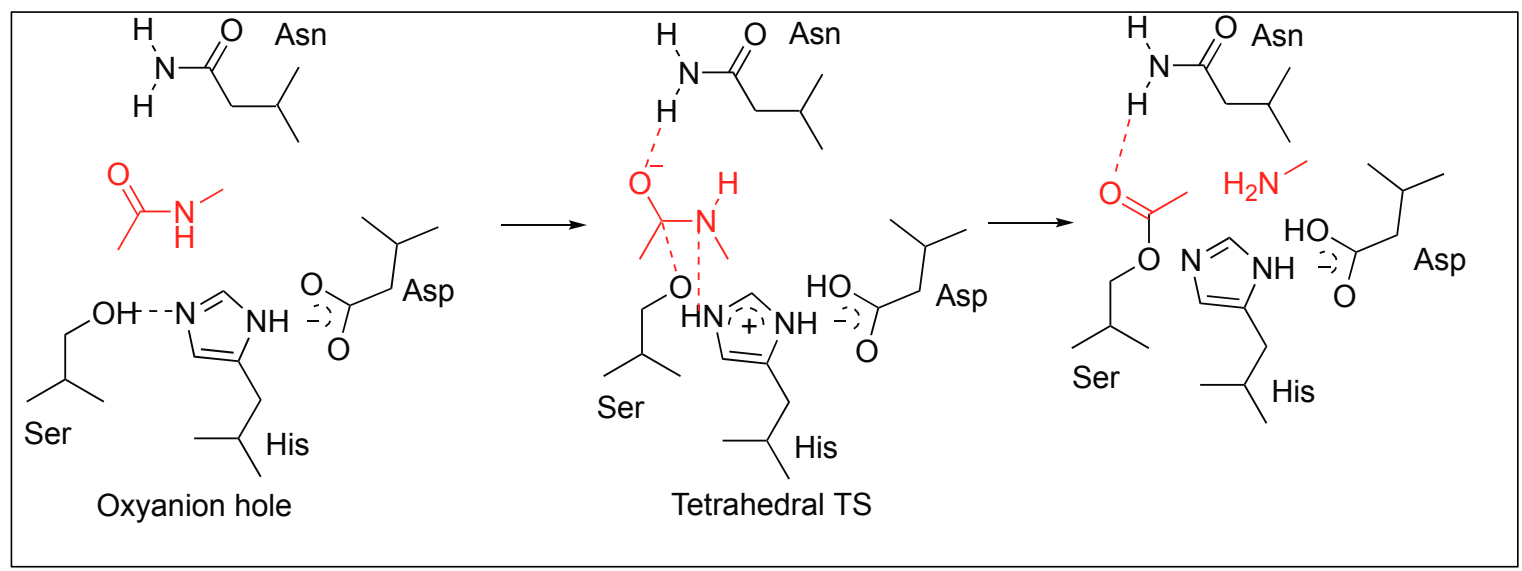

Figure 3. General pathway of serine proteases directed amide bond hydrolysis.

\subsection{Cysteine Proteases}

Cysteine proteases (CPs) hydrolyze the peptide bonds with maximum efficiency at $\mathrm{pH} 4-6.5$ [14]. The thiol group of cysteine protease is susceptible to oxidation so the environment of the enzyme is reducing in nature. Till now 21 families of CPs have been discovered [34-37]. CPs form a triad at the active site during the hydrolysis of the peptide bond made up of Cys-His-Asn residues. First, Asn forms the hydrogen bond with His, then His abstracts the proton from Cys to generate a nucleophilic thiolate ion $\left(\mathrm{S}^{-}\right)$similar to enolate ion generated by serine proteases (Figure 3). Next, the thiolate ion $\left(\mathrm{S}^{-}\right)$attacks the carbonyl group of the peptide resulting in the formation of a tetrahedral intermediate TS followed by the hydrolysis of the amide bond [34-37].

\subsection{Metalloproteases}

Metalloproteases are members of a class of proteases that require a metal ion cofactor at the active site for the hydrolysis of peptide bonds [38]. The most common metal ion cofactor present in metalloproteases is the zinc ion $\left(\mathrm{Zn}^{2+}\right)$ [39]. Other transition metals such as $\mathrm{Co}^{2+}$ and $\mathrm{Mn}^{2+}$ are capable of restoring the functions in zinc-metalloproteases where the $\mathrm{Zn}^{2+}$ core has been removed [39]. Metalloproteases are divided into two major families: metalloendopeptidases and metalloexopeptidases. The names of these families are based on the site of the hydrolysis of the peptide bonds $[40,41]$. Metalloendopeptidases cleave the internal amide bonds whereas metalloexopeptidases cleave the amide bonds present at the $\mathrm{C}$ - or $\mathrm{N}$-terminus of peptides.

\subsubsection{Metalloendopeptidase: Thermolysin}

Thermolysin (TLN) catalyzes the cleavage of the internal peptide bond at the amino-side of large hydrophobic amino acids, such as leucine, isoleucine, or phenylalanine. TLN and TLN-like proteins require $\mathrm{Zn}^{2+}$ as a metal ion cofactor for the cleavage of amide bonds [42-47].

TLN-mediated hydrolysis of the peptide bond is a two-step process (Figure 4) [48-51]. The active site of TLN contains three residues-His142, His146, Glu166 - and a water molecule, which are bound to the $\mathrm{Zn}^{2+}$ ion. First, the carbonyl group of the peptide coordinates with $\mathrm{Zn}^{2+}$ and displaces the hydrogen of a water molecule to form an H-bond with Glu143 and the oxygen of the water molecule remains associated to the $\mathrm{Zn}^{2+}$ ion, resulting in the formation of the enzyme-substrate complex (ES). Second, the oxygen of the water attached to $\mathrm{Zn}^{2+}$ attacks the carbonyl carbon of the peptide, resulting in the formation of transition state 1 (TS1). TS1 is stabilized by the formation of the H-bond with Asp226 and His231 at the carbonyl oxygen of the peptide followed by the formation of intermediate gem-diolate (INT) by the breakage of hydroxyl OH bond of water. The amide of the peptide forms a hydrogen bond with the $\mathrm{H}$ of $\mathrm{H}_{2} \mathrm{O}$. Third, the carbonyl bond rearrangement in TS2 leads to the breakage of the amide bond $(\mathrm{CONH})$ of the peptide and releases the $\mathrm{N}$-terminal peptide. The rate-determining 
studies showed that the collapse of a zwitterionic tetrahedral intermediate (INT) is a rate-limiting step (Figure 4).

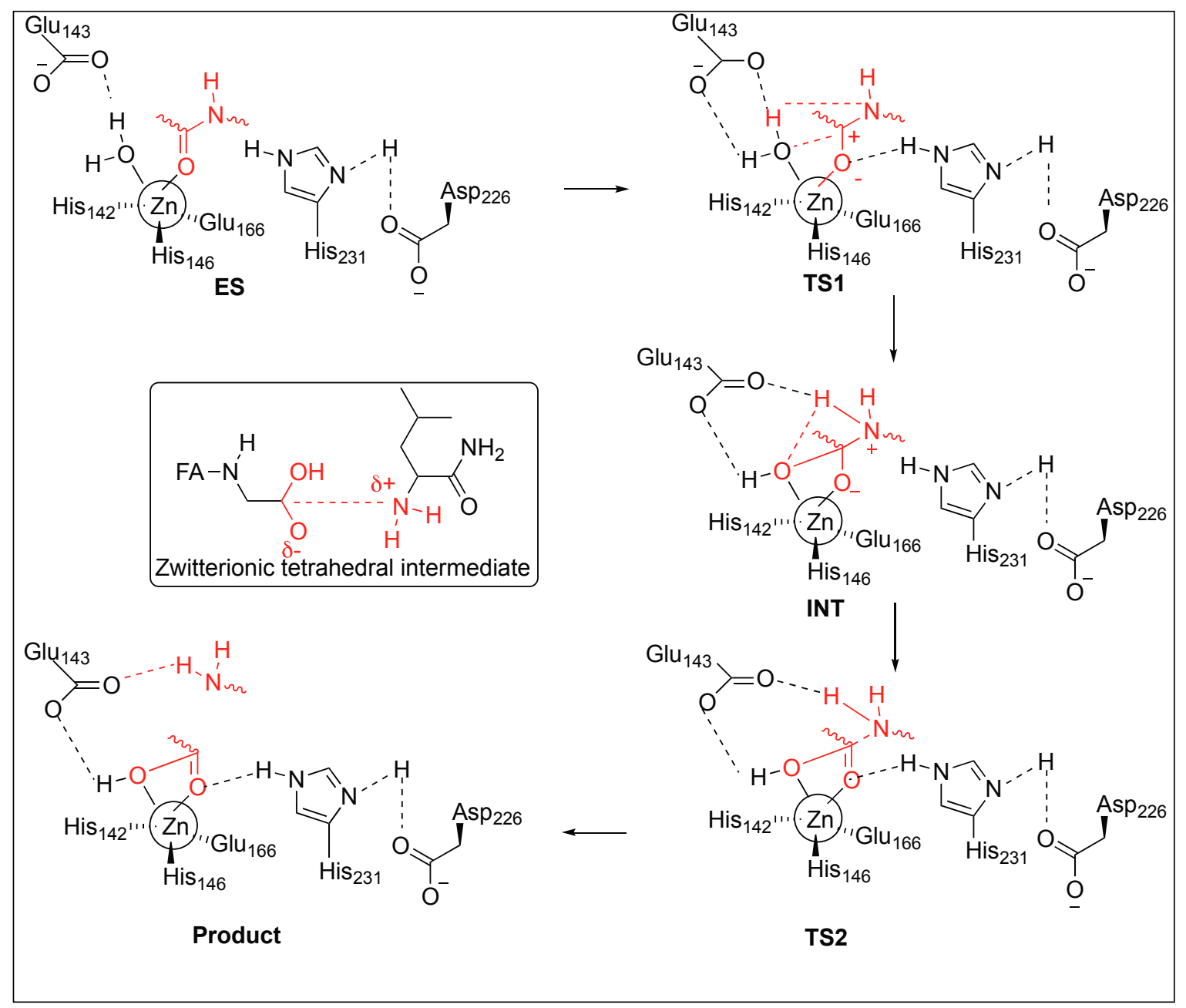

Figure 4. Thermolysin Mechanistic pathway.

\subsubsection{Metalloexopeptidase: Carboxypeptidase A}

Carboxypeptidase A (CPA) is a $35 \mathrm{kDa}$ metalloenzyme and contains a $\mathrm{Zn}^{2+}$ ion cofactor in its active site [52-54]. CPA is an exopeptidase, which catalyzes the hydrolysis of amide bonds present at the C-terminus comprising large hydrophobic side chains. Two different mechanisms have been proposed for the cleavage by these metalloproteases (Figure 5) which showed the importance of Lewis acid catalysis for the activation of amide bonds [53,54]. One involves the Lewis-acid activation of the carbonyl group of the amide bond by $\mathrm{Zn}^{2+}$, followed by the attack of water (Figure 5). The second involves the Lewis-acid activation of $\mathrm{H}_{2} \mathrm{O}$ by $\mathrm{Zn}^{2+}$ ions followed by the attack of the hydroxide ion of the water on the carbonyl group of the amide bond (Figure 5). 


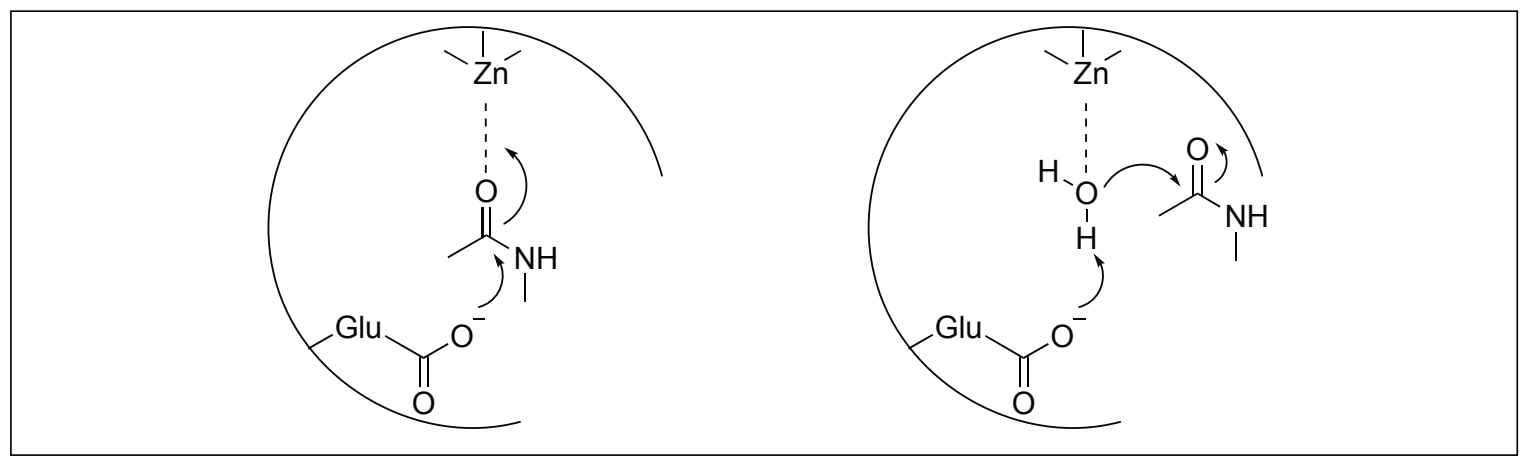

Figure 5. Mechanisms of carboxypeptidase A.

\subsubsection{Glutamate Glycosylation for Amide Bond Cleavage}

Human enzyme O-GlcNAc transferase (OGT) is essential for the cleavage of amide bonds in host cell factor-1 (HCF-1). HCF-1 cleavage takes place at the N-terminal glutamic acid by the glycosylation which is catalyzed by enzyme OGT. Mechanistic studies showed that the glycosylation of the glutamate side chain (intermediate 1, Figure 6) leads to the formation of an enzyme-catalyzed internal pyroglutamate formation (intermediate 2, Figure 6) with the amidic nitrogen of the peptide backbone chain, which then undergoes spontaneous hydrolysis (Figure 6) [55]. Detailed mechanistic studies showed that the rate of conversion of glycopeptide to internal pyroglutamate was an order of magnitude slower than observed in the presence of OGT, thus, it was concluded that both the first and second steps occurred while the peptide is bound to OGT (Figure 6). Hydrolysis likely occurs after dissociation from the enzyme. It has also been reported that glycosylation on Thr next to glutamate also prevents the cleavage at the glutamate (Glu) because of the steric hindrance and thus the enzyme is unable to carry out the glycosylation of glutamate [56].

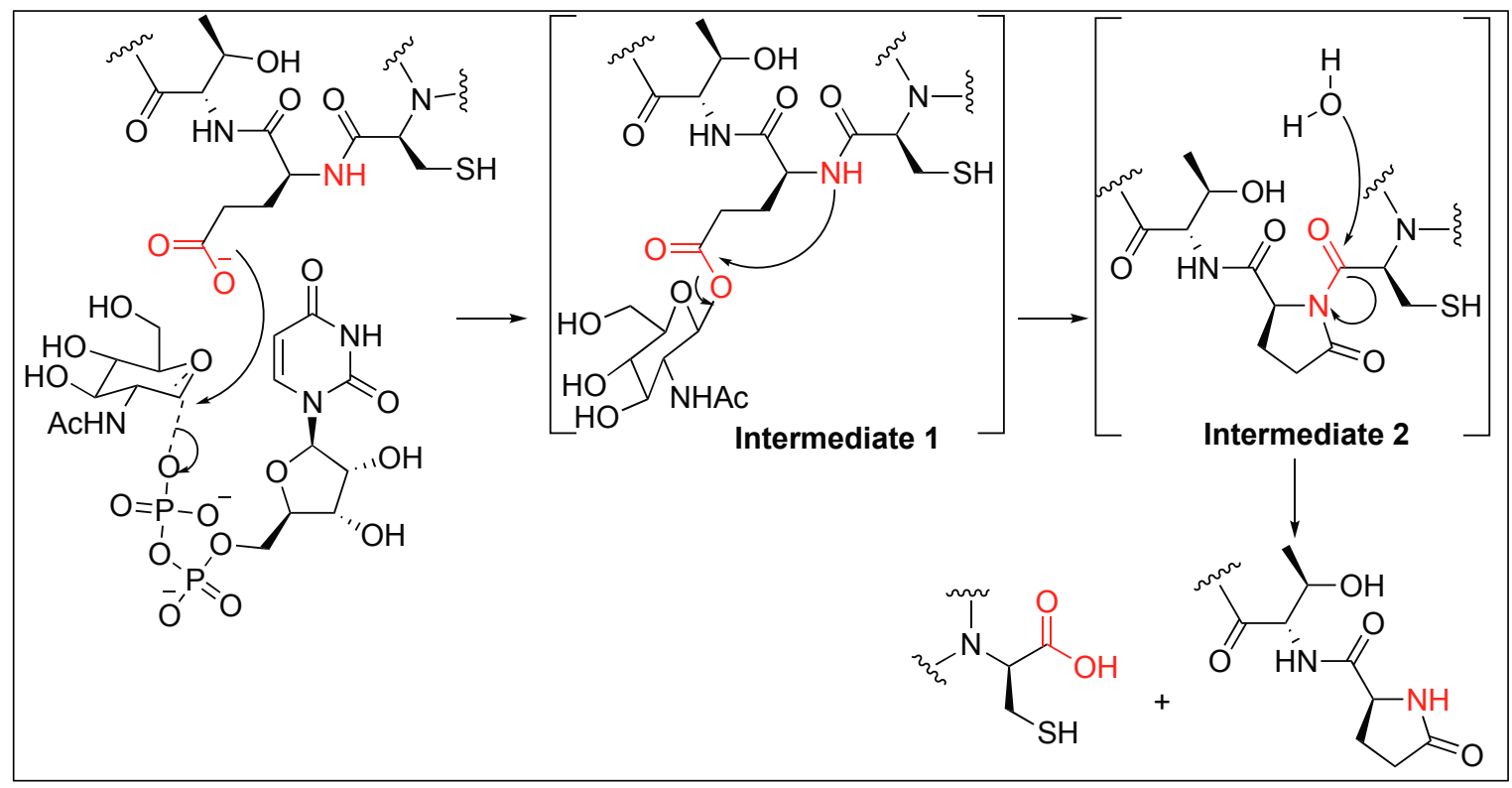

Figure 6. Glycosylation pathway.

\subsubsection{Nicotinamidase (Pnc1) for the Hydrolysis of the Amide Bond of Nicotinamide}

Nicotinamidases catalyze the cleavage of nicotinamide, which is a critically important part of $\mathrm{NAD}^{+}$and NADH, to nicotinic acid and ammonia (Figure 7). A detailed study showed that both the carbonyl oxygen and the ring nitrogen of nicotinamide are critical for binding to the nicotinamidases and reactivity [57-60]. 


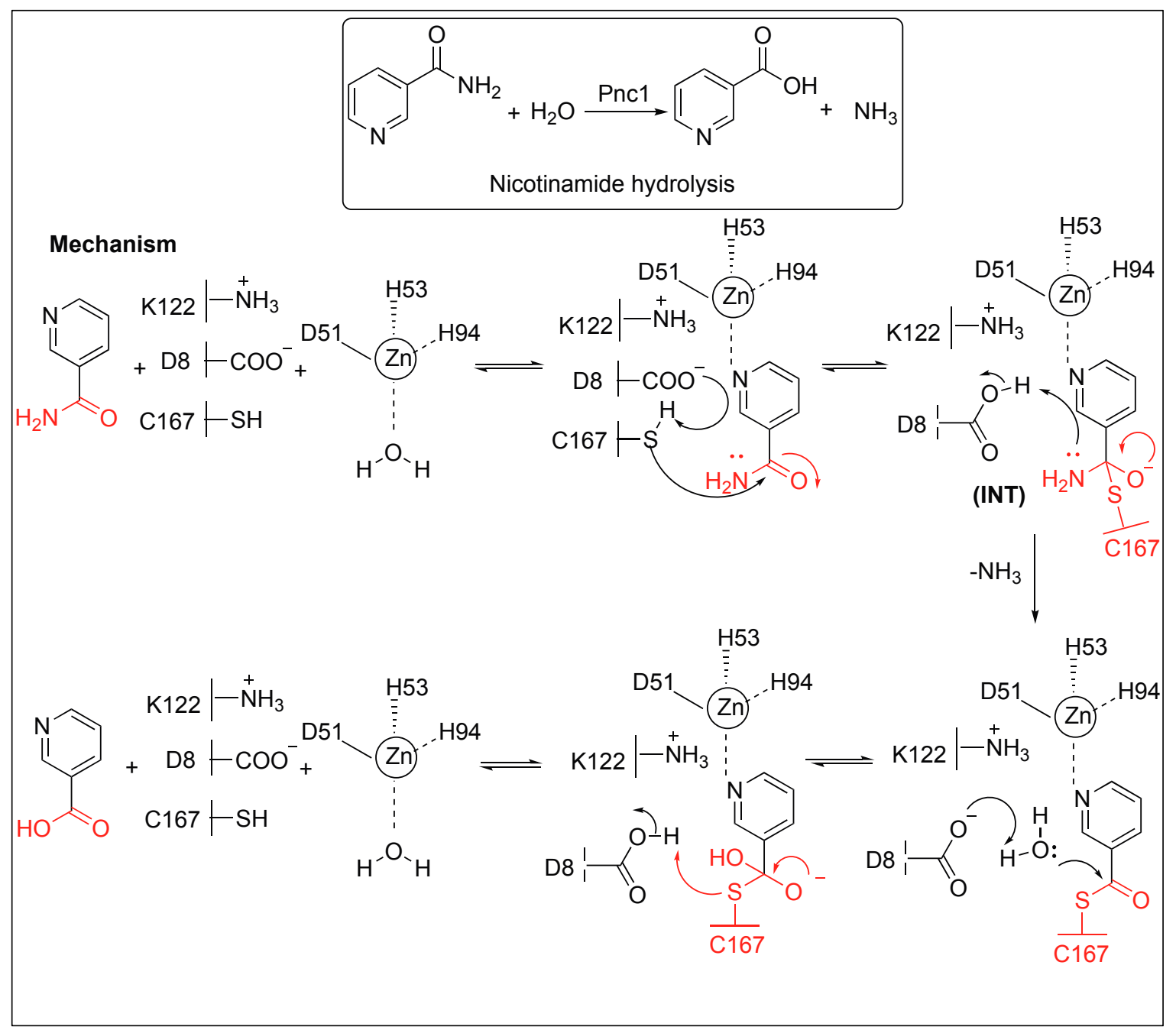

Figure 7. Mechanistic pathway of Pnc1 for hydrolysis of nicotinamide.

Three residues-Asp51, His53, and His94-in nicotinamidase (Pnc1) directly coordinate with $\mathrm{Zn}^{2+}$ at the active site and three other residues act as a catalytic triad (Cys167, Asp8, and Lys122) (Figure 7). In the first step, the substrate binds to the $\mathrm{Zn}^{2+}$ by nitrogen of pyridine ring and displaces the water molecules ligated to the $\mathrm{Zn}^{2+}$. Next, Asp8 removes the proton from Cys167, forming a thiolate, which, in turn, react with the amide carbonyl carbon of nicotinamide, leading to the formation of a tetrahedral intermediate (INT). The tetrahedral intermediate collapsed, resulting in the breakage of the amide bond and release of the ammonia. This is followed by the release of the nicotinic acid from the active site of the enzyme by acid-base catalysis.

\subsubsection{Flavoenzyme-Mediated Hydrolysis of the Amide Bond}

Begley et al. demonstrated the role of flavoenzyme in the cleavage of the unactivated amide bond in uracil, a building block for RNA (Figure 8) [61-63]. The detailed mechanistic analysis showed that the reaction takes place through the oxidative mechanism that is initiated by the addition of a flavin hydroperoxide to the $C^{*}$ carbonyl of uracil, forming a tetrahedral intermediate (INT) (Figure 8). This is followed by the collapsing of the tetrahedral intermediate (INT), leading to the cleavage of an amide bond in uracil. This was the first example where such chemistry was shown by flavin hydroperoxides. 


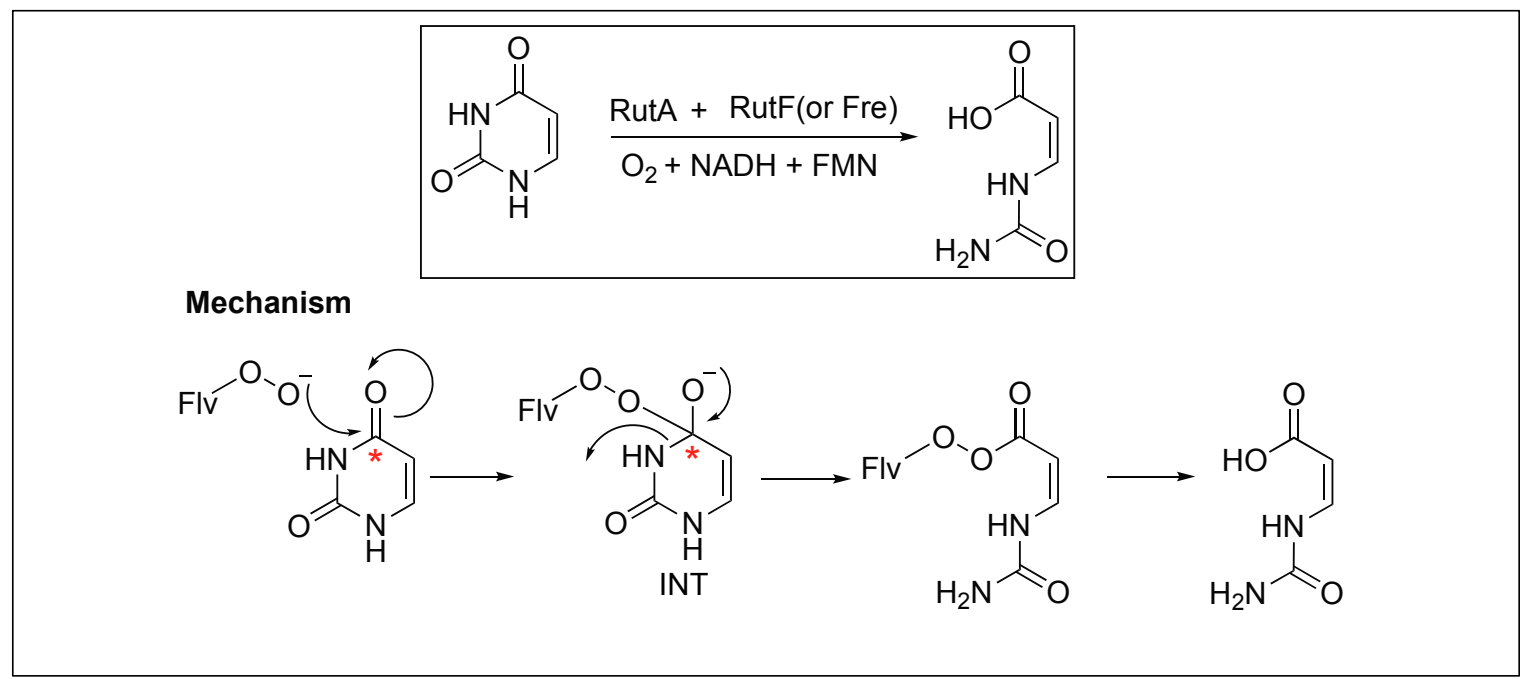

Figure 8. Flavoenzyme-mediated hydrolysis of amide bond.

\subsubsection{Primary Amide Bond Hydrolysis by Antibodies}

The antibody Fab-BL125 catalyzes the hydrolysis of the unactivated primary amide bond of the L-isomer of peptides to generate free peptide acid (Figure 9). The antibody showed high regio- and diastereoselectivity since the D-proline primary amide diastereoisomer did not undergo any hydrolysis. The antibody Fab-BL125 decreases the half-life of the peptide from 17.5 years to only $3.9 \mathrm{~h}$. Such an antibody was obtained by using the $\alpha$-amino boronic acid Hapten by a direct selection strategy from the antibody combinatorial libraries $[64,65]$.

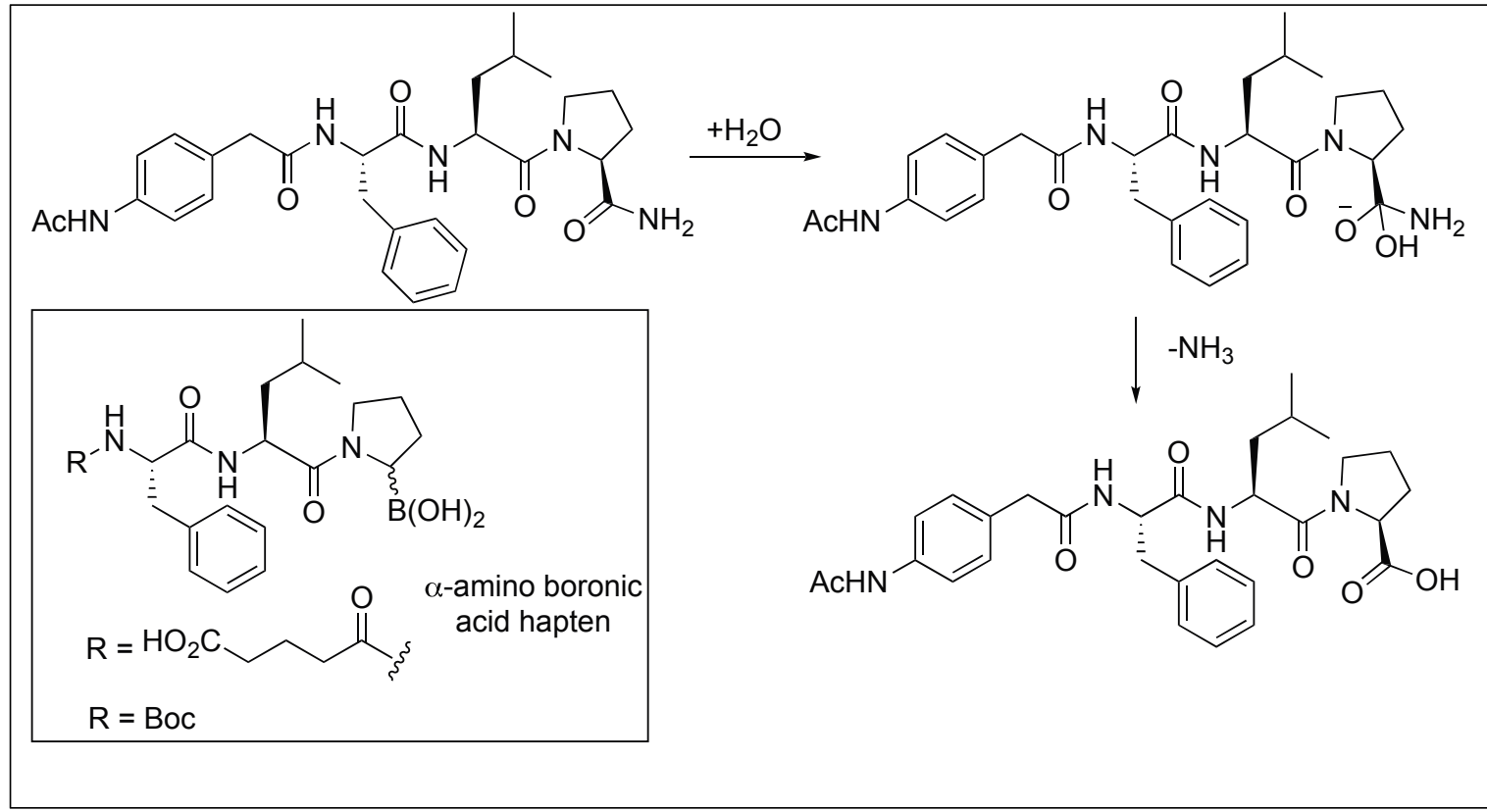

Figure 9. Antibody Fab catalyzed primary amide bond hydrolysis.

\subsubsection{RNA-Assisted Cleavage of Amide Bonds}

A group I RNA obtained by in vitro evolution catalyzes the cleavage of unactivated alkyl amides of DNA analog. This includes substrates with an amide bond that joins either two DNAs, or a DNA with a short peptide. The RNA increases the rate of hydrolysis by more than $10^{3}$ in comparison to the uncatalyzed reaction. The RNA-catalyzed amide bond cleavage was entirely dependent on $\mathrm{Mg}^{2+}$ where $\mathrm{Mg}^{2+}$ acts as a Lewis acid thus activating the carbonyl group of the amide bond for 
the nucleophilic attack by the hydroxy group of RNA (Figure 10). No amide bond cleavage was detected in the presence of other metal ions such as $\mathrm{Zn}^{2+}, \mathrm{Ca}^{2+}$, or $\mathrm{Sr}^{2+}$. A trace amount of amide bond cleavage was observed in the presence of $\mathrm{MnCl}_{2}$ which is in contrast to the RNA and DNA cleavage reactions [66].

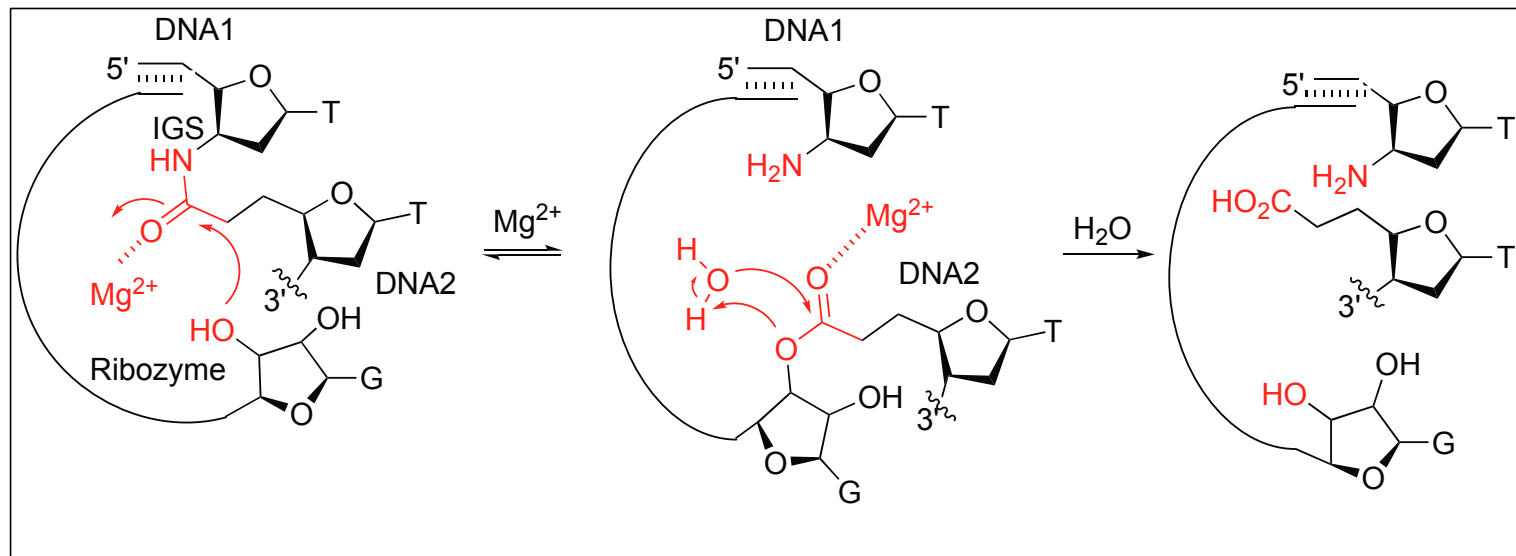

Figure 10. RNA catalyzed amide bond cleavage.

To determine the generality of the amide bond cleavage by RNA, a series of substrates were explored. If a short DNA is attached to a peptide or an amino acid by using an amide bond, the immediate cleavage at the amide bond was observed in the presence of the RNA. The cleavage of the amide bond between the amino acid residues was not observed.

\section{Metal Complexes for the Activation of Amide Bonds}

We have summarized different kinds of metal-based complexes, their mechanisms of hydrolysis of unactivated peptide bonds and point of cleavages in Table 2.

Table 2. Metal catalyzed hydrolysis of peptide bonds.

\begin{tabular}{|c|c|c|c|c|}
\hline Entry & Metal Complex & Method of Hydrolysis & Point of Cleavage & Ref. \\
\hline 1 & Simple metal ions & Lewis acidity of metal ion & C-terminal of peptide & [67-72] \\
\hline 2 & $\begin{array}{c}\text { Zr POMs, } \\
\text { Zr MOF-808 }\end{array}$ & Lewis acidity of metal ion & C-terminal of peptide & [73-82] \\
\hline 3 & $\mathrm{Mo}(\mathrm{VI})$ & $\begin{array}{l}\text { Lewis acidity of metal ion and formation of } \\
\qquad 5 \text { membered ring }\end{array}$ & C-terminal side of Asp & {$[81,82]$} \\
\hline 6 & $\mathrm{Pd}(\mathrm{II}), \mathrm{Pt}(\mathrm{II})$ & $\begin{array}{l}\text { Carboxylic group of amino acid and side chain of } \\
\text { amino acid anchoring metal complex }\end{array}$ & $\begin{array}{l}\text { C-terminal side of Met, His, Cys } \\
\text { and S-MeCys }\end{array}$ & [90-98] \\
\hline 7 & $\operatorname{Pd}(0)$ & Methionine side chain anchoring metal complex & $\begin{array}{l}\text { Second amide bond upstream } \\
\text { from Met }\end{array}$ & [99-102] \\
\hline 10 & $\mathrm{Sc}(\mathrm{III})$ & Lewis acid based N,O acyl rearrangement & N-terminal side of Ser/Thr & [114] \\
\hline
\end{tabular}

Another approach for the cleavage of peptide bonds involves the use of metal complexes. This metal complex has potential applications in the field of chemical biology, biochemistry, and bioengineering. A variety of metal ion complexes has been utilized for testing the reactivity with substrates such as peptides, and proteins [67]. Most of the metal catalyzed reactions reported so far are based on the activation of amide carbonyl or water by the Lewis acid mechanism of the metal 
ion. Another metal ion hydrolysis mechanism involves the formation of a square planar complex of the metal ions $\mathrm{Cu}(\mathrm{II}), \mathrm{Ni}(\mathrm{II})$, or $\mathrm{Pd}(\mathrm{II})$ with the Ser/Thr-His or Ser/Thr-Xaa-His sequence leading to the $\mathrm{N} \rightarrow \mathrm{O}$ rearrangement of the acyl moiety resulting in the cleavage of the peptide bond (Figure 11). In this section, we will provide few examples of both Lewis acid and the $\mathrm{N} \rightarrow \mathrm{O}$ acyl rearrangement for the cleavage of peptide bonds.

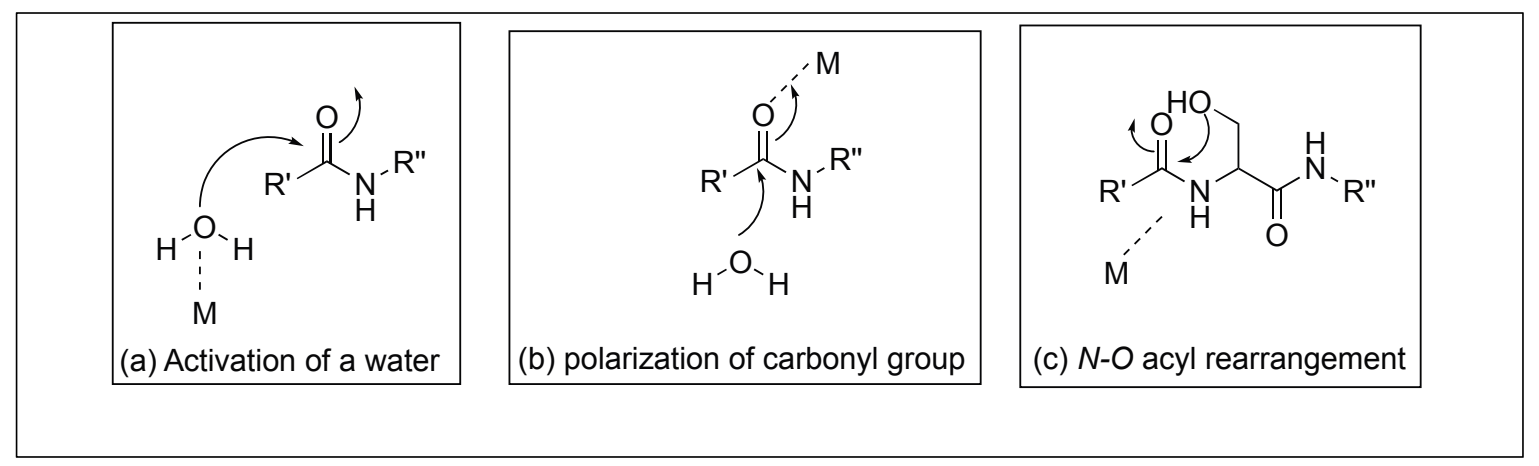

Figure 11. Metal-assisted peptide bond hydrolysis.

\subsection{Lewis Acid Mediated Hydrolysis}

\subsubsection{Simple Metal Ions}

Yashiro et al. reported that the rate of hydrolysis of peptide bonds increases by almost all the metal ions and the highest conversion was observed for $\mathrm{Zn}$ (II) [68-72]. The active intermediate was metal complexes where metal binds to both the carbonyl group and the $\mathrm{N}$-terminal amino group of the peptide bond. Cleavage of the peptide bond in the presence of the metal takes place through the mechanism in Figure 11b.

\subsubsection{Oxo Metal Ions}

Parac-Vogt et al. proved that polyoxometalates oxo-metal compounds such as $\mathrm{MoO}_{2}{ }^{-4}, \mathrm{WO}_{2}{ }^{-4}$, $\mathrm{CrO}_{2}{ }^{-4}$, and $\mathrm{VO}_{2}{ }^{-4}$ cleave the peptide bonds in various dipeptides [73-77]. They have shown that these oxo-metal compounds also hydrolyze the amide bonds in their regular oligomeric forms, polyoxometalates (POMs). A POM is a unit where one or more atoms can be replaced by a metal center leading to the change in the coordination properties of POM. POMs were utilized for the $\mathrm{Zr}(\mathrm{IV})$ - and $\mathrm{Ce}(\mathrm{IV})$-assisted peptide bond hydrolysis because they are homogenous in nature [78,79].

\section{Zirconium Complex Mediated Hydrolysis of Peptide Bonds}

Parac-Vogt et al. reported the hydrolysis of peptide bonds catalyzed by a polyoxometalate complex for the first time. They demonstrated the role of metal-substituted Wells-Dawson type polyoxometalates $\mathrm{K}_{15} \mathrm{H}\left[\mathrm{Zr}\left(\alpha_{2}-\mathrm{P}_{2} \mathrm{~W}_{17} \mathrm{O}_{61}\right)_{2}\right] \cdot 25 \mathrm{H}_{2} \mathrm{O}$ for the hydrolysis of peptide bonds in diglycine, triglycine, tetraglycine, and pentaglycine (GG), yielding glycine as a final product (Figure 12) [80]. A detailed mechanistic investigation by NMR showed that the free amino terminus and both carbonyl functionalities of GG interact with polyoxometalates $\mathrm{K}_{15} \mathrm{H}\left[\mathrm{Zr}\left(\alpha_{2}-\mathrm{P}_{2} \mathrm{~W}_{17} \mathrm{O}_{61}\right)_{2}\right] \cdot 25 \mathrm{H}_{2} \mathrm{O}$ either by the formation of metal ion coordination complex or by the non-covalent interactions of the protonated amino group with the negatively charged surface of POMs, thus responsible for the activation of amide bonds towards hydrolysis. These POMs selectively cleave the C-terminal amide bond of glycylglycyl amide $\left(\mathrm{GGNH}_{2}\right)$, resulting in the formation of GG. No free glycine amide $\left(\mathrm{GNH}_{2}\right)$ was detected during the course of the reaction. 


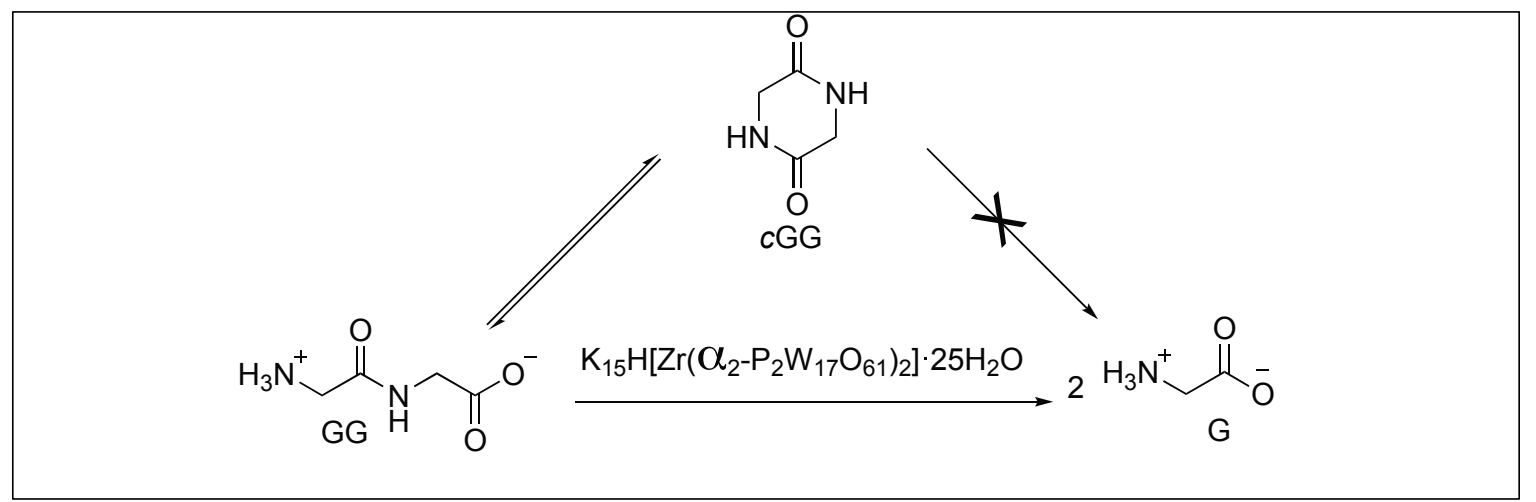

Figure 12. Peptide hydrolysis catalyzed by a polyoxometalate complex.

Recently, Vogt et al. utilized the MOF-808, a Zr(IV)-based metal-organic complex for the hydrolysis of the peptide bond in a wide range of peptides and proteins such as hen egg white lysozyme (HEWL) under physiological conditions $[81,82]$. The MOF- 88 is heterogeneous in nature and is thus a reusable catalyst. The experimental studies and calculations showed that MOF-808 hydrolyzed the Gly-Gly bond by the formation of the active complexes with two adjacent $\mathrm{Zr}(\mathrm{IV})$ centers of the $\left\{\mathrm{Zr}_{6} \mathrm{O}_{8}\right\}$ core by coordination with amide oxygen and the amine nitrogen atoms. The catalytic efficiency of MOF-808 towards the hydrolysis of peptides is dependent on the bulkiness and nature of the side chain amino acid residues. Dipeptides with small or hydrophilic residues undergo cleavage faster as compared to those with bulky and hydrophobic residues.

Asp-Xaa Selective Hydrolysis of the Peptide Bond by Oxo-Metal Ions

It has been reported that oxomolybdate(VI) catalyzes the cleavage of various peptides containing aspartic acid (Asp) with cleavage at the C-terminal side of the Asp residue. This is due to the attack of the side chain of the Asp on the amidic carbonyl which is activated by the coordination with oxomolybdate(VI), resulting in the formation of the five-membered ring and simultaneous cleavage of the amide bonds (Figure 13) [81,82].

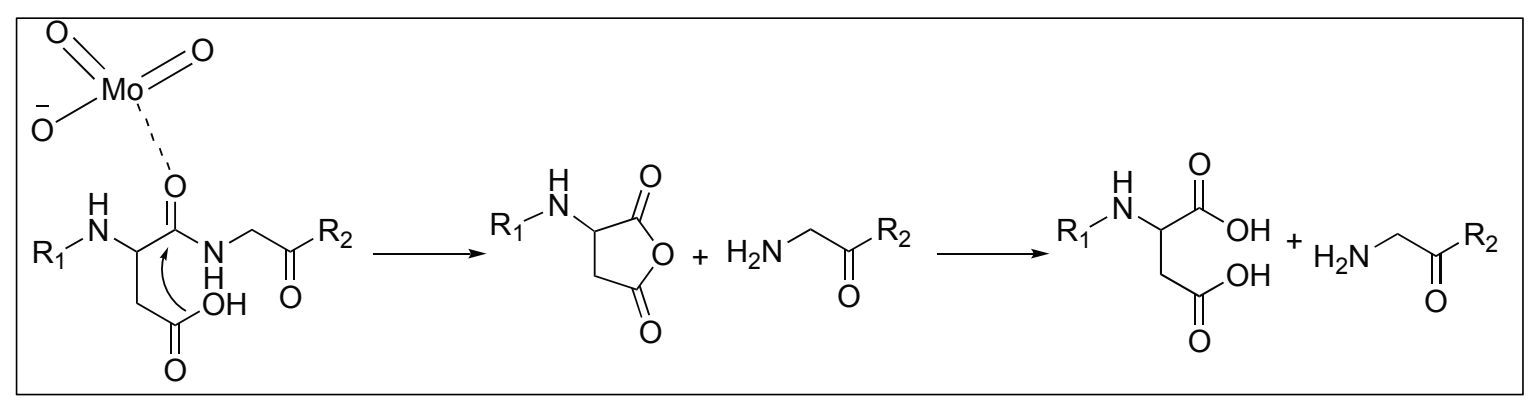

Figure 13. Oxomolybdate(VI) catalyzed cleavage of peptide bonds.

Various Other Metal Complexes

The Westheimer and Trapmann groups showed that the metal complexes containing Co(II), $\mathrm{Cu}(\mathrm{II})$, and $\mathrm{Ni}$ (II) ions cleave various dipeptides [83,84]. Out of various metal complexes, the $\mathrm{Co}$ (III) complex $\left[\mathrm{Co}(\operatorname{trien}) \mathrm{OH}\left(\mathrm{H}_{2} \mathrm{O}\right)\right]^{2+}$ is one of the widely studied metal ion complexes and carried out the rapid hydrolysis of the peptide bond [85-88]. The detailed mechanistic investigation showed that first, the metal complex $\left[\mathrm{Co}(\operatorname{trien}) \mathrm{OH}\left(\mathrm{H}_{2} \mathrm{O}\right)\right]^{2+}$ forms a tertiary complex with a dipeptide by the replacement of an equatorially coordinated water molecule in the octahedral Co(III) complex by the N-terminal amine of the peptide. This mode of coordination brings the axially bound hydroxyl group in close proximity to the peptide carbonyl resulting in the hydrolysis of the peptide bond (Figure 14). 




Figure 14. Co(III) Complex catalyzed peptide hydrolysis.

Anchoring at Cys Side Chains: Molybdocene

Erxleben et al. showed that molybdocene dichloride, $\mathrm{Cp}_{2} \mathrm{MoCl}_{2}$, cleaves the amide bond at the C-terminal side of cysteine to generate Cys-Gly from Gly-Cys-Gly [89]. The cleavage is highly selective for the $\mathrm{C}$-side of $\mathrm{Cys}$ because it leads to the formation of the favorable six-membered ring. The mechanism of this reaction is illustrated in Figure 15 [89].

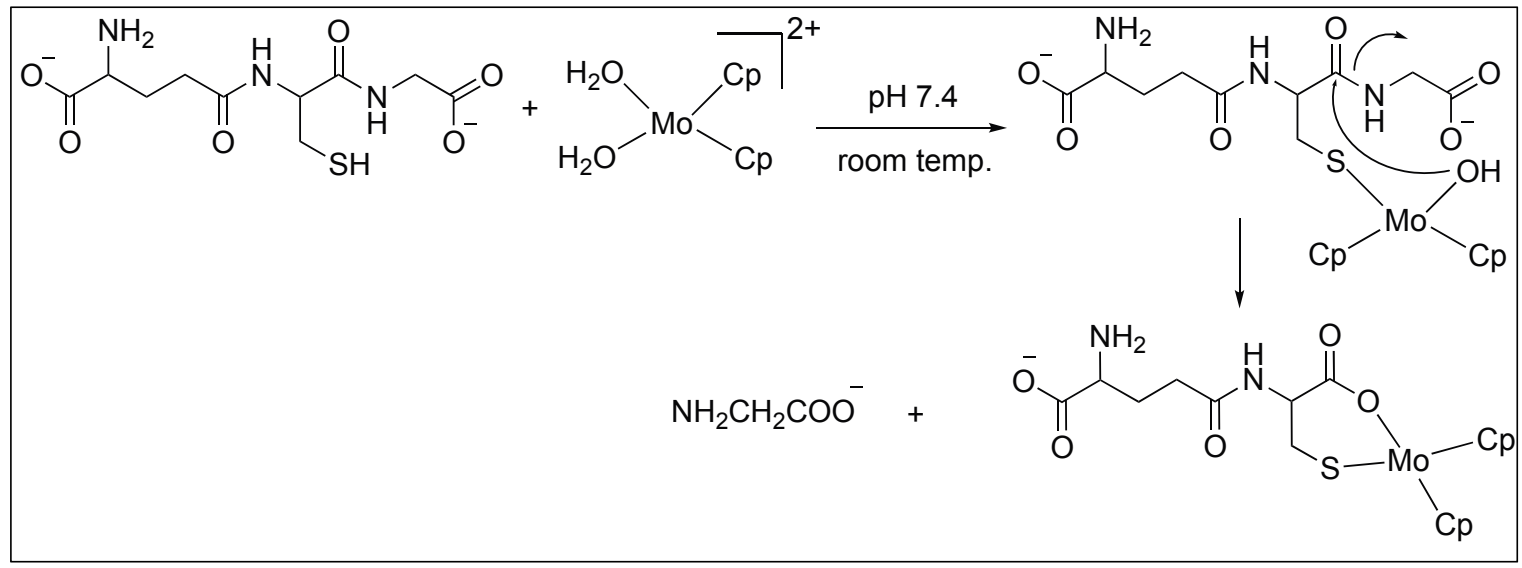

Figure 15. Mo catalyzed peptide hydrolysis.

3.1.3. Anchoring at Met, His, and Cys Side Chains: Palladium(II) Complexes for the Cleavage of Amide Bonds

Figure 16 shows the examples of platinum(II) and palladium(II) complexes which are known for the cleavage of amide bonds under mild conditions. These platinum(II) and palladium(II) complexes attach to the sulfur atom of cysteine, $S$-methylcysteine, and methionine in peptides, thus, promoting the selective cleavage of the unactivated amide bonds at the C-side of the amino acid (Figure 16) [90-92]. 




Figure 16. $\mathrm{Pd}$ and $\mathrm{Pt}$ complexes for activation of amide bonds.

Pyrazine and Pyridazine Palladium(II)-Aqua Dimers

The complete hydrolysis of the amide bonds of peptides $N$-acetylated-L-histidylglycine (Ac-L-His-Gly) and -L-methionylglycine (Ac-L-Met-Gly) at the C-terminal side of Met and His in the $\mathrm{pH}$ range $2.0<\mathrm{pH}<2.5$ was catalyzed by two dinuclear palladium(II) complexes, $\left[\{\mathrm{Pd}(\mathrm{en}) \mathrm{Cl}\}_{2}(\mathrm{l}-\mathrm{pz})\right]\left(\mathrm{NO}_{3}\right)_{2}$ and $\left[\{\mathrm{Pd}(\mathrm{en}) \mathrm{Cl}\}_{2}(\mathrm{l}-\mathrm{pydz})\right]\left(\mathrm{NO}_{3}\right)_{2}$ at $37^{\circ} \mathrm{C}$. The hydrolysis is assisted by the formation of complexes between the side chains of methionine and histidine and the metal complexes (Figure 17) [93-95].

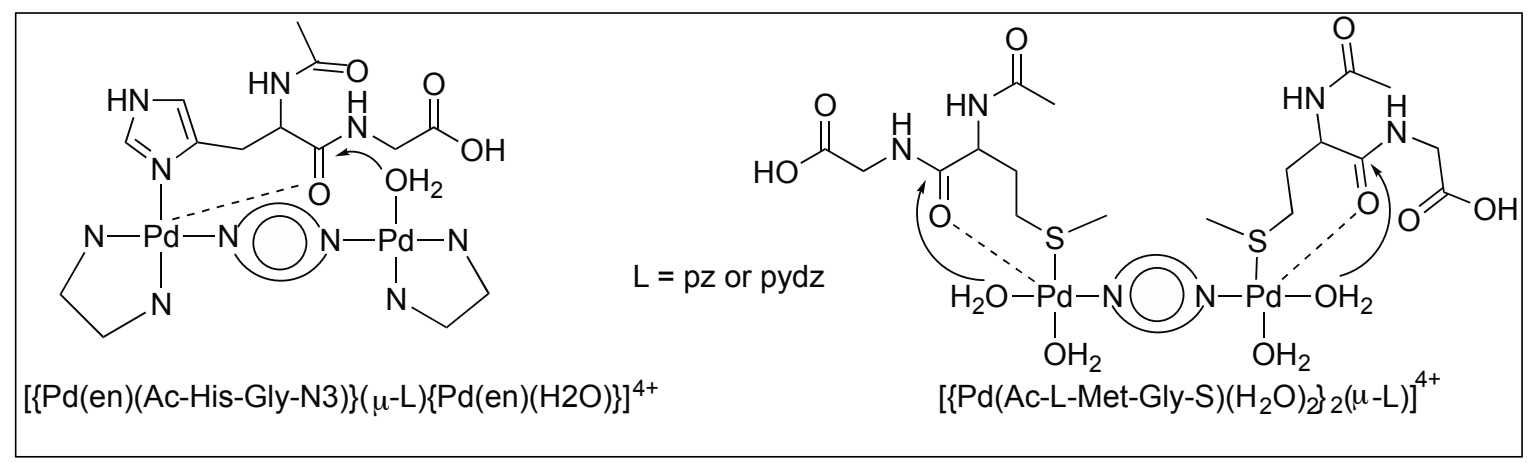

Figure 17. $\mathrm{Pd}(\mathrm{II})$ aqua dimers. 
Platinum Complexes for the Cleavage of the Amide Bond

${ }^{1} \mathrm{H}-\mathrm{NMR}$ investigation of the cleavage reactions between various $\mathrm{Pt}(\mathrm{II})$ complexes of the type $\left[\mathrm{Pt}(\mathrm{L}) \mathrm{Cl}_{2}\right]$ and $\left[\mathrm{Pt}(\mathrm{L})\left(\mathrm{CBDCA}-\mathrm{O}, \mathrm{O}^{\prime}\right](\mathrm{L}=\right.$ ethylenediamine-en; $( \pm)$-trans-1,2-diaminocyclohexane-dach; $( \pm)$-1,2-propylenediamine-1,2-pn and CBDCA is the 1,1-cyclobutanedicarboxylic anion) and the $\mathrm{N}$-acetylated-L-methionylglycine dipeptide (MeCOMet-Gly) were reported by Djuran and co-workers [93-96]. The comparison of the rate studies of these Pt complexes for the cleavage of $\mathrm{N}$-acetylated-L-methionylglycine dipeptide (MeCOMet-Gly) showed that the rate of hydrolysis decreases with the increase in the steric bulk of the CBDCA and chlorido Pt(II) complexes (en > 1,2-pn $>$ dach) (Figure 18).

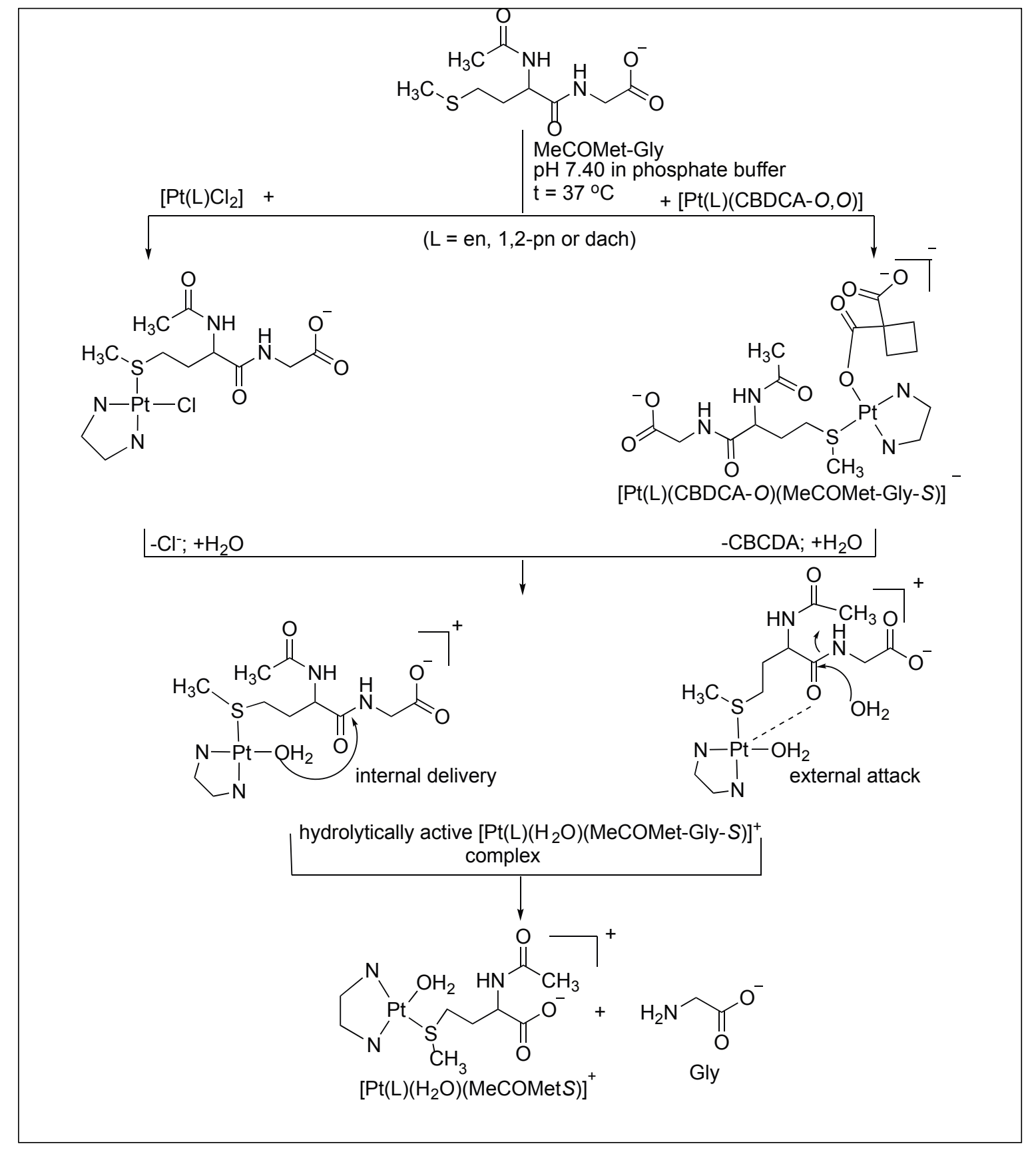

Figure 18. Hydrolytic reactions of Pt complexes. 
Later, these $\left[\mathrm{Pd}(\mathrm{en})\left(\mathrm{H}_{2} \mathrm{O}\right)_{2}\right]^{2+}$ and $\left[\mathrm{Pt}(\mathrm{en})\left(\mathrm{H}_{2} \mathrm{O}\right)_{2}\right]^{2+}$ complexes were used for the cleavage of tetrapeptide (MeCOMet-Gly-His-GlyNH $\mathrm{H}_{2}$ ) in the $\mathrm{pH}$ range of $1.5-2.0$ and at $60{ }^{\circ} \mathrm{C}$. The study showed that these complexes are highly selective for the cleavage of the amide bond at the C-terminal side of methionine (Figure 19) [97]. The high selectivity for the Met-Gly amide bond compared to the other amides is due to the high affinity of the $\mathrm{Pt}(\mathrm{II})$ and $\mathrm{Pd}(\mathrm{II})$ ions for the sulfur atom on Met. Two different mechanisms for the cleavage of tetrapeptide at the C-terminus of Met residue by $\mathrm{Pd}$ complexes have been proposed. One involves the direct coordination of the Pd complex with Met followed by the cleavage. The second involves the formation of macrochelate with both His and Met followed by the hydrolysis of the amide bond.

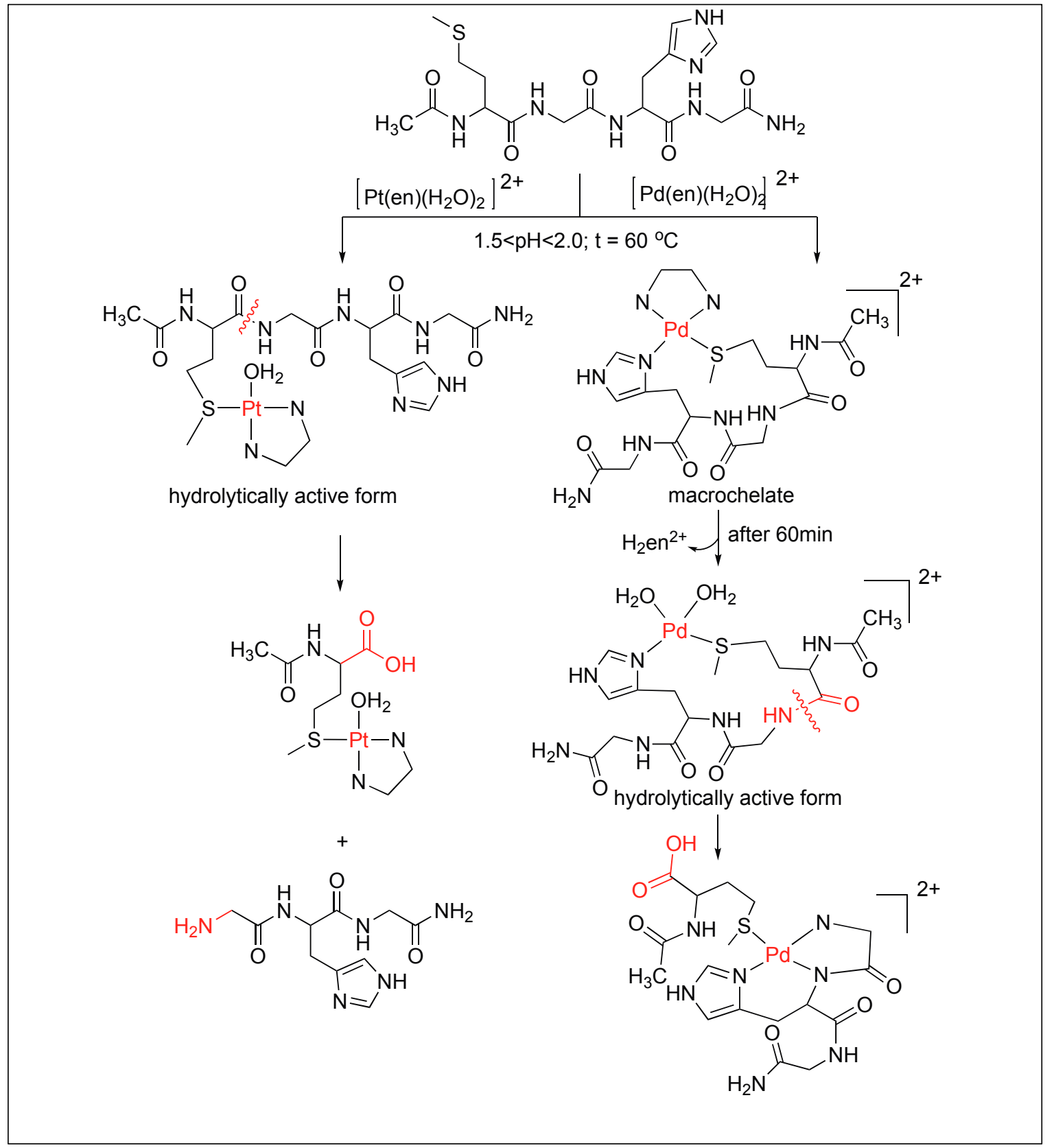

Figure 19. Hydrolytic reactions of Pd and Pt complexes.

$\mathrm{Cis}\left[\mathrm{Pd}(\mathrm{dtco})\left(\mathrm{H}_{2} \mathrm{O}\right)_{2}\right]^{2+}$ leads to the selective cleavage of the amide bond at the C-terminal of Met (Figure 20) [98]. Coordination of the metal complex promotes hydrolysis by two different mechanisms. The first involves the formation of a six-membered complex by the chelation of a metal atom with 
both the sulfur of Met and the carbonyl of the amide bond, thus, activating the amide bond toward cleavage by an external attack from water. This mechanism is favorable in the case of platinum(II) promoters and substrates with smaller anchoring side chains. Second, the mechanism involves the chelation of metal with sulfur only, followed by the internal attack of water molecules to the amide bond. This mechanism is favorable with palladium(II) promoters and substrates with longer anchoring side chains (Figure 20) [98].

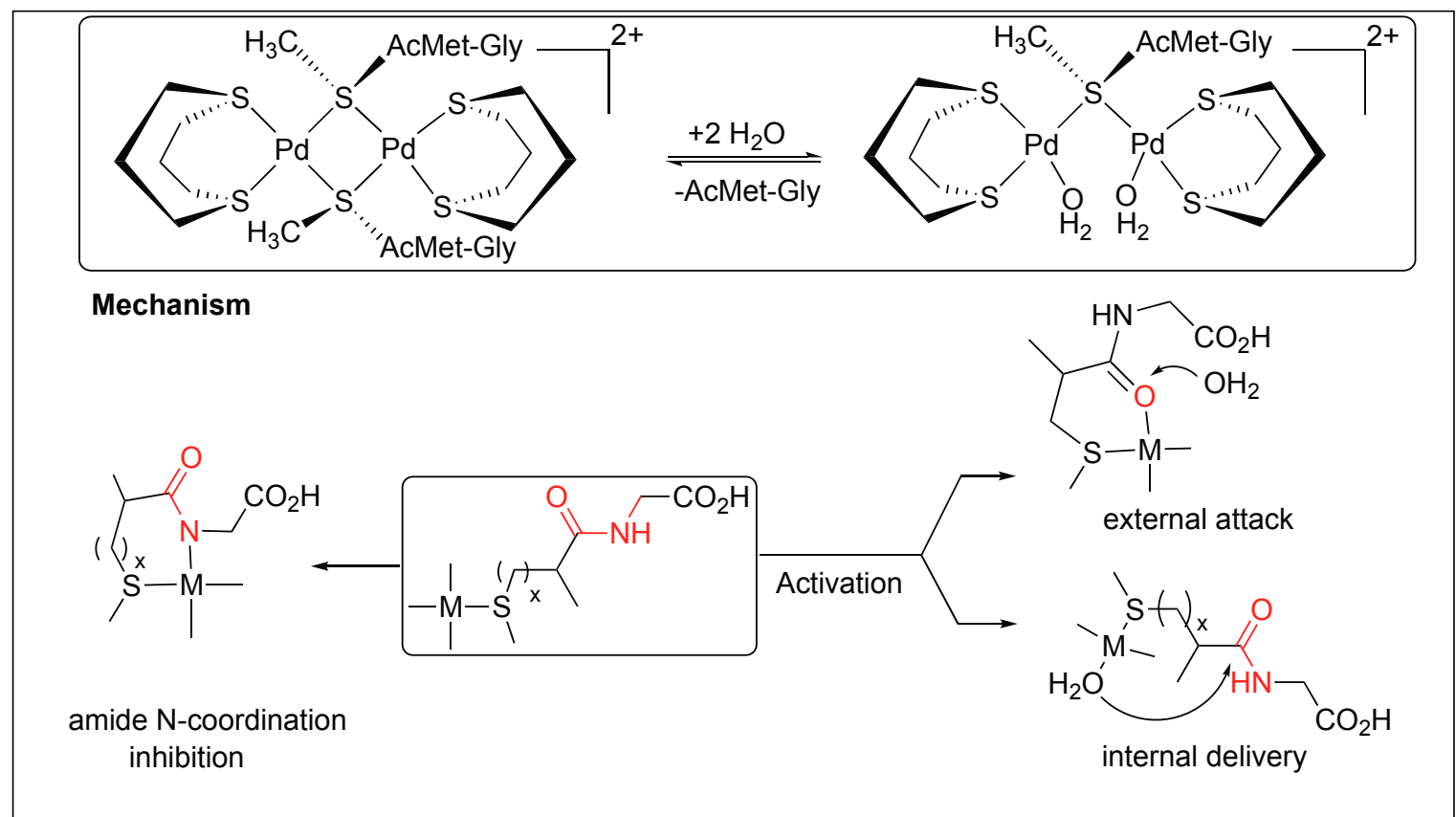

Figure 20. $\left[\mathrm{Pd}(\mathrm{dtco})\left(\mathrm{H}_{2} \mathrm{O}\right)_{2}\right]^{2+}$ mediated hydrolysis of amide bond.

Kostic et al. utilized the $\mathrm{Pd}\left(\mathrm{H}_{2} \mathrm{O}\right)_{4}$ complex for the cleavage of decapeptide (Ac-AKYGGMAARA) under acidic conditions ( $\mathrm{pH}$ 2.3) at $60{ }^{\circ} \mathrm{C}$ [99]. The cleavage of the peptide bond took place at the Gly residue next to Met on the N-terminal side and generated two fragments after $24 \mathrm{~h}$. $\mathrm{The} P d\left(\mathrm{H}_{2} \mathrm{O}\right)_{4}$ complex binds to the $S$ of the Met residue leading to the formation of two different complexes under the reaction conditions (active and inactive), which are in equilibrium with each other (Figure 21). The active complex led to the formation of two fragments through hydrolysis but the inactive complex did not undergo any hydrolysis. The coordination of two amide nitrogen atoms in the inactive complex quench the Lewis acidity of $\mathrm{Pd}(\mathrm{II})$, thus no hydrolysis was observed.

Next, Kostic et al. used this metal complex $\mathrm{Pd}\left(\mathrm{H}_{2} \mathrm{O}\right)_{4}$ for the cleavage of the amide bond under neutral conditions in different peptide substrates such as Gly-Met, Sar-Met, and Pro-Met. This study showed that the rate of hydrolysis at a neutral $\mathrm{pH}$ is slow compared to that at a low $\mathrm{pH}$ [44]. Interestingly, the complete cleavage of Sar-Met and Pro-Met was observed but no cleavage was observed for Gly-Met at a neutral $\mathrm{pH}$. This is due to the difference in the equilibrium position of the Gly-Met compared to that of Pro-Met. In Gly-Met, equilibrium is more shifted towards the inactive form at neutral $\mathrm{pH}$ due to the ability of Gly to form a strong coordinate bond with Pd. In contrast, for the peptide containing Sar-Met or Pro-Met, the equilibrium is shifted towards the hydrolytically active form because they are unable to form a strong coordination with Pd due to the tertiary amide of the Pro or Sar residue (Figure 22). 


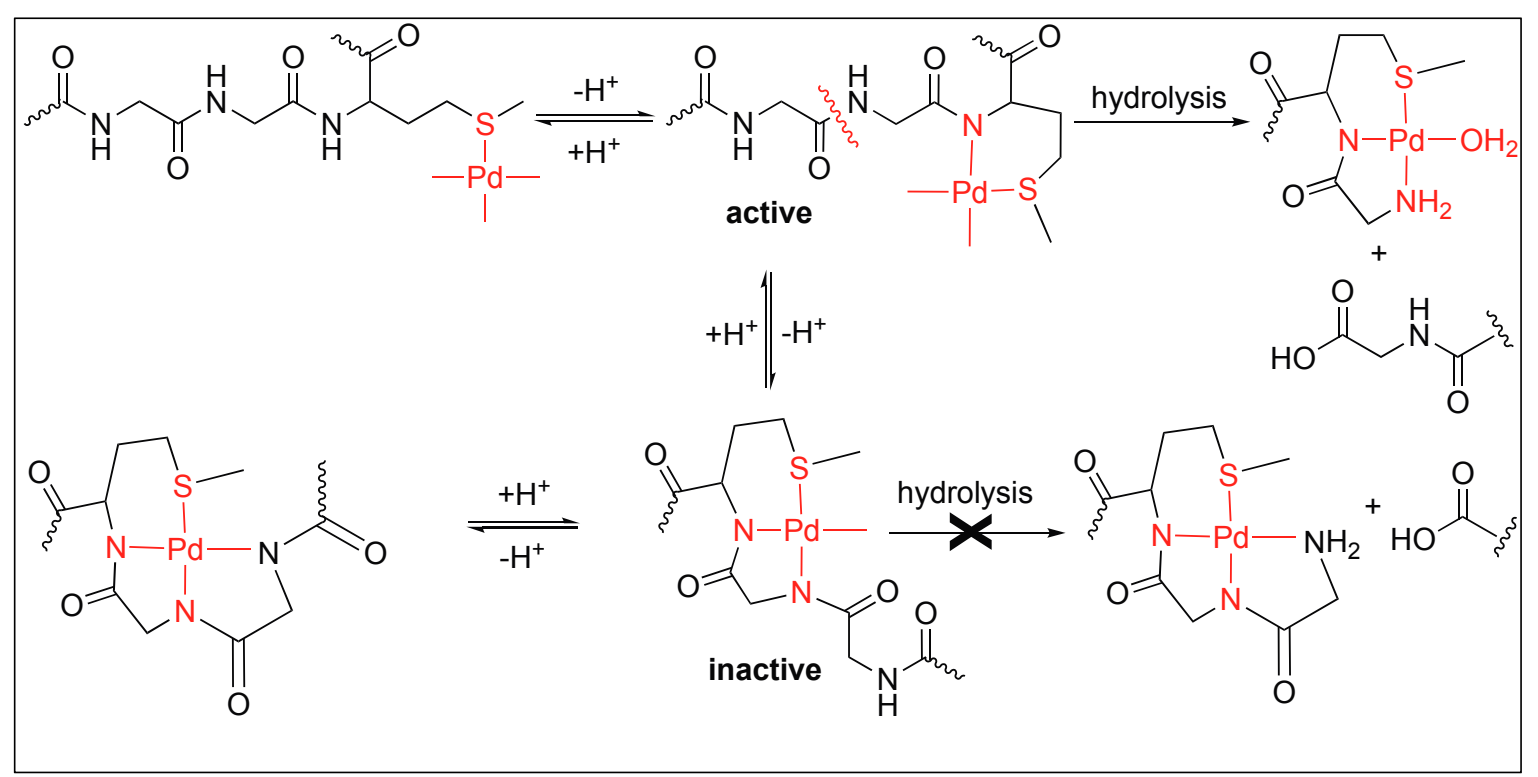

Figure 21. $\left[\mathrm{Pd}\left(\mathrm{H}_{2} \mathrm{O}\right)_{4}\right]^{2+}$ mediated hydrolysis of amide bond.

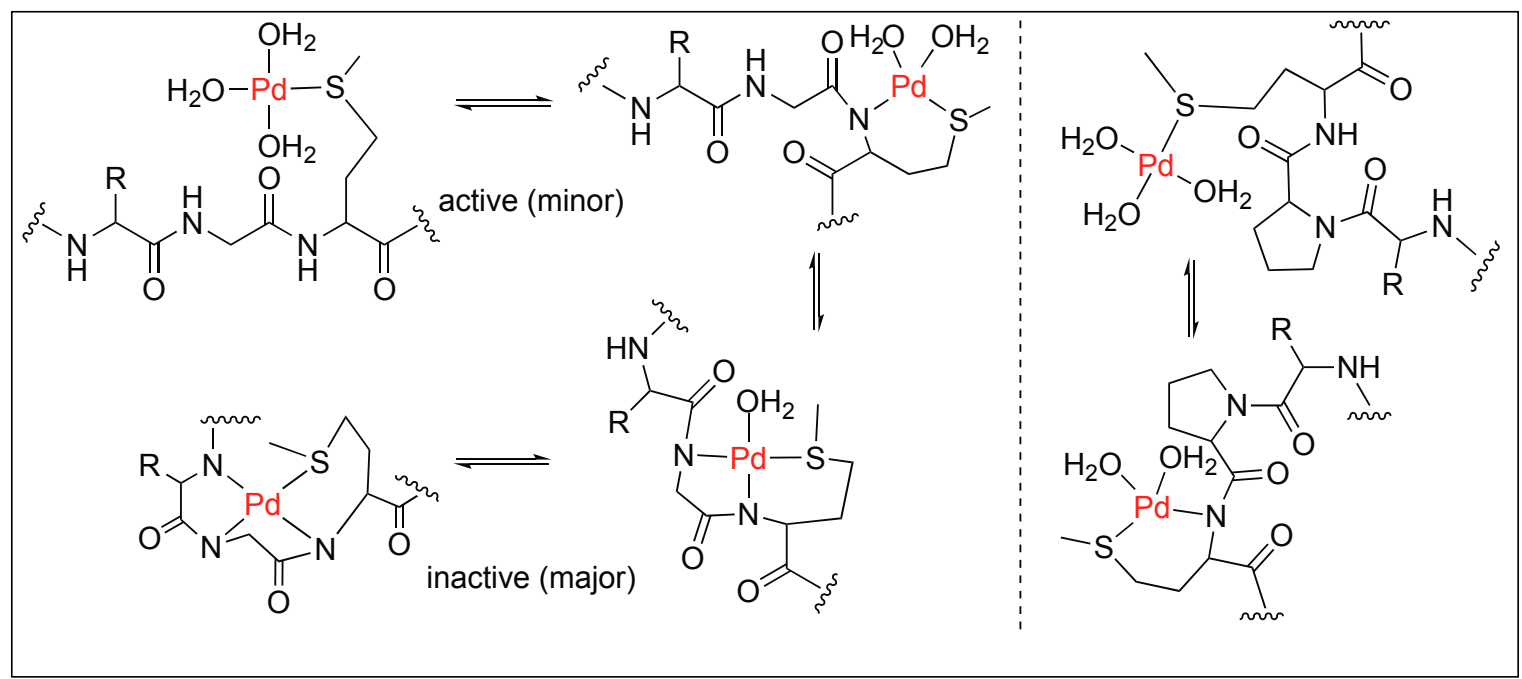

Figure 22. Pd triggered $\mathrm{pH}$ dependent hydrolysis of amide bond.

In the case of Gly-Pro-Met, the hydrolysis of the amide bond can take place either through the external or internal attack of water molecules depending upon the cis/trans conformation adopted by proline (Figure 23). The ROESY NMR studies showed that the hydrolysis of the Gly-Pro-Met peptide takes place by the external attack of water on trans-Gly-Pro [100].

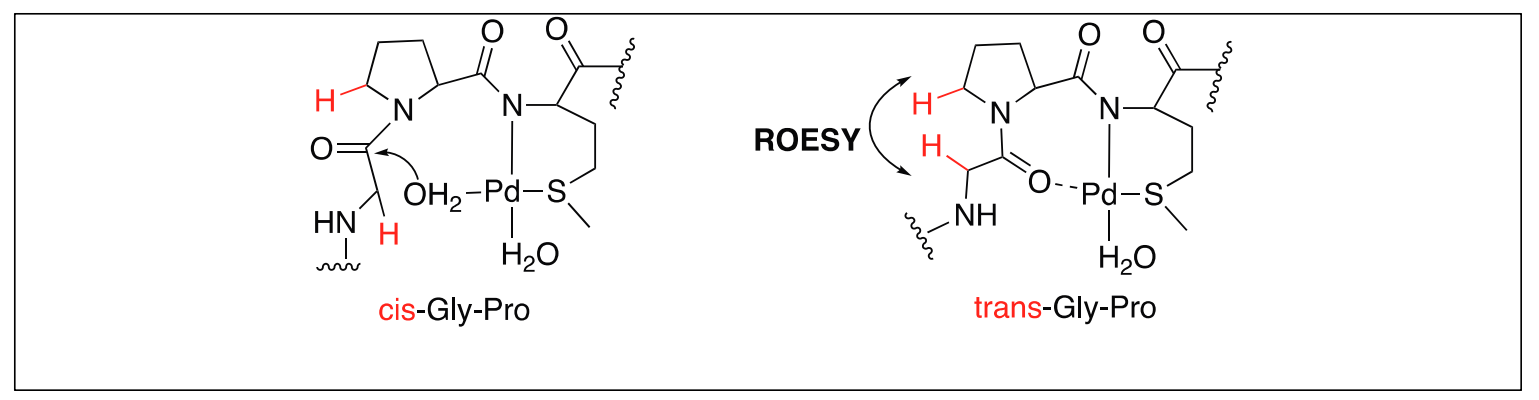

Figure 23. Cis/Trans conformations of Pd complexes. 
Overall, the $\mathrm{Pd}\left(\mathrm{H}_{2} \mathrm{O}\right)_{4}$ complex is residue selective under acidic conditions and cleaves the second amide bond upstream from the Met residue. However, the same complex is sequence-specific under neutral conditions and cleaves the amide bond only at the Pro-Met or Sar-Met residue with no cleavage observed at Gly-Met peptide (Figure 24).

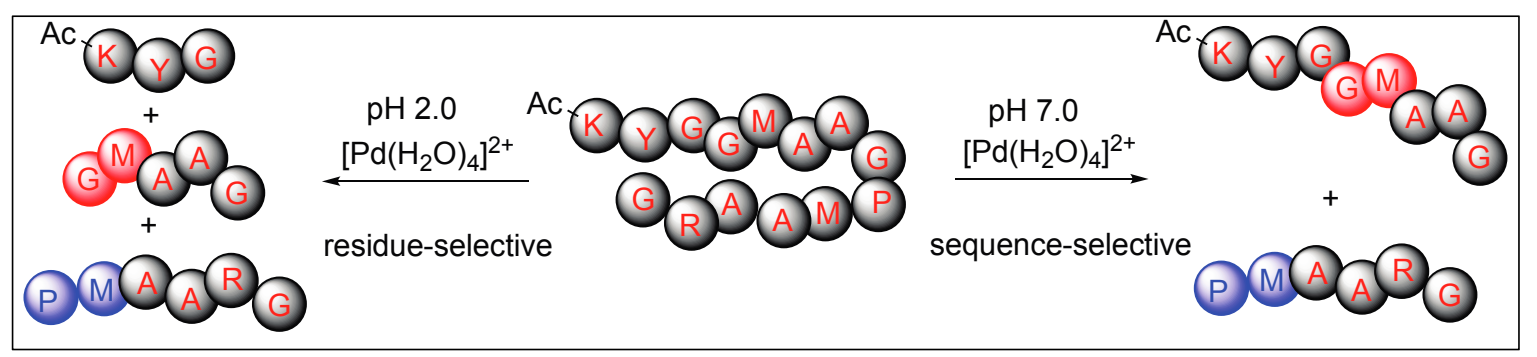

Figure 24. $\mathrm{pH}$ selective Pd catalyst for the hydrolysis.

Next, the same group utilized the $\mathrm{Pd}(\mathrm{en})\left(\mathrm{H}_{2} \mathrm{O}\right)_{2}$ complex for the acidic hydrolysis of the B-chain of bovine insulin containing two histidine residues. These complexes promoted the cleavage of the second amide bond upstream from histidine. The detailed mechanistic analysis showed the selective cleavage by the coordination of the Pd complexes with the histidine side chain and amidic nitrogen followed by the internal attack of water on the amide bond (Figure 25) [101].

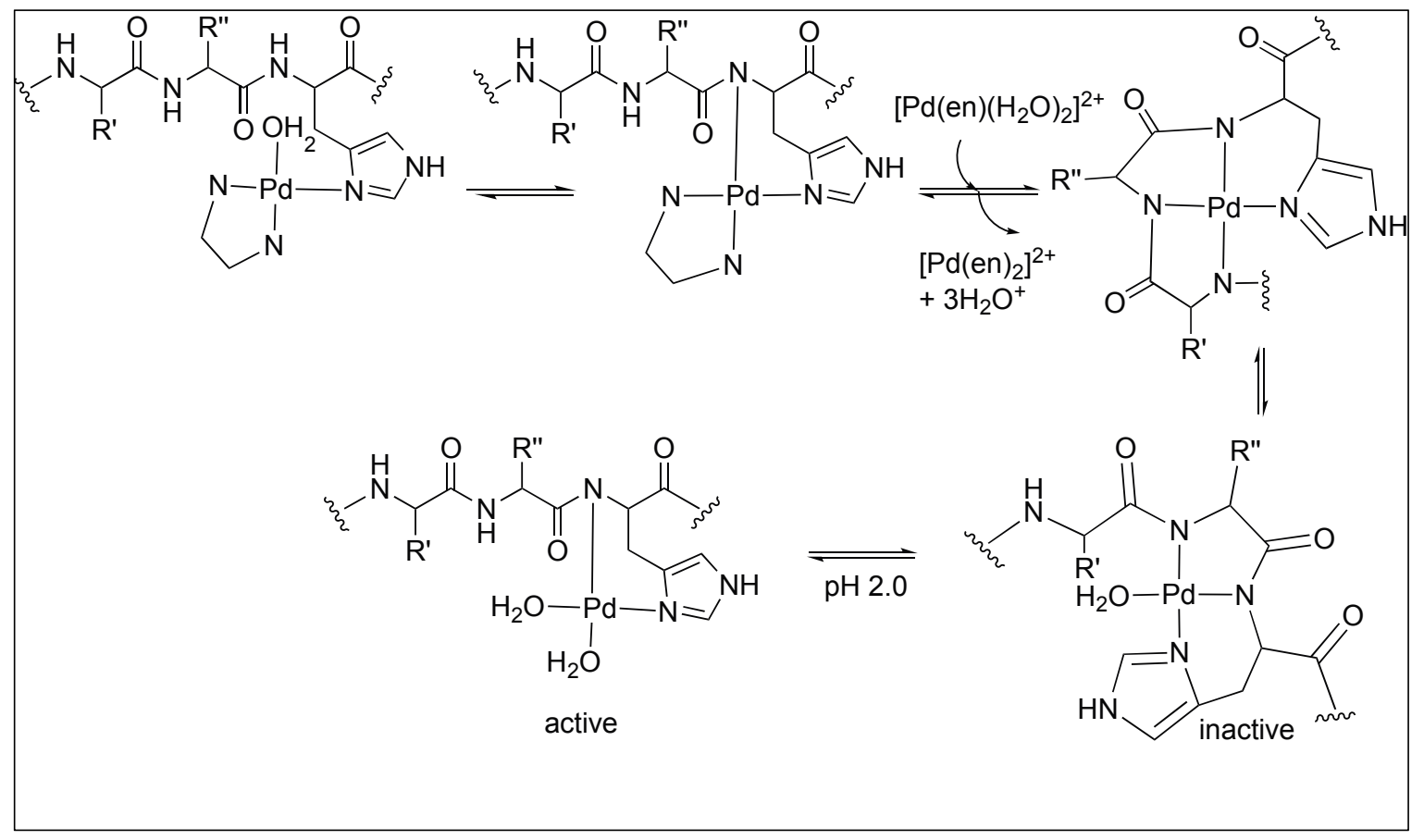

Figure 25. Acidic hydrolysis of amide bonds.

Next, they used the $\beta$-cyclodextrin Pd complex for the cleavage of the amide bond at the first amide bond upstream from the Pro-Phe sequence. The role of the $\beta$-CD complex was to bind to the hydrophobic residue (Phe) in an aqueous medium followed by the activation of the amide carbonyl group by the metal coordination, and the attack by the external water molecule leading to the cleavage of the amide bond (Figure 26) [102]. 


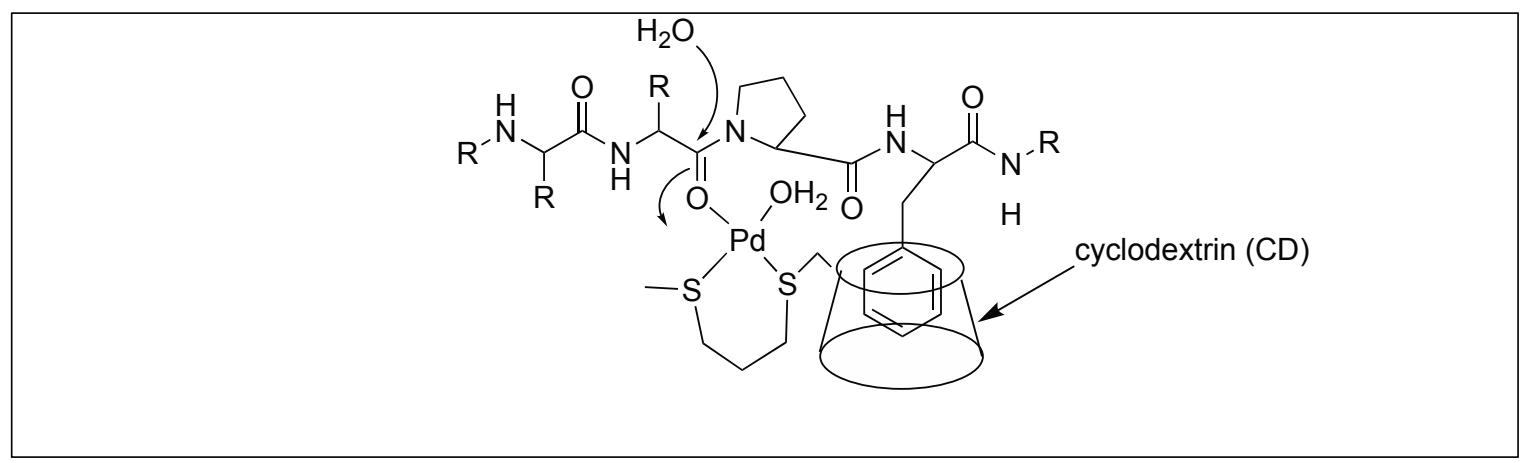

Figure 26. $\beta$-Cyclodextrin Pd-complex.

\subsubsection{Artificial Metal Proteases}

Suh et al. designed metal complexes for the cleavage of amide bonds in proteins at specific locations [103-107]. These metal complexes are highly selective with their protein partners similar to some natural proteases. They also demonstrated that the catalytic rate of hydrolysis increased by the formation of the complex between the substrate and catalyst. This is achieved by increasing the multinuclear metal centers, which provide extra metal centers as substrate binding sites. They showed that the rate of hydrolysis of the myoglobin protein increased with the increase in the number of metal centers in the mono (half-life for hydrolysis $24 \mathrm{~h}$, Figure 27), dinuclear (half-life for hydrolysis $3.5 \mathrm{~h}$ ), and tetranuclear metal centers (half-life for hydrolysis $1.3 \mathrm{~h}$ ) [103].

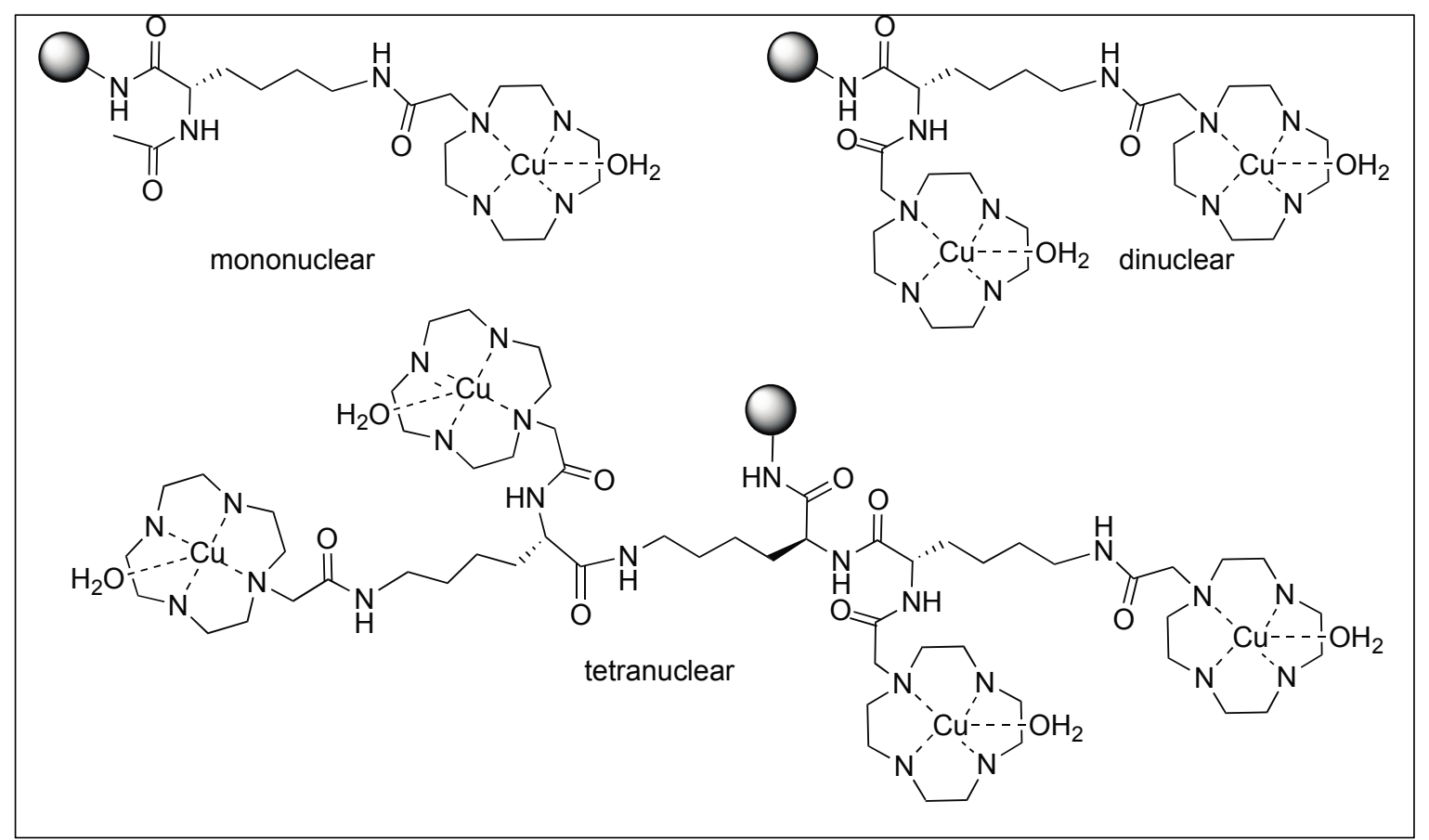

Figure 27. Artificial metal complexes with different numbers of metal centers.

They showed that the selectivity towards a specific protein was achieved by the addition of organic pendants such as peptide nucleic acid (PNA), which are responsible for selective binding to a particular protein. Overall, the goal of this research was to synthesize peptide-cleavage agents selective for the hydrolysis of pathogenic proteins responsible for Alzheimer's disease, type 2 diabetes mellitus, and Parkinson's disease. 
Aldehyde Pendant for the Cleavage of Proteins

Ammonium groups are abundant on the surface of proteins and form imine with aldehyde faster than the peptide bond cleavage and, through this process, brings the reactive metal catalytic center in close proximity to the protein/peptide chain (Figure 28). The rapid formation of imine makes the attack of the metal center on the peptide bond an intramolecular process, thus, increases the rate of hydrolysis. Based on this concept, several artificial metalloproteases have been developed by incorporating an aldehyde handle close to the metal center and has been successfully been applied for the faster cleavage of peptide bonds [104].

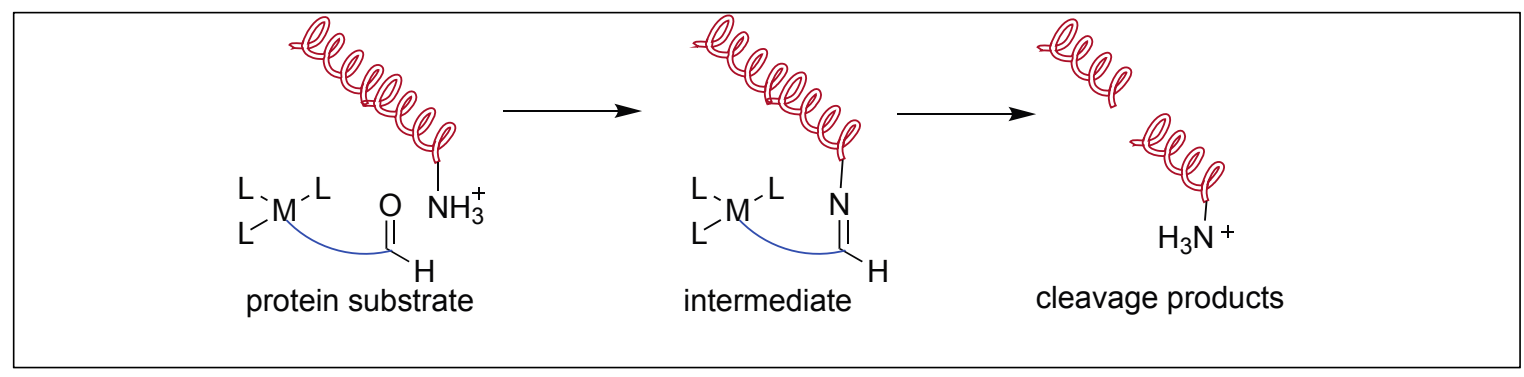

Figure 28. Aldehyde pendant mediated cleavage of peptide bonds.

\section{Mb-Selective Artificial Protease}

The catalyst for the cleavage of myoglobin $(\mathrm{Mb})$ was designed by attaching the cyclen metal complex containing $\mathrm{Cu}$ (II) or $\mathrm{Co}$ (III) to the peptide nucleic acid (PNA) monomers, which act as binding sites for the $\mathrm{Mb}$ (Figure 29) [105]. Varieties of linkers were inserted between the PNA binding site and the catalytic cyclen site for the formation of Mb-cleaving catalysts. MALDI-TOF MS showed that the cleavage of the peptide backbone chain of $\mathrm{Mb}$ takes place at Leu89-Ala90. Various chelating ligands were tested for determining the activity of the Mb-cleaving catalyst but only cyclen and its triaza-monooxo analog showed efficient catalytic activity.

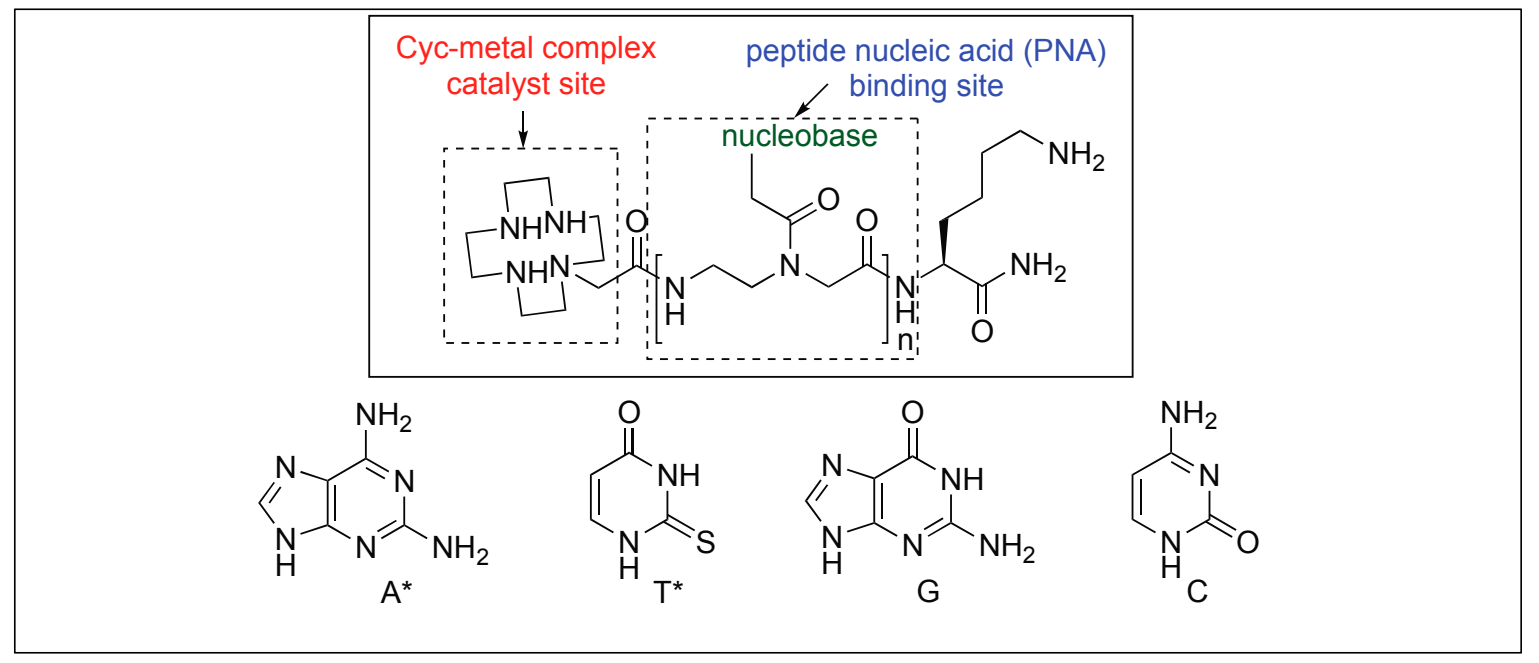

Figure 29. Catalyst design for protein cleavage.

Mechanism: The first step involves the binding of the carbonyl group of the amide to the Co(III) metal center to form a CS complex (Figure 30). The selectivity of one amide carbonyl over the rest of the amidic carbonyls is based on the other half of the catalyst, which is responsible for the recognition of a particular protein and a particular site. This $\mathrm{Co}(\mathrm{III})$ carbonyl coordination activates the amidic carbonyl for a nucleophilic attack by the hydroxide ion on the metal center, resulting in the formation of tetrahedral intermediate T. This is followed by the collapse of the tetrahedral intermediate $(\mathrm{T})$, 
resulting in the breakage of the amide bond to generate a peptide amine and corresponding peptide acid [106].

Suh and co-workers showed that the cleaving capability of the $\mathrm{Co}(\mathrm{III}) / \mathrm{Cu}$ (II) complexes of cyclen increased by the replacement of one nitrogen atom of cyclen with an oxygen atom. The Co(III)-oxacyclen complexes (1-oxa-4,7,10-triazacyclododecane $\mathrm{Co}(\mathrm{III})$ ) cleaved the proteins such as BSA, HEWL, Mb, and bovine serum-globulin with a 4-14 times higher catalytic efficiency compared to the Co(III)-cyclen complexes [106].

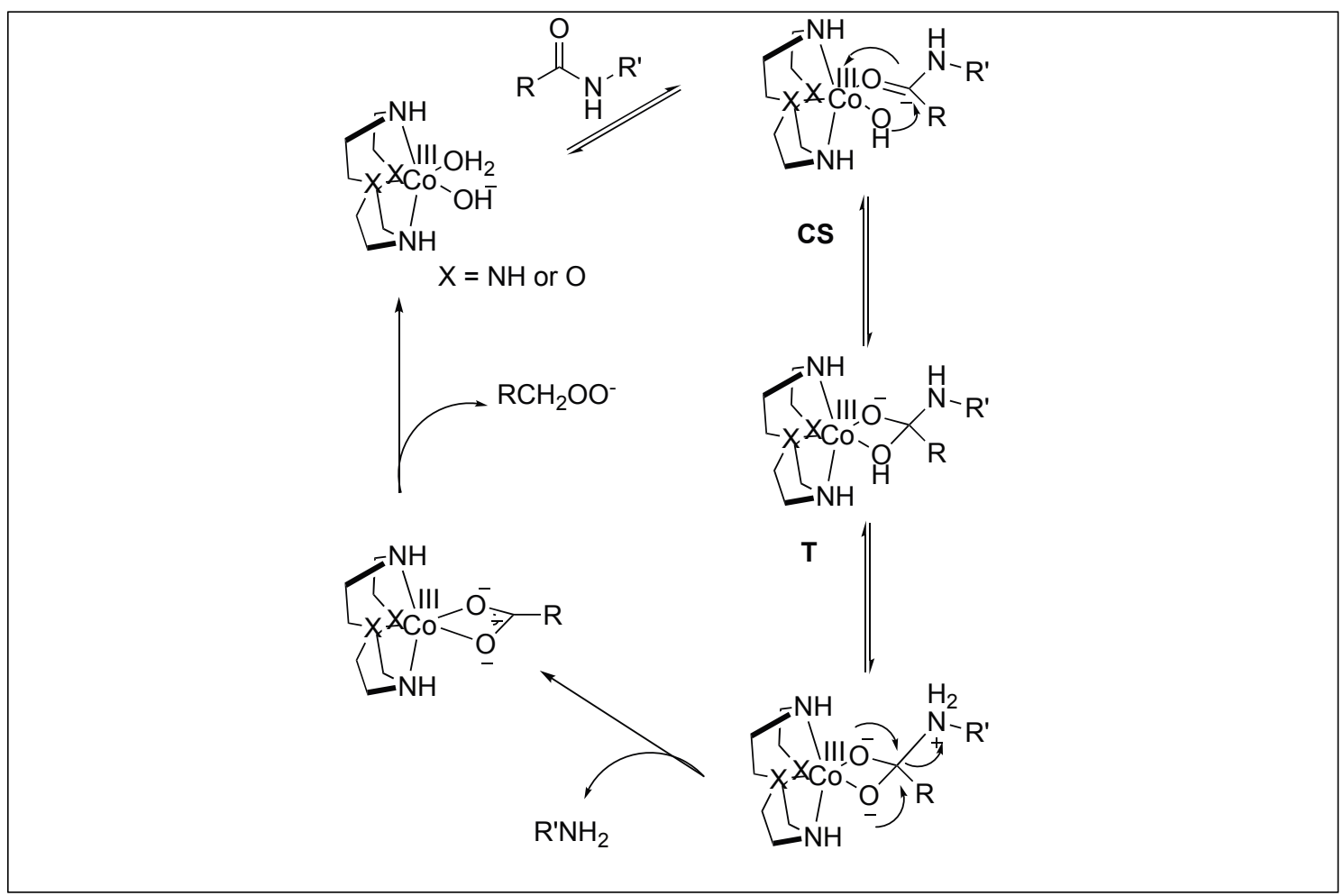

Figure 30. Mechanism of $\mathrm{Co}(\mathrm{III})$-metal complexes.

\section{PDF-Selective Artificial Protease}

The catalyst for the cleavage of the protein, peptide deformylase (PDF), was obtained in a selective manner by screening the library of catalysts (Figure 31). The catalyst cleaved the backbone peptide chain of the PDF at position Gln152-Arg153. Docking simulations showed that multiple interactions were responsible for the formation of a complex between the catalyst and PDF. Fifteen other proteins were examined, but none of them underwent cleavage by this Co(III) complex, which further confirmed the highly selective nature of these metal complexes [107].

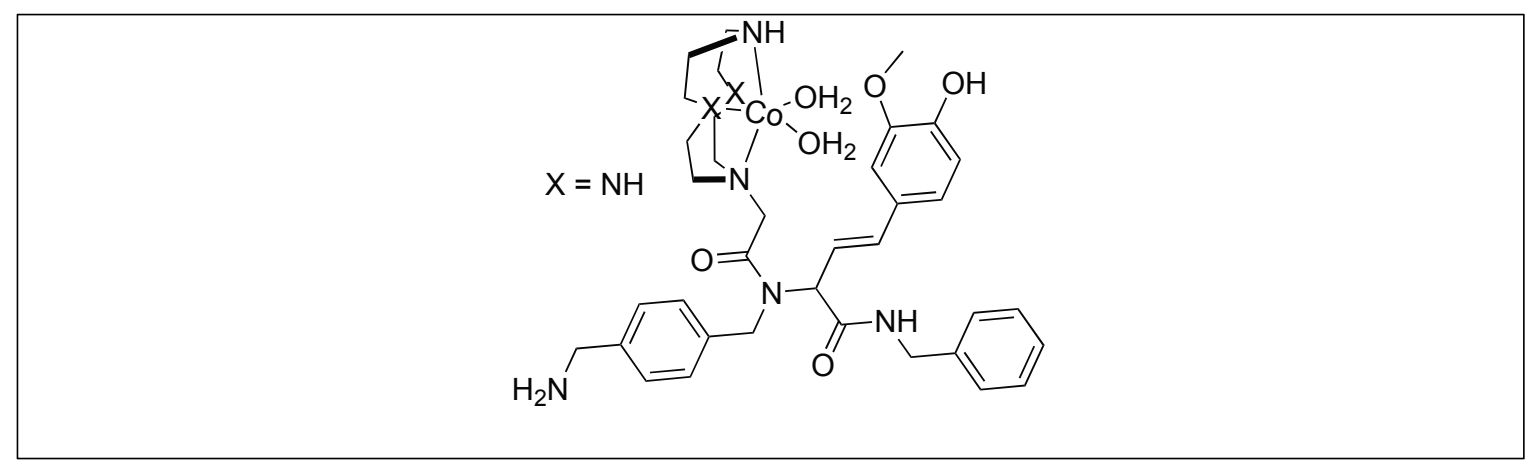

Figure 31. Metal-assisted catalyst for PDF. 


\section{AmPs-Selective Artificial Protease}

AmPs are amyloidogenic peptides or proteins which lack active sites and are related to diseases such as Alzheimer's and type 2 diabetes. Based on the above concept, Suh et al. synthesized various other metal complexes for the selective cleavage of amide bonds in these proteins. The main advantage of this work is that such amyloidogenic proteins cannot be targeted by conventional approaches due to the lack of an active site (Figure 32) [108-110].

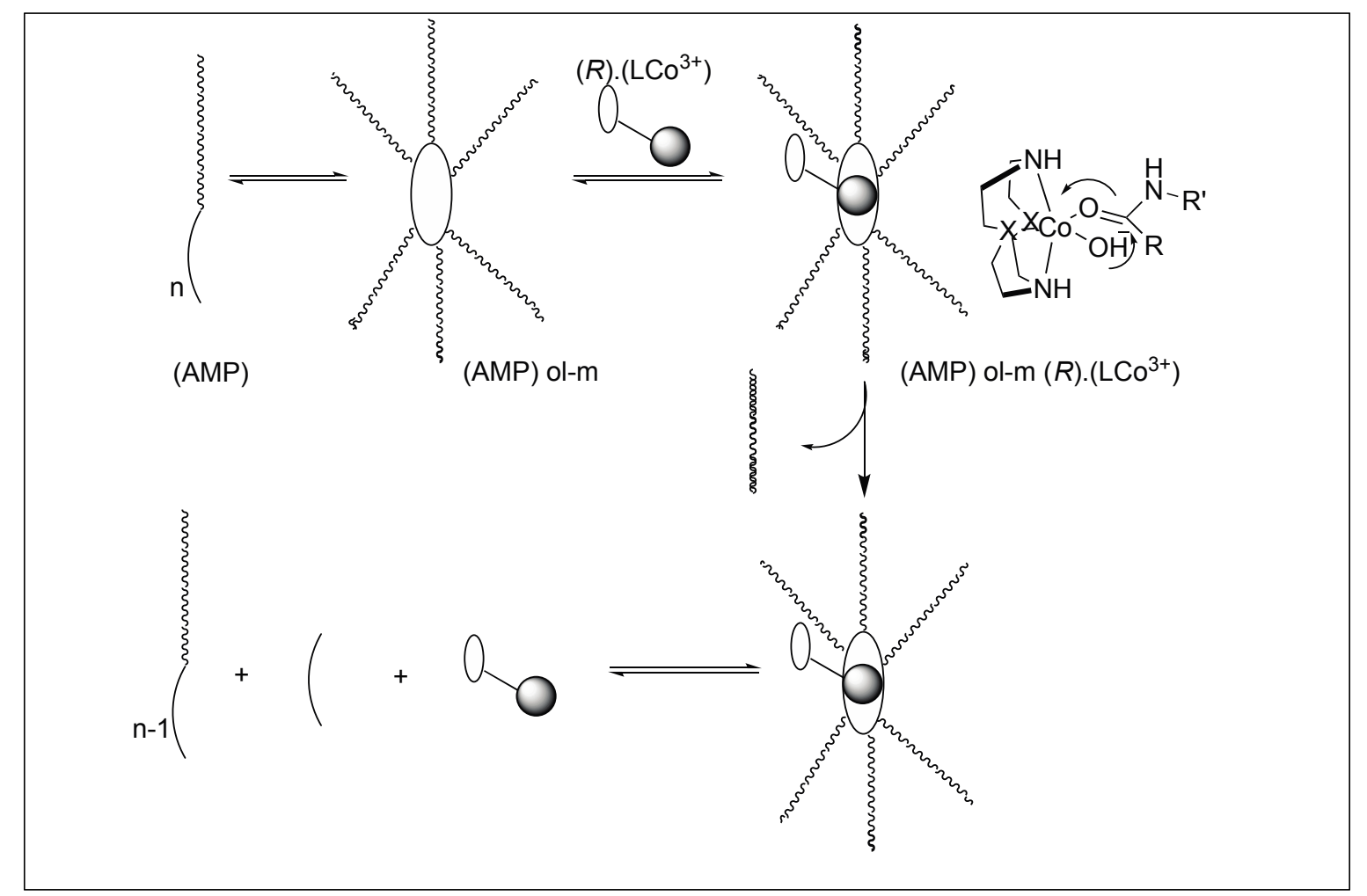

Figure 32. Metal complexes for the cleavage of amyloidgenic peptides.

Soares et al. utilized mononuclear copper(II) complexes $\left[\mathrm{Cu}\left(\mathrm{HL}^{1}\right) \mathrm{Cl}_{2}\right]$ and $\left[\mathrm{Cu}\left(\mathrm{L}^{1}\right) \mathrm{Cl}\right]$ for the cleavage of unactivated amide bonds of the proteins bovine serum albumin (BSA) and Taq DNA polymerase, under mild $\mathrm{pH}$ and temperature conditions (Figure 33). The cleavage occurred at the specific site on the solvent- exposed portions of the protein to generate particular proteolytic fragments [111].

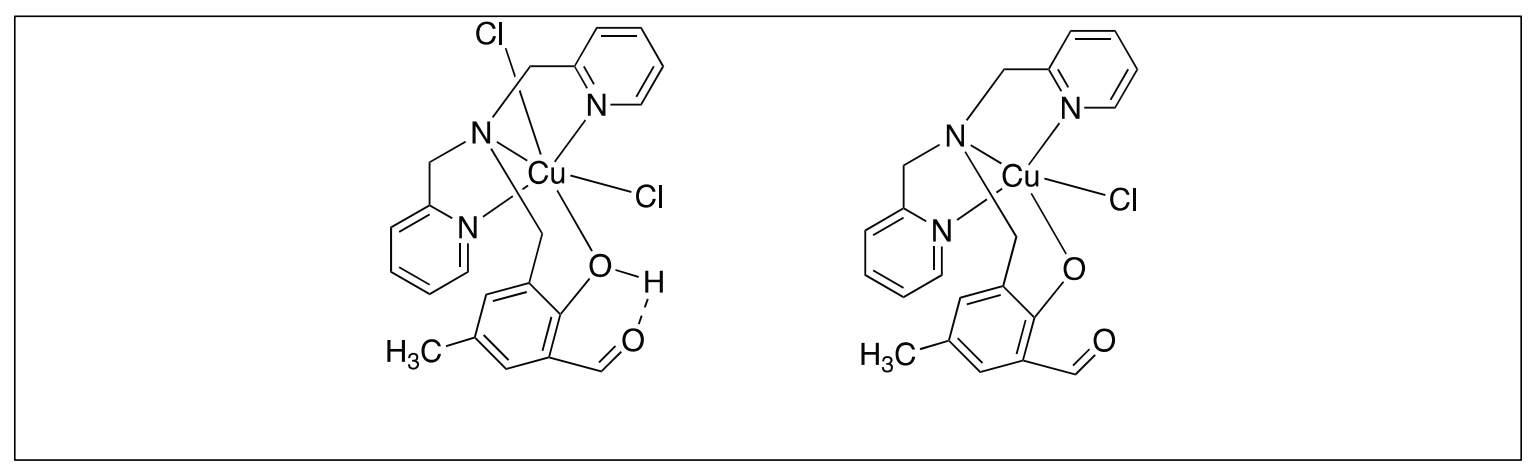

Figure 33. $\mathrm{Cu}$ complexes for activation of amide bonds. 


\subsection{The Non-Lewis Acid Reaction Mechanisms Based on the $N \rightarrow O$ Rearrangement}

In some cases, metal catalysts showed a high rate of hydrolysis of the peptide backbone chain at the N-terminus of the serine and threonine residues. Such a cleavage was catalyzed by the $\mathrm{N} \rightarrow \mathrm{O}$ rearrangement and does not employ the Lewis acid properties of the metal atom. Based on the proposed mechanism, the first step involves the formation of the $\mathrm{Ni}$ (II) complex with $4 \mathrm{~N}$ of the backbone amide chain and the side chain of the His residue with the (Ser/Thr)-Xaa-His sequence (Figure 34). The second step involves the $\mathrm{N} \rightarrow \mathrm{O}$ rearrangement from the side chain of the Ser or Thr that transfers the N-terminal R1 moiety from the peptide bond to form an ester bond. This is followed by the hydrolysis of the resulting ester, leading to the formation of two reaction products, the R1 peptide acid and the $\mathrm{Ni}(\mathrm{II})$ complex with the peptide [112,113].

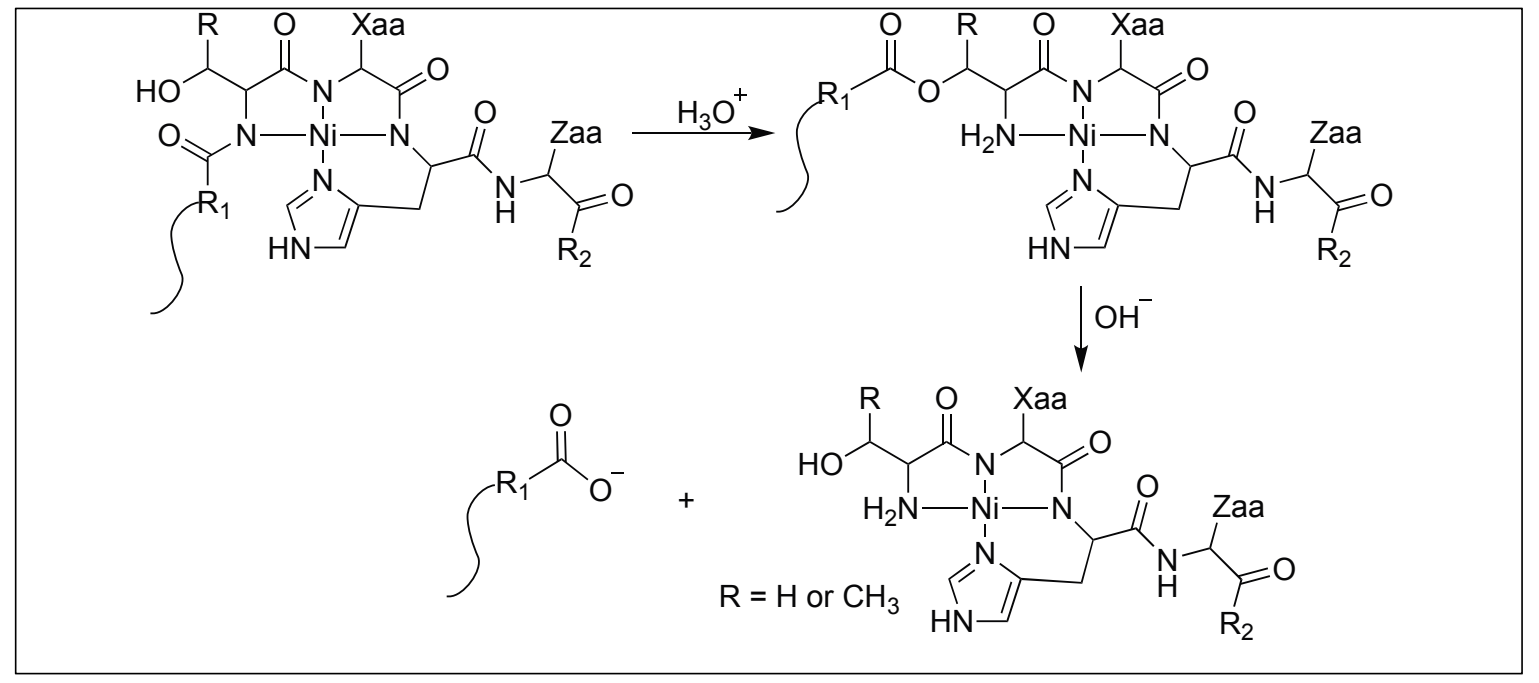

Figure 34. Non lewis acid mediated N, O Acyl rearrangement.

Scandium(III) Triflate-Promoted Serine/Threonine Selective Peptide Bond Cleavage

Kanai et al. reported the hydrolysis of the peptide bond at the N-terminus of Ser/Thr residue by using scandium triflate. This chemical cleavage relies on Sthe c triflate mediated $\mathrm{N}$ to $\mathrm{O}$ acyl rearrangement followed by the subsequent hydrolysis of the ester by heating it at $80-100{ }^{\circ} \mathrm{C}$ (Figure 35). Complete hydrolysis took place in 18-20 h. The authors have used this approach for the cleavage of various peptides including posttranslationally modified (PTM) peptides and the cleavage of native protein A $\beta 1-42$, which is closely related to Alzheimer's disease [114].

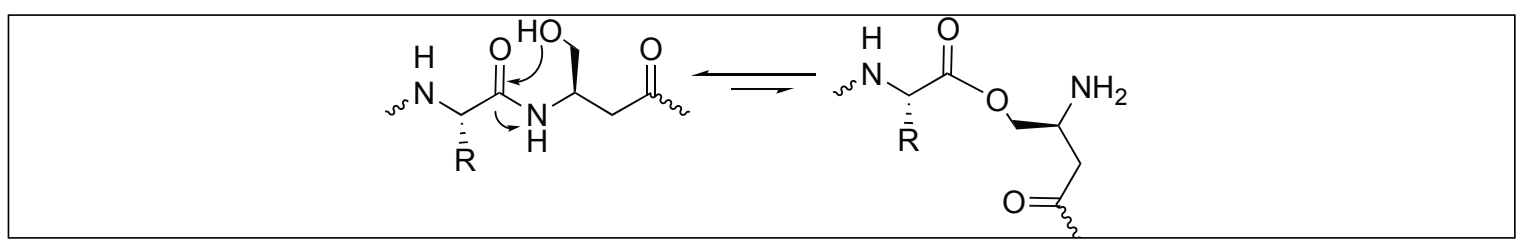

Figure 35. N, O Acyl rearrangement.

\section{Organic Molecules for Activation of Amide Bonds}

We have summarized different kinds of nonmetal-based methods, their mechanisms of hydrolysis of unactivated peptide bonds and the point of cleavages in Table 3. 
Table 3. Organic molecules based hydrolysis of peptide bonds.

\begin{tabular}{|c|c|c|c|c|}
\hline Entry & Organic Molecules & Method of Hydrolysis & Point of Cleavage & Ref. \\
\hline 1 & $\begin{array}{l}\text { Phenyl } \\
\text { isothiocyanate }\end{array}$ & $\begin{array}{l}\text { Through } 5 \text { membered cyclic } \\
\text { phenylisothiocyanate intermediate }\end{array}$ & $\begin{array}{l}\text { N-terminal side } \\
\text { of peptide }\end{array}$ & [115] \\
\hline 2 & Cyanogen bromide & Through 5 membered iminolactone & C-terminal side of Met & [116] \\
\hline 3 & $\begin{array}{l}\text { 2-Nitro-5-thiocyano } \\
\text { benzoic acid }\end{array}$ & Through 5 membered thialactone & N-terminal side of Cys & [117] \\
\hline 4 & 2-iodosobenzoic acid & Through iminospirolactone & C-terminal side of $\operatorname{Trp}$ & {$[118,119]$} \\
\hline 5 & ТВC & Through Oxindole & C-terminal side of Trp & {$[118,119]$} \\
\hline 6 & $\mathrm{~N}$-amidination & Through 5 membered cyclic amidine ring & $\begin{array}{l}\text { N-terminal side } \\
\text { of peptide }\end{array}$ & [120] \\
\hline 7 & $\begin{array}{l}\text { Protecting goups } \\
\quad \text { (Table 4) }\end{array}$ & Lactonization strategy & $\begin{array}{l}\text { C-terminal side } \\
\text { of peptide }\end{array}$ & [121-127] \\
\hline 8 & $\begin{array}{l}\mathrm{H}_{2} \mathrm{O}_{2} \text { responsive } \\
\text { protecting groups }\end{array}$ & Lactonization strategy & $\begin{array}{l}\text { C-terminal side } \\
\text { of peptide }\end{array}$ & [128] \\
\hline 9 & PyBroP & $\begin{array}{l}\text { Glutamic acid selective activation through } \\
\text { pyroglutamyl imide }\end{array}$ & N-terminal side of Glu & {$[129,130]$} \\
\hline 10 & DIB & $\begin{array}{l}\text { Hofmann rearrangement mediated } \\
\mathrm{N} \text {-acylurea intermediate }\end{array}$ & N-terminal side of Asn & [131] \\
\hline 11 & DSC & Cyclic urethane amide activation & $\begin{array}{l}\text { N-terminal side of Ser, } \\
\text { Thr, Cys and Glu }\end{array}$ & [132-136] \\
\hline 12 & $o$-NBnoc & $\begin{array}{l}\text { A photo responsive amide cleavage } \\
\text { through succinimide ring }\end{array}$ & C-terminal side of Asn & [137-142] \\
\hline 13 & $\begin{array}{l}\text { Cu-organo radical } \\
\text { conjugate }\end{array}$ & $\begin{array}{l}\text { Aerobic chemoselective oxidation of Ser } \\
\text { followed by oxalimide formation }\end{array}$ & N-terminal side of Ser & [143] \\
\hline 14 & $\mathrm{TFA} / \mathrm{H}_{2} \mathrm{O}$ & $\mathrm{N}$-acyl group mediated oxazolinium specie & $\begin{array}{l}\text { C-terminal side } \\
\text { of peptide }\end{array}$ & [144] \\
\hline 15 & Hydrazine hydrate & $\begin{array}{l}\text { Hydrazinolysis accelarated by addition of } \\
\text { ammonium salts }\end{array}$ & N-terminal of peptide & [145] \\
\hline 16 & N-Mecysteine & Through oxazolinium ion & $\begin{array}{l}\text { C-terminal side } \\
\text { of } N \text {-MeCys }\end{array}$ & [146] \\
\hline 17 & Acylated N-MeAib & Through oxazolinium ion & $\begin{array}{l}\text { C-terminal side } \\
\text { of } N \text {-MeAib }\end{array}$ & [147] \\
\hline
\end{tabular}

\subsection{N-Terminal Cleavage of Amide Bonds}

\subsubsection{Edman's Degradation}

This approach utilizes phenyl isothiocyanate for the cleavage of the peptide bond at the N-terminus. Phenyl isothiocyanate reacted with an uncharged N-terminal amino group, under mildly alkaline conditions, to form a cyclic phenylisothiocyanate derivative, which undergoes cleavage as a thiazolinone derivative under acidic conditions (Figure 36). We proposed that the activation of an amide bond is due to the formation of the five-membered cyclic phenylisothiocyanate intermediate which creates a twist in the amide bond, thus preventing the amidic nitrogen from forming a resonating structure and making it susceptible towards hydrolysis [115]. 


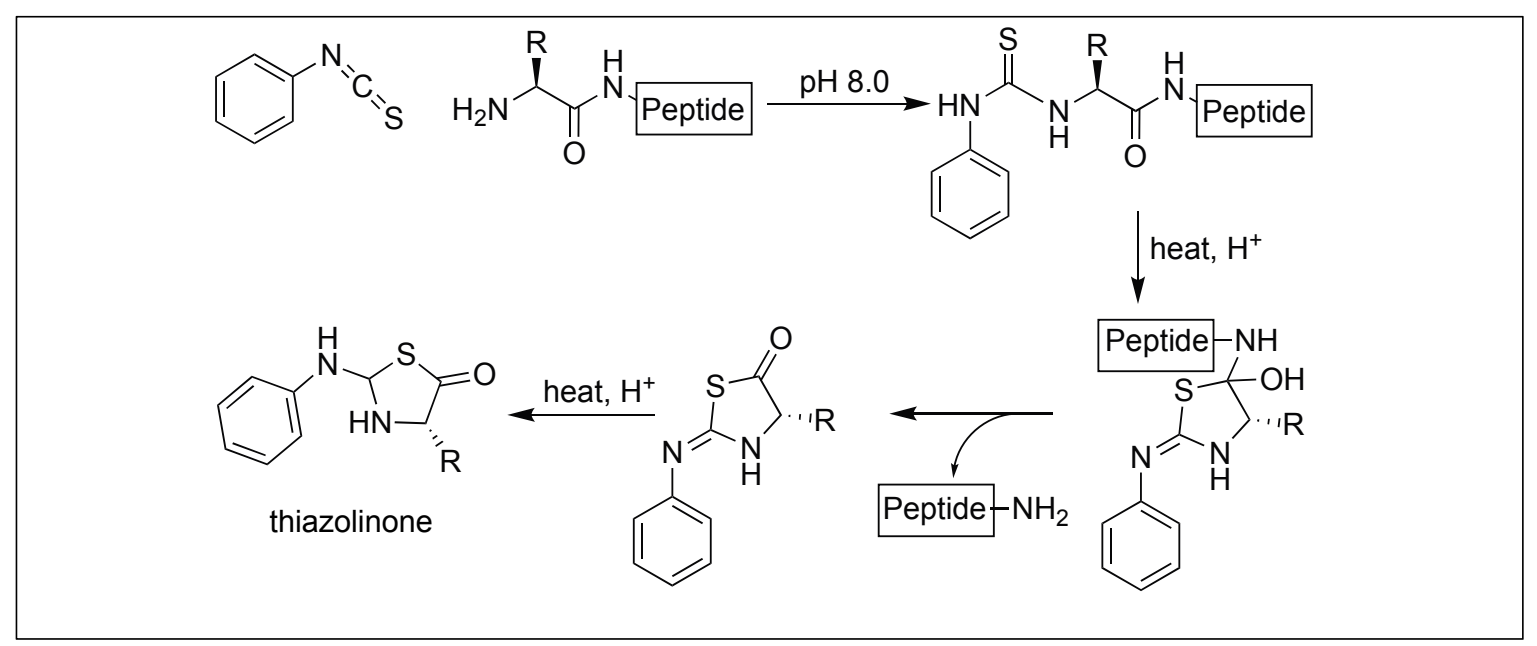

Figure 36. Edman's degradation approach for cleavage of peptide bonds.

\subsubsection{Cyanogen Bromide for Cleavage at Met Residue}

Cyanogen bromide led to the cleavage of the peptide bond at the C-terminus of the methionine residue in a selective manner. The first step involves the nucleophilic attack of the sulfur of methionine on cyanogen bromide (Figure 37) [116]. This displaces the bromide from cyanogen bromide, followed by the attack of the amide carbonyl on the cyano group, resulting in the formation of the five-membered ring, iminolactone, comprising a double bond in the ring between nitrogen and carbon. This double bond results in a rigid ring conformation, thus activating the amide bond towards cleavage at the C-terminus of Met, resulting in the generation of homoserine lactone. This approach has widely been utilized for the sequencing of proteins [116].

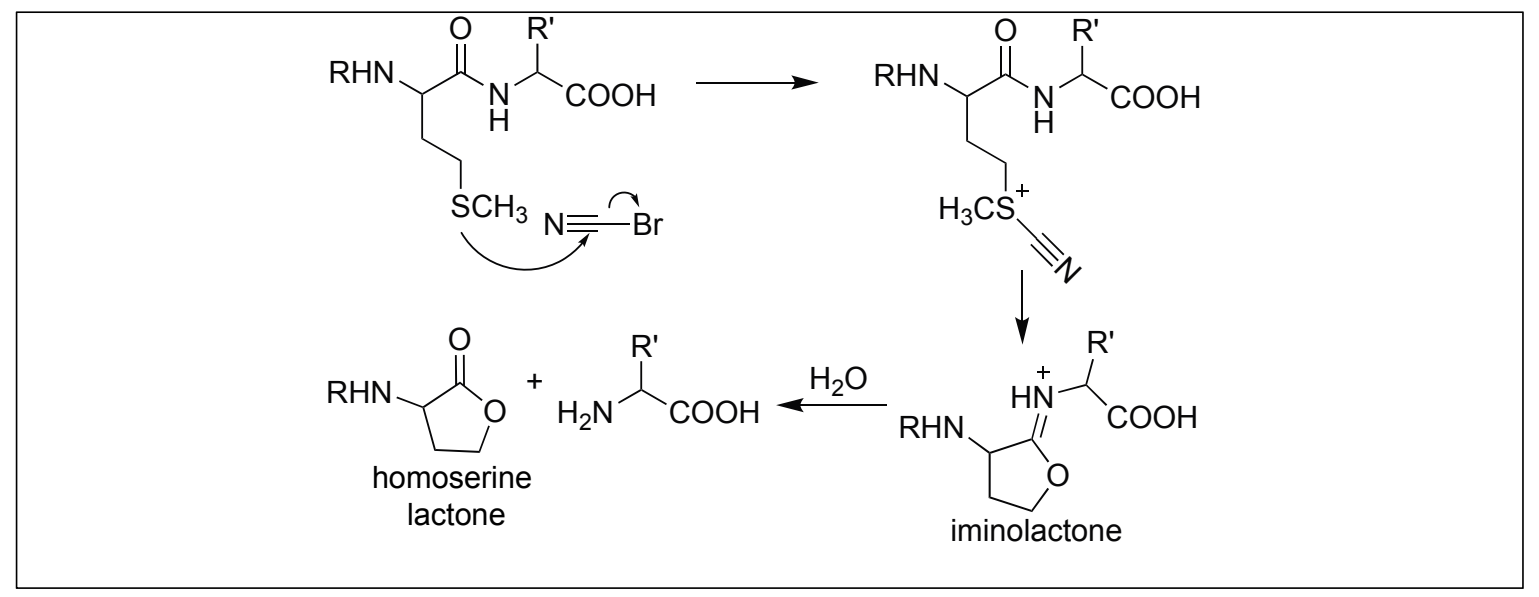

Figure 37. Cyanogen bromide for selective cleavage at Met.

\subsubsection{2-Nitro-5-Thiocyano Benzoic Acid for Cleavage at Cys}

2-Nitro-5-thiocyano benzoic acid led to the hydrolysis of the amide bond at the N-terminal side of the cysteine residue. The first step is the cyanylation of the side chain of cysteine on a peptide by 2-nitro-5-thiocyano benzoic acid, which is followed by the attack of the cysteine amidic nitrogen to the cyano group on the side-chain of cysteine, resulting in the formation of the 5-membered thiolactone ring. This, in turn, activates the amide bond towards hydrolysis under basic conditions (Figure 38). This is again due to the inability of cysteine amidic nitrogen in a thiolactone to form a resonating structure with the carbonyl of peptide bond [117]. 


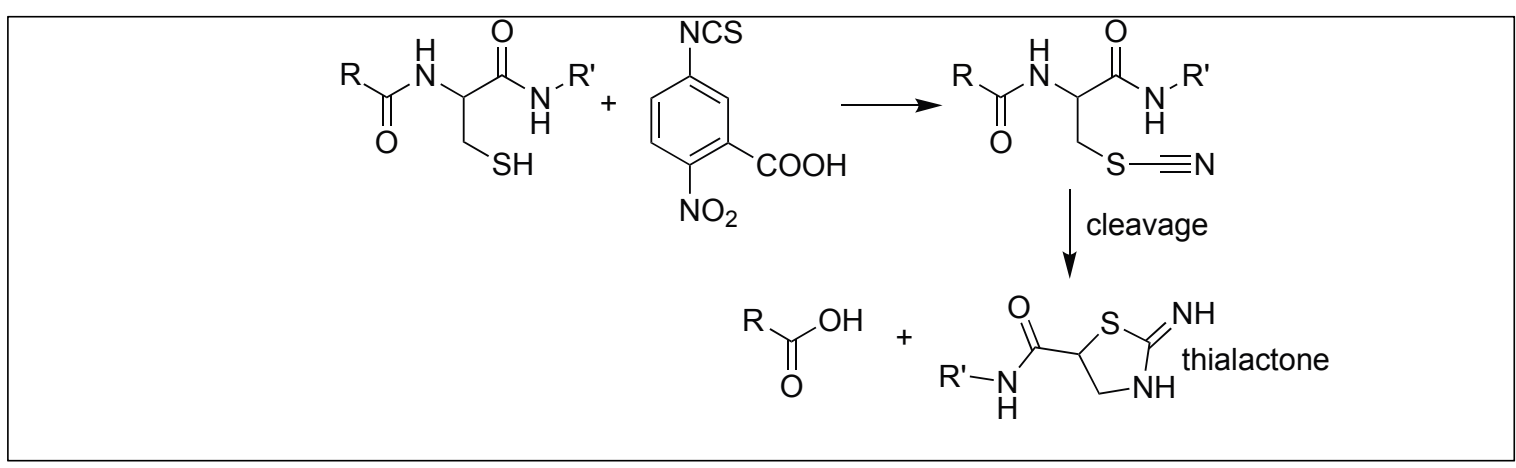

Figure 38. 2-nitro-5-thiocyano benzoic acid selective cleavage at Cys.

\subsubsection{2-Iodosobenzoic Acid for Cleavage at Trp}

2-Iodosobenzoic acid has been used for the hydrolysis of the amide bond at the C-terminal side of the Trp residue. The mechanism of the cleavage is a two-step process. The first step involves the oxidation of the side-chain of tryptophan by 2-iodosobenzoic acid followed by the nucleophilic attack from the neighboring carbonyl group of the amide bond, leading to the formation of an iminospirolactone which hydrolyzes the peptide chain in the presence of water (Figure 39) $[118,119]$.

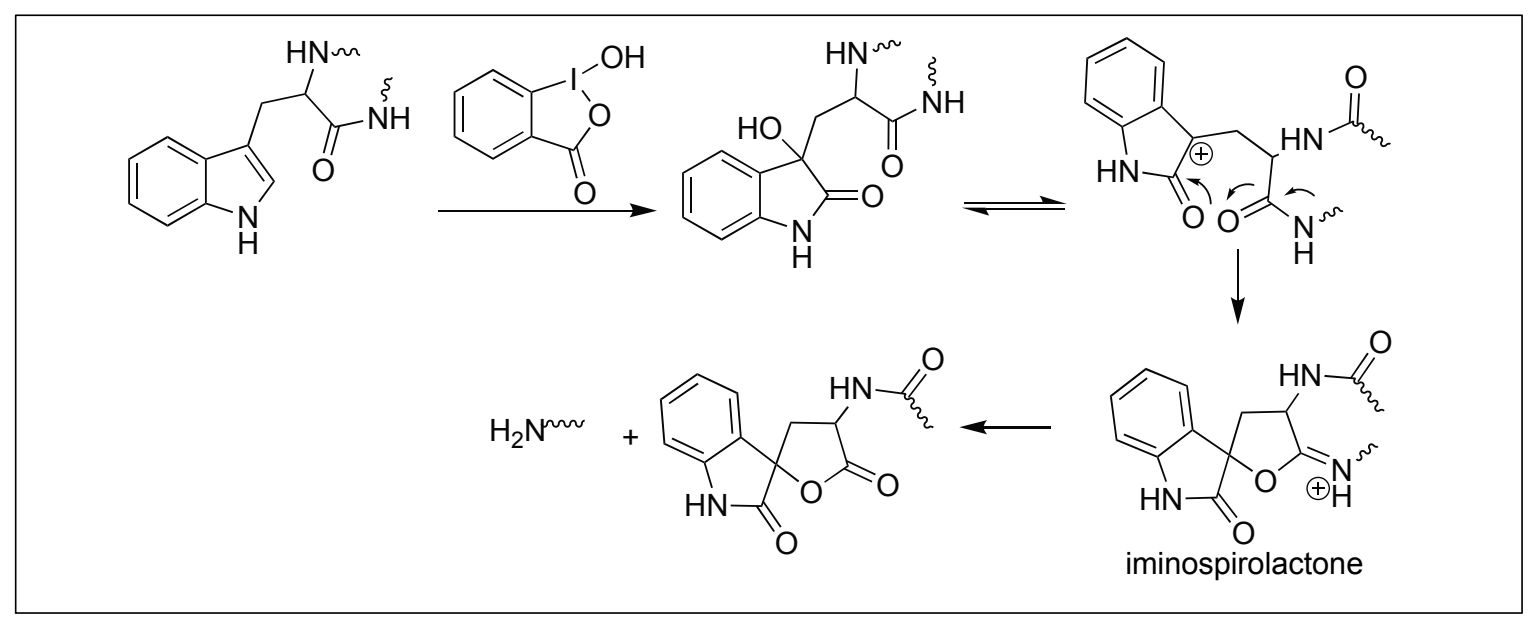

Figure 39. Iodosobenzoic acid for hydrolysis.

\subsubsection{TBC for Cleavage at Trp}

Tryptophanyl peptide bonds underwent selective cleavage by 2,4,6-tribromo-4methylcyclohexadienone (TBC) at the C-terminus (Figure 40). Tyrosyl and histidyl peptide bonds which are usually cleaved by other brominating agents (such as $\alpha$-bromosuccinimide, $\alpha$-bromoacetamide, etc.) are stable to this reagent. Additionally, other amino acids, which are sensitive to oxidation, react with TBC but do not cleave the peptide bonds. This method was successfully applied to a variety of peptides and proteins $[118,119]$.

According to the reaction mechanism suggested by Patchornik et al. (1960), oxidative bromine participates in the modification-cleavage reaction $[118,119]$. Two equivalents of bromine first brominate the indole nucleus followed by a spontaneous debromination through a series of oxidation and hydrolysis reactions (Figure 40). These reactions led to the formation of an oxindole derivative, which cleaves the peptide bond. 


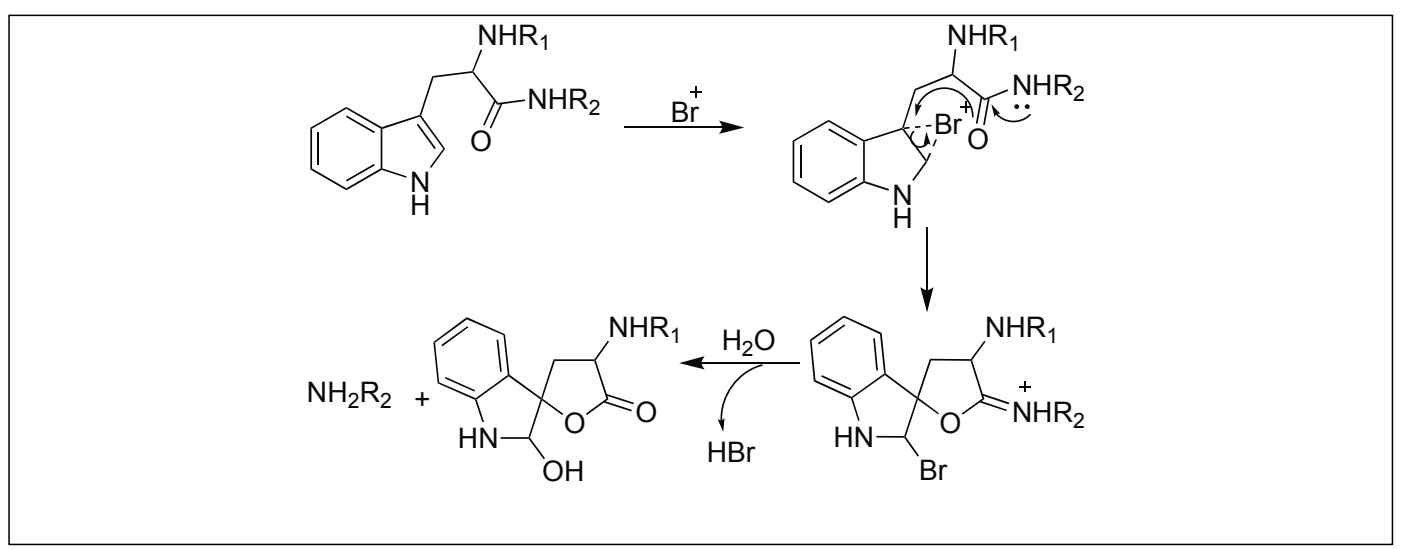

Figure 40. TBC for selective cleavage at Trp residue.

\subsection{N-Amidination for Cleavage of the N-Terminal Amide Bond}

Hamada et al. reported the cleavage of the amide bonds by the $N$-amidination of peptides. The $N$-amidination of peptides leads to the formation of a cyclic moiety which resulted in the cleavage of the amide bond at room temperature (Figure 41) [120]. The rate of cleavage was slow under ambient conditions (PBS buffer, $\mathrm{pH} 7.4$ ) at $37^{\circ} \mathrm{C}$ with $\mathrm{t}_{1 / 2}=35.7 \mathrm{~h}$, but a rapid cleavage was observed under basic conditions ( $2 \% \mathrm{NaOH}$ aq) with $\mathrm{t}_{1 / 2}=1.5 \mathrm{~min}$. To evaluate the broad applicability of this cleavage reaction, a series of peptides with different amino acids at the N-terminus such as the Lys, Glu, Ser, Cys, Tyr, Val, and Pro residues were cleaved with $t_{1 / 2}$ values from $1 \mathrm{~min}$ to $10 \mathrm{~min}$. A slightly slow cleavage was observed with bulky amino acids at the terminus such as Val or Pro, which might be hindering the path of cyclization.

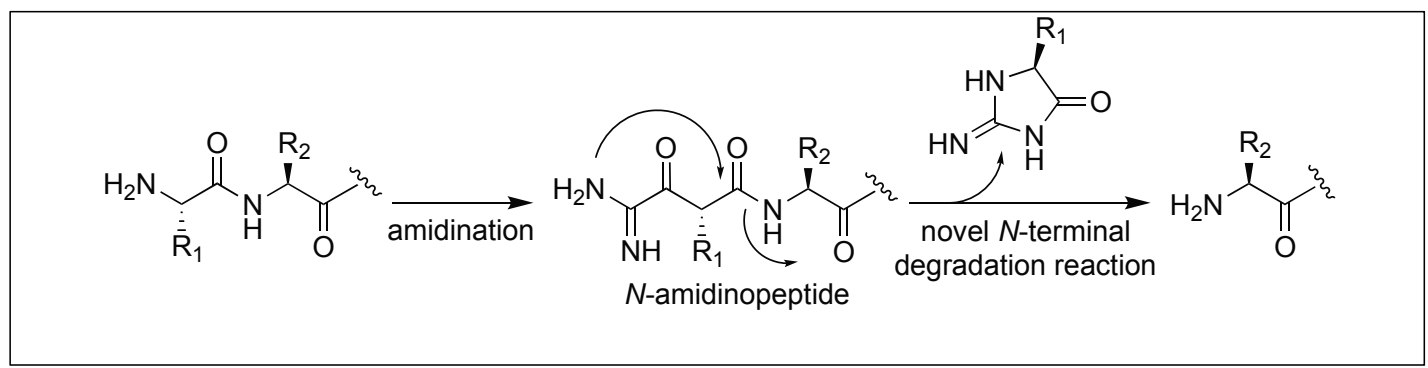

Figure 41. N-amidination strategy.

$\mathrm{N}$-amidinated peptide with a Cys residue at the N-terminus also generated a five-membered ring, thiazolidine by path $b$ (intermediate B) which did not lead to any cleavage, therefore, the $t_{1 / 2}$ of the peptide with $\mathrm{Cys}$ at the $\mathrm{N}$-terminus in $2 \% \mathrm{NaOH}$ aq at $37{ }^{\circ} \mathrm{C}$ was $3.4 \mathrm{~min}$ (slower than with other amino acids at the N-terminus) (Figure 42) [120].

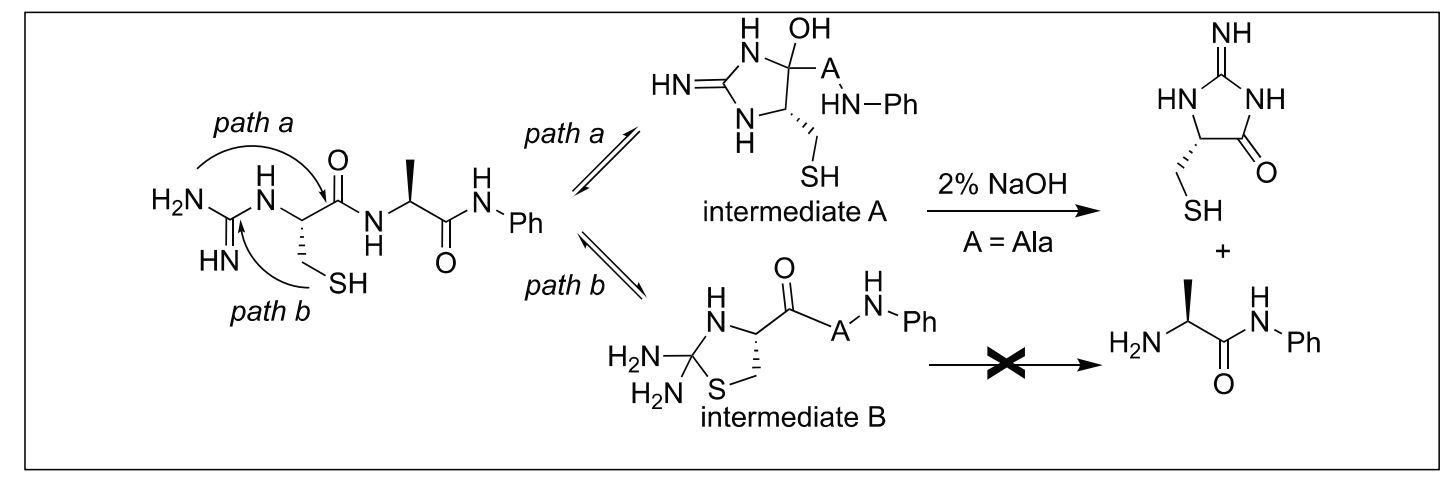

Figure 42. N-amidination strategy with N-terminal cysteine. 


\subsection{Lactonization Mediated Cleavage of Amide Bonds}

Otaka et al. developed an auxiliary with special protecting groups (PGs), which is capable of forming a lactone with the carbonyl of an amide bond, resulting in the cleavage of the amide bond (Table 4) [121-128]. Depending on the nature of the protecting groups, an amide bond cleavage can be initiated in peptides by using different responsive reagents for the deprotection of PGs (Table 4). Table 4 showed various PGs and the corresponding responsive reagents for their deprotection. The thiol responsive reagent was applied for the cleavage of the PNA/DNA complex using thiol-responsive protecting groups [121-128].

Table 4. Lactonization mediated cleavage of amide bonds.

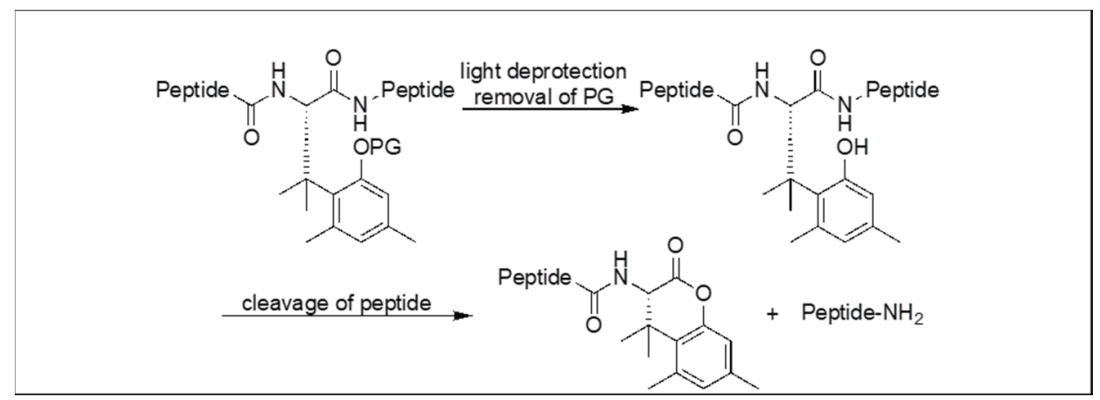

\begin{tabular}{|c|c|c|c|c|}
\hline Reagent/Condition & PG & R1 & $\mathbf{R} 2$ & $\mathbf{R} 3$ \\
\hline \multirow{4}{*}{$\begin{array}{l}\text { Ultraviolet Near-infrared } \\
\text { Fluoride hypoxia }\end{array}$} & & $\mathrm{NO}_{2}$ & $\mathrm{H}$ & $\mathrm{H}$ \\
\hline & & $\mathrm{NO}_{2}$ & $\mathrm{OMe}$ & $\mathrm{OMe}$ \\
\hline & & $\mathrm{H}$ & OTBDPS & $\mathrm{H}$ \\
\hline & $\mathrm{R}_{2}$ & $\mathrm{H}$ & $\mathrm{NO}_{2}$ & $\mathrm{H}$ \\
\hline Thiol & 4-nitrobenzenesulfonyl & - & - & - \\
\hline Phosohatase & phosphate & - & - & - \\
\hline
\end{tabular}

\subsection{Hydrogen Peroxide-Induced Amide Bond Cleavage}

Later, the hydrogen peroxide $\left(\mathrm{H}_{2} \mathrm{O}_{2}\right)$-responsive protecting group was introduced to the amino acid. This protecting group contains a boronate or boronic acid moiety which underwent deprotection in oxidative stress because of the release of hydrogen peroxide followed by the formation of lactone and the cleavage of the peptide bond (Figure 43) [128].

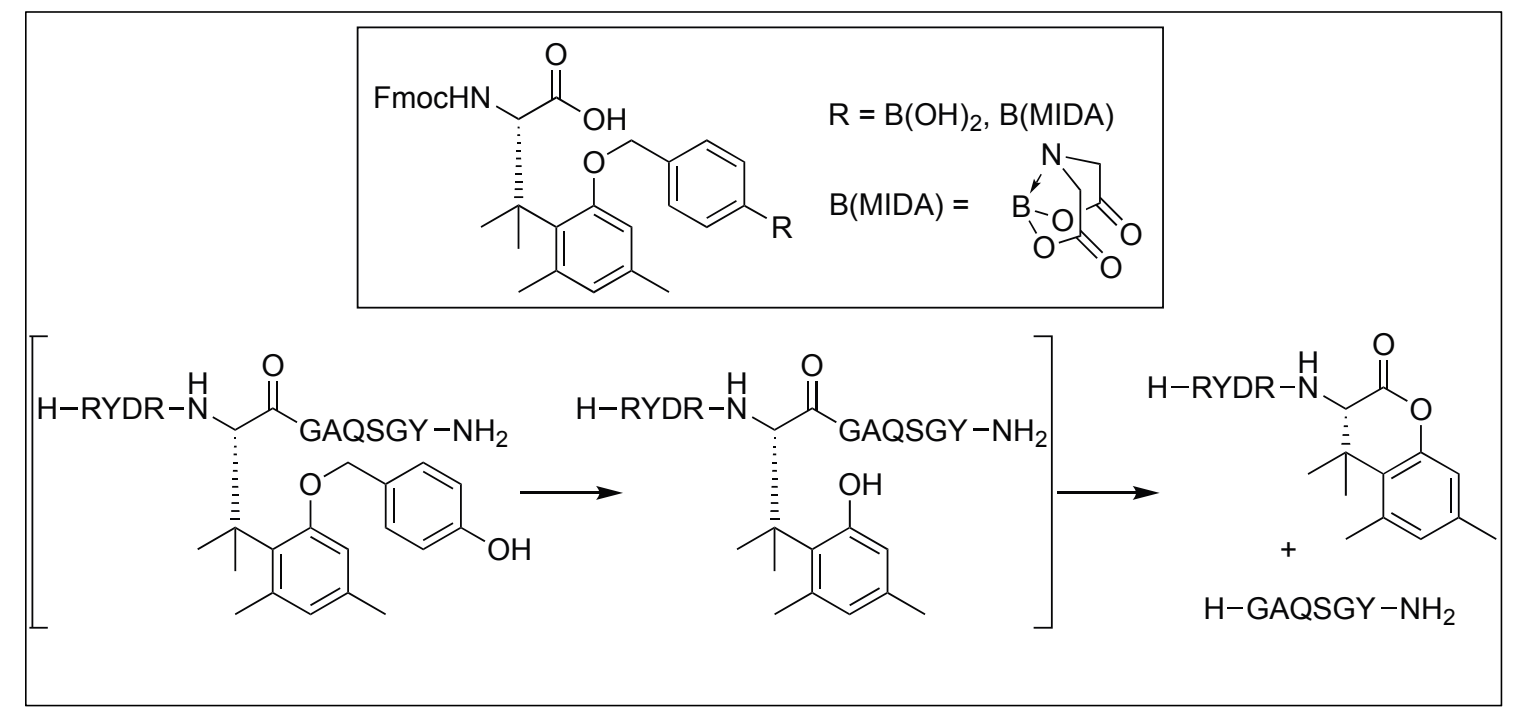

Figure 43. Hydrogen peroxide responsive probes. 


\subsection{Glutamic Acid Specific Activation of Amide Bonds}

We have also reported a new method for the site-specific cleavage of peptide bonds at glutamic acid under physiological conditions $[129,130]$. The method involves the activation of the backbone peptide chain at the N-terminal side of glutamic acid by the formation of a pyroglutamyl imide (pGlu) moiety using bromotripyrrolidinophosphonium hexafluorophosphate (PyBroP) (Figure 44). This activation increases the susceptibility of the peptide bond toward various nucleophiles including thiol and water (Figure 44). We showed that this pyroglutamyl imide activated peptide chain underwent the complete cleavage of the peptide bond under neutral buffer conditions ( $\mathrm{pH} 7.5$ ). It was observed that the rate of hydrolysis increase under basic $\mathrm{pH}$ conditions $(\mathrm{pH}=10.5)$. Although the Asp has a carboxylic group on the side chain, no cleavage was observed under the reaction conditions. Jensen et al. exposed the pGlu activated peptide bond towards thiol, resulting in the formation of peptide thioesters $[129,130]$. A noted feature about this approach is that it leads to the formation of epimerization free peptide acids and peptide thioesters. This method is highly specific and exhibits a broad substrate scope including the cleavage of bioactive peptides with unnatural amino acids, which are unsuitable substrates for enzymes.

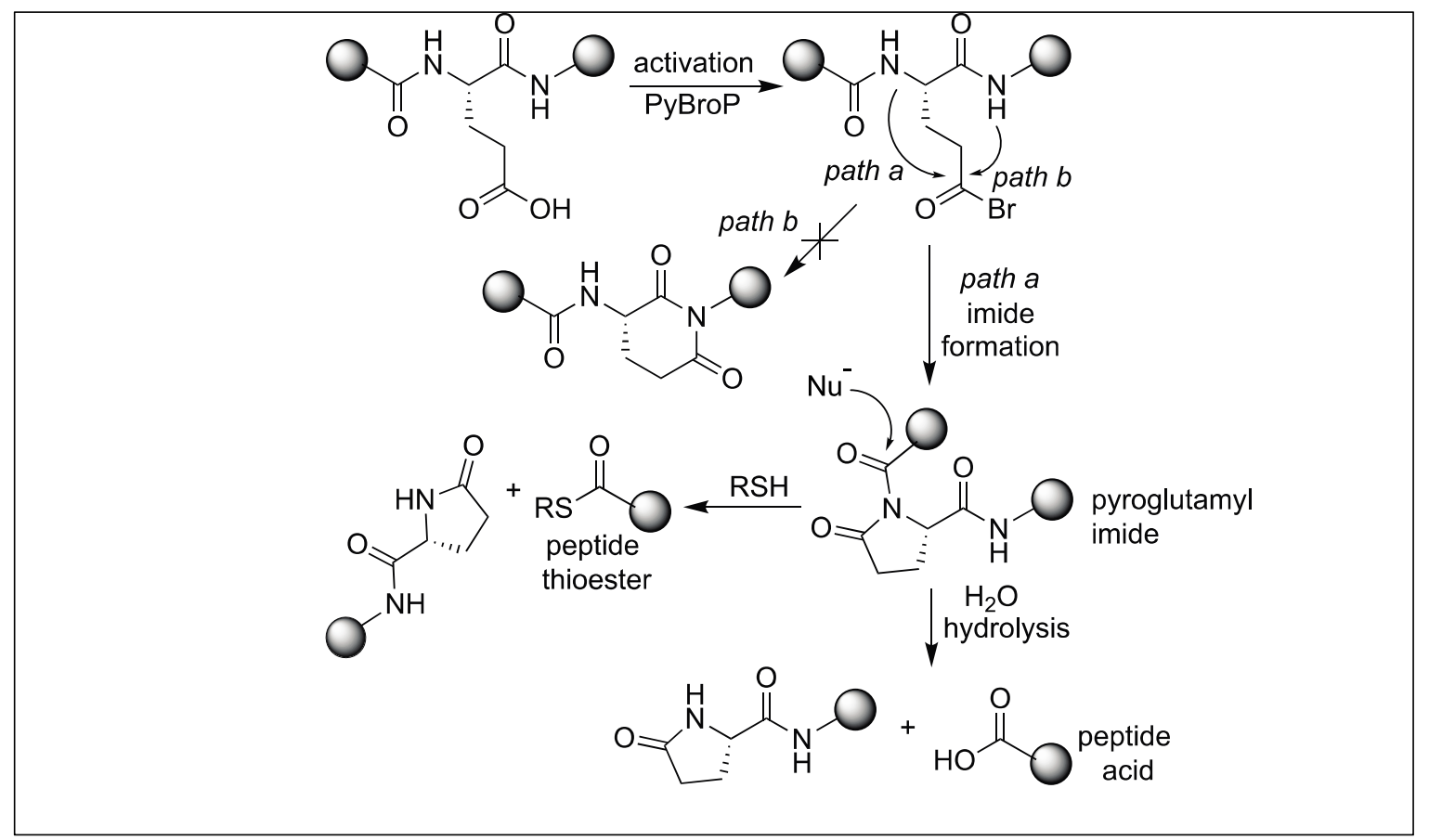

Figure 44. Glutamic acid selective activation of peptide bonds.

\subsection{Asparagine Selective Cleavage of Amide Bonds}

Kanai et al. described the method for the site-selective chemical activation of peptide bonds for hydrolysis at the asparagine residue using diacetoxyiodobenzene (DIB) [131]. The reaction of the side-chain of Asn with DIB leads to the formation of isocyanate by Hofmann rearrangement. This is followed by the attack of the $\mathrm{N}$-terminal amidic nitrogen of the peptide backbone chain, affording a five-membered $\mathrm{N}$-acylurea intermediate, thus activating the amide bond towards hydrolysis (Figure 45). Asn-selective peptide bond cleavage was proceeded in an aqueous neutral solution at $37^{\circ} \mathrm{C}$ and exhibited a broad substrate scope. The Gln-site was not cleaved under the reaction conditions. Specifically, this method is applicable to peptides containing unnatural amino acids and/or posttranslational modifications where enzymatic cleavage is not very efficient. 




Figure 45. Asparagine selective cleavage of peptide bonds.

\subsection{Cyclic Urethane Mediated Activation of Amide Bonds}

We have developed a method for the cleavage of the amide backbone chain at the $\mathrm{N}$-terminal side of Ser, Thr, and Cys by the formation of a five-membered cyclic urethane moiety [132]. The formation of the cyclic urethane moiety with an amide backbone makes the amidic carbonyl group susceptible to nucleophilic attack. This is presumably due to the twist in the backbone amide chain caused by the cyclic urethane moiety. Thus, it was no longer able to form a resonating structure. To achieve this goal, we screened various carbonylating reagents and a maximum conversion to cyclic urethane moiety was achieved with $N, N$-disuccinimidyl carbonate (DSC). We proposed that the hydroxymethyl group of the side chain of Ser reacted with DSC to generate an activated intermediate, A, which then undergoes nucleophilic displacement by the amidic nitrogen on the $\mathrm{N}$-side of serine through the path to generate a five-membered cyclic urethane intermediate B (Figure 46). The formation of the cyclic urethane intermediate $\mathrm{B}$ makes the amide bond susceptible to nucleophilic attack and led to the cleavage of the amide bond in neutral aqueous conditions (room temp, $\mathrm{pH} 7.5,12 \mathrm{~h}$ ). There is a possibility of nucleophilic displacement of the intermediate $A$ by the amidic nitrogen through path $b$. This could lead to the formation of six-membered ring $\mathrm{B}^{\prime}$, but we did not observe the formation of any six-membered ring as analyzed by NMR studies.

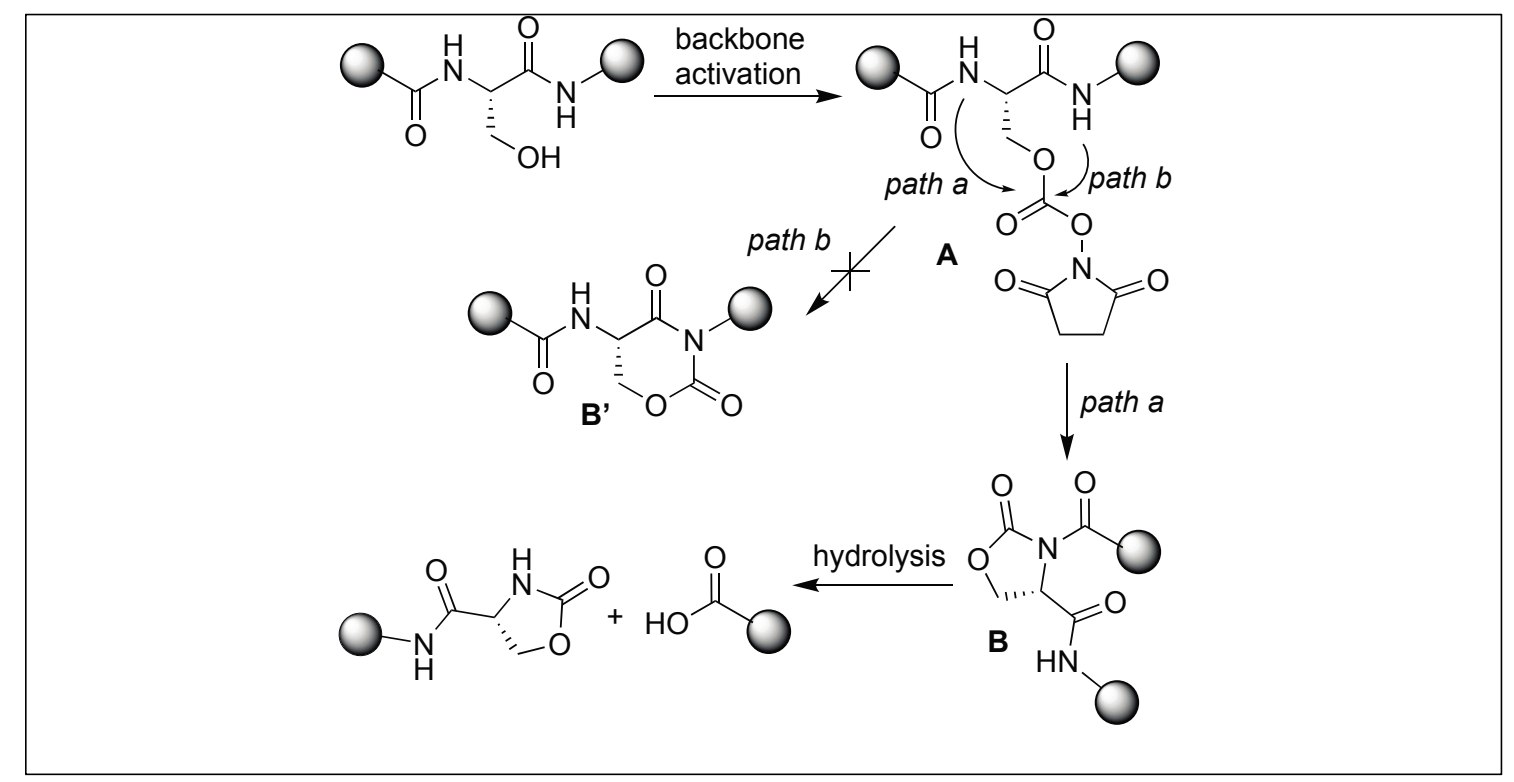

Figure 46. Cyclic urethane mediated activation of peptide bond. 
The side chain of Glu on reaction with DSC also led to the formation of a pyroglutamyl imide moiety with an amide backbone chain, thus making it susceptible to nucleophilic attack (Figure 47) [132]. We have used this approach for the selective hydrolysis of peptides/proteins at the N-terminus of Ser, Thr, Cys, and Glu. This method cleaved various bioactive peptides containing posttranslational modifications (e.g., $\mathrm{N}$-acetylation and -methylation) and mutations (D-and $\beta$-amino acids), which are not suitable substrates for enzymes, thus exhibited a broad substrate scope. We have also used this approach for the synthesis of a variety of functionalized C-terminal peptides such as esters, amides, alcohols, and thioesters (Figure 48) by exposing the cyclic urethane activated peptide towards various nucleophiles such as alcohols, amines, reducing agents, and thiols $[133,134]$. The attractive feature of this approach is that it leads to the formation of epimerization free C-functionalized peptides.



Figure 47. Pyroglutamyl imide mediated activation of peptide bond.

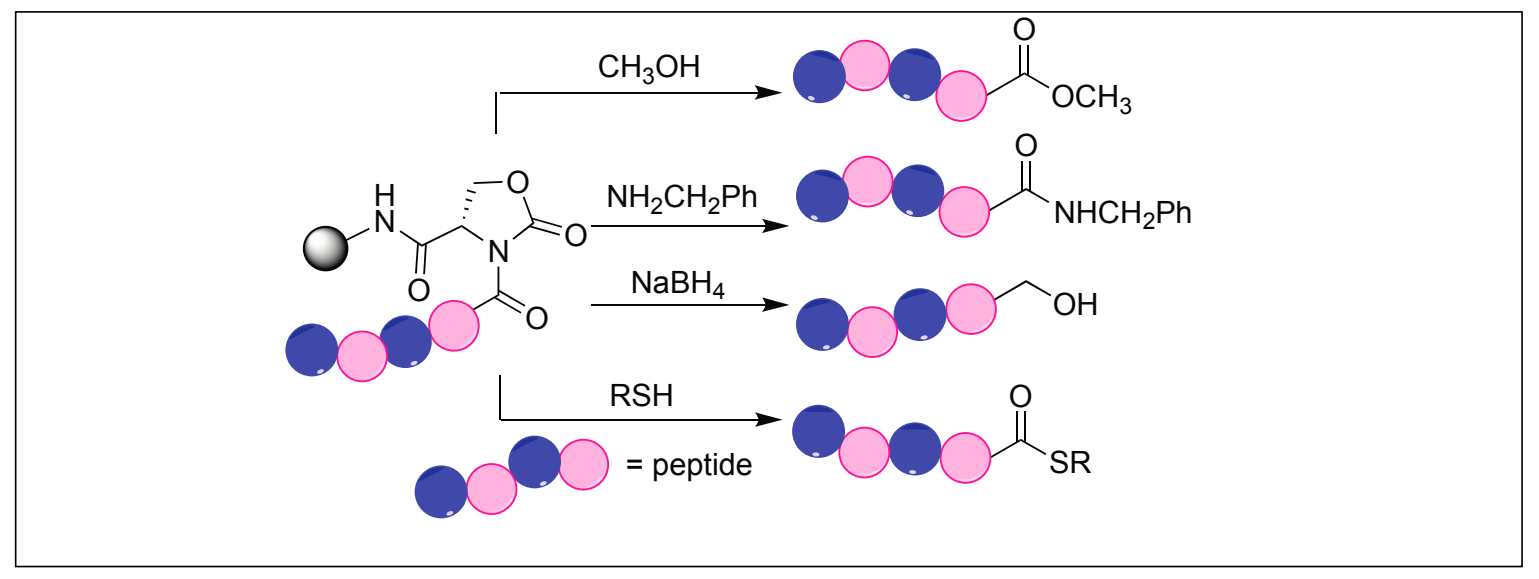

Figure 48. Cyclic urethane mediated synthesis of C-terminal peptides.

Later, this cyclic urethane amide-activation approach was applied for the cleavage of a variety of cyclic and lasso peptides obtained from nature to determine their sequence, which is difficult to be determined by conventional approaches (Figure 49) [135,136]. We have also applied this method for the synthesis of a peptide-based molecular machine (rotaxanes) for the first time (Figure 50) $[135,136]$. 


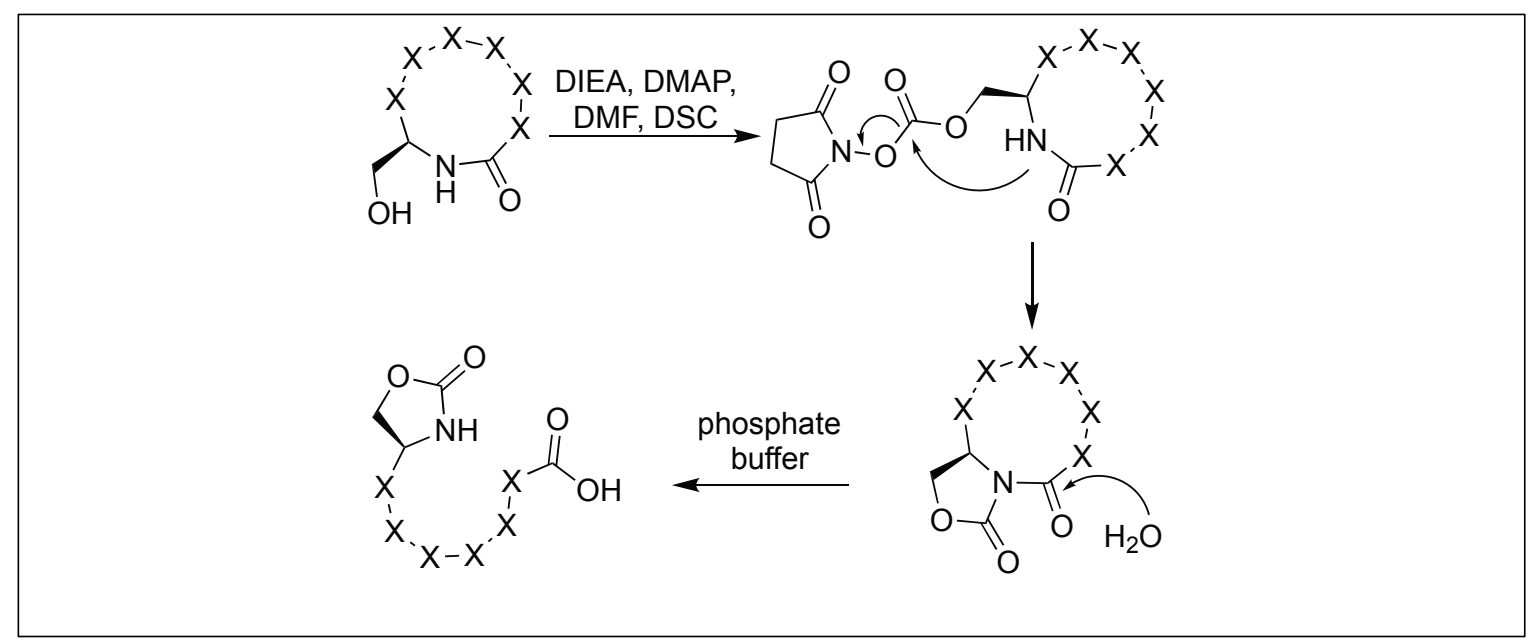

Figure 49. Cyclic urethane for cleavage of cyclic peptides.

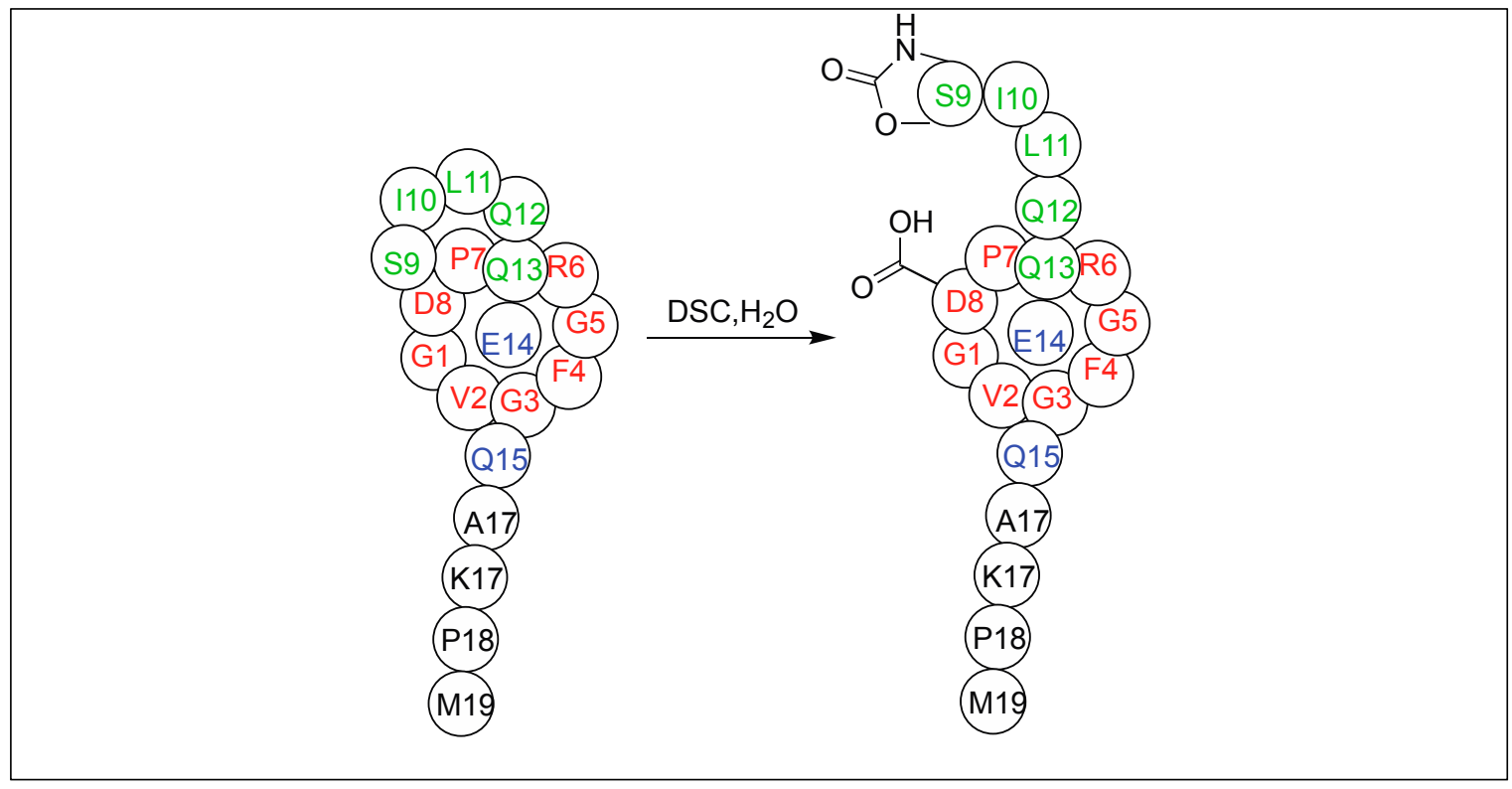

Figure 50. Synthesis of rotaxane from lasso peptide.

\subsection{Intein-Inspired Amide Cleavage Chemical Device}

A photoresponsive device was developed for the cleavage of the amide bond at the C-terminus of the Asn residue [137]. This approach was inspired by intein-mediated protein splicing and its chemical environment was mimicked by the incorporation of geminal dimethyl groups and a secondary amine on the asparagine scaffold.

The secondary amine acts as an intramolecular base, which enhances the nucleophilicity of the amide nitrogen (Figure 51). The geminal dimethyl groups led to a Thorpe-Ingold effect, which enhances the intramolecular attack, thus assisting in the formation of the succinimide ring [138-140]. The o-nitrobenzyloxycarbonyl (o-NBnoc) masks the basic character of the secondary amine [141,142], thus leading to the photo triggered cleavage of an amide bond by the deprotection of the secondary amine unit containing the $o$-nitrobenzyloxycarbonyl group. 


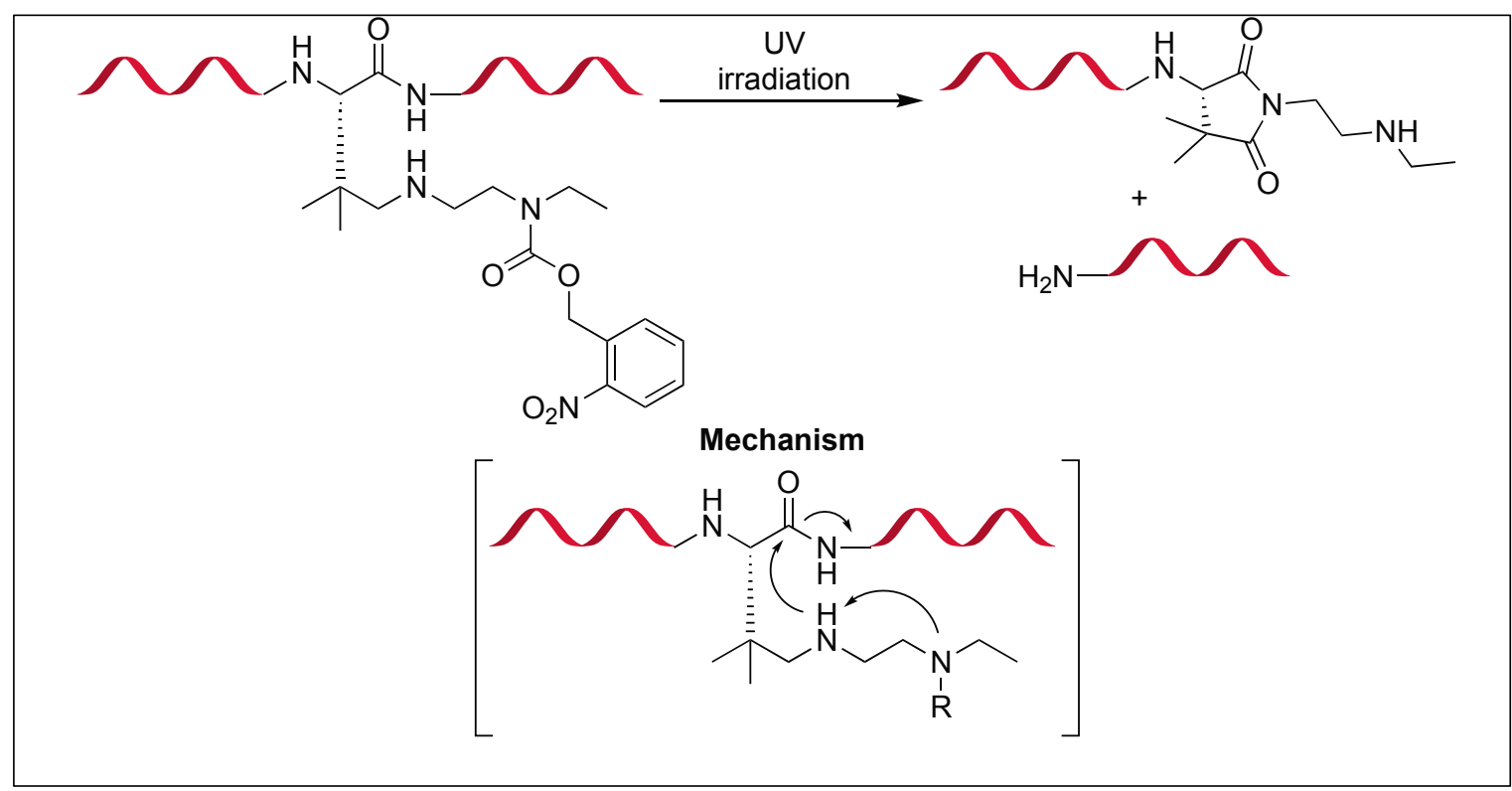

Figure 51. Intein-inspired amide bond cleavage.

\subsection{Serine-Selective Aerobic Cleavage of Peptides}

Kanai et al. reported a use of the water-soluble copper-organoradical conjugate for the selective cleavage of the peptide bond at the $\mathrm{N}$-terminus of a serine residue under mild conditions and at room temperature [143]. They used this approach for the selective cleavage of a variety of different peptides/proteins containing D-amino acids or sensitive disulfide pairs.

Ser-selective cleavage of the peptide bond was initiated by the aerobic chemoselective oxidation of the hydroxymethyl moiety of Ser to a formyl group (A) (Figure 52). This produced a $\beta$-formyl glycineamide intermediate $\mathbf{B}$ which, on further oxidation, led to the formation of oxalamide $\mathbf{C}$ by undergoing oxidative deformylation. Oxalamide $\mathbf{C}$ then underwent hydrolysis under mild conditions because the carbonyl groups of the oxalamide are more electrophilic than those of simple amides, resulting in the formation of the cleaved fragments $\mathbf{D}$ and $\mathbf{D}^{\prime}$. By using molecular oxygen as a terminal oxidant, water and a $\mathrm{C} 1$ molecule (possibly $\mathrm{HCO}_{2} \mathrm{H}$ ) become stoichiometric side products. This strategy is widely distinct from Lewis acid, promoted by the Ser-selective peptide hydrolysis through N-to-O rearrangement.

\subsection{Hydrolysis of Amide Bonds by the Formation of Oxazolinium Specie: Function of Acyl Protecting Group}

Peptides containing a simple $N$-acyl group activates the amide bond four bonds away from an acyl group for cleavage under acidic conditions [144]. First, TFA leads to the protonation of amide carbonyl followed by the nucleophilic attack from the oxygen of the acyl carbonyl to generate a five-membered oxazolinium specie $\mathbf{A}$ in the peptide chain. Second, the collapse of the oxazolinium intermediate $\mathbf{A}$ leads to the cleavage of an unactivated amide bond (Figure 53).

The nature of the aromatic group, G, was responsible for the rate of hydrolysis of the peptide bond. Electron-donating groups increase the rate of hydrolysis whereas electron withdrawing substituents decrease it (Figure 53). 


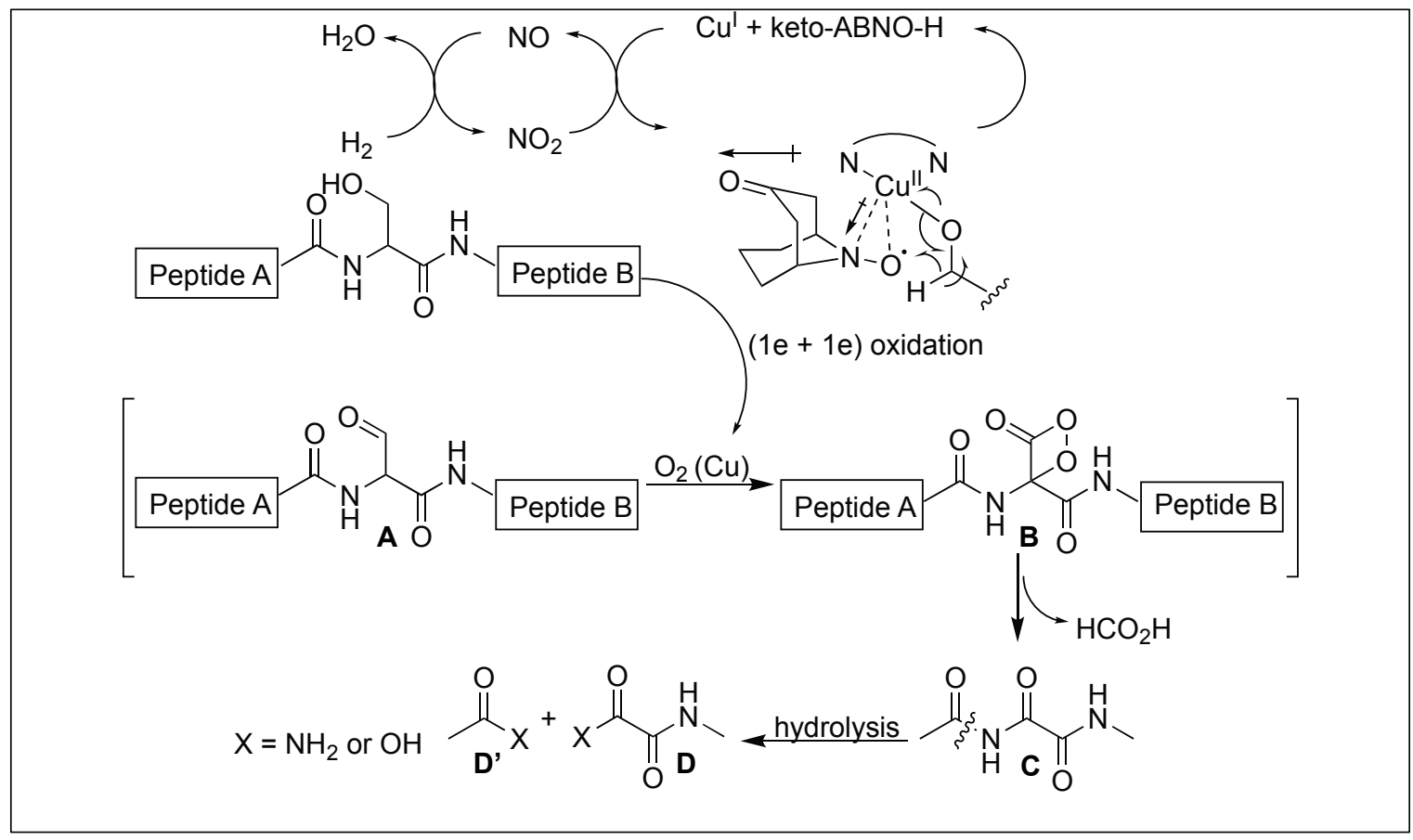

Figure 52. Serine selective aerobic cleavage of peptide bonds.

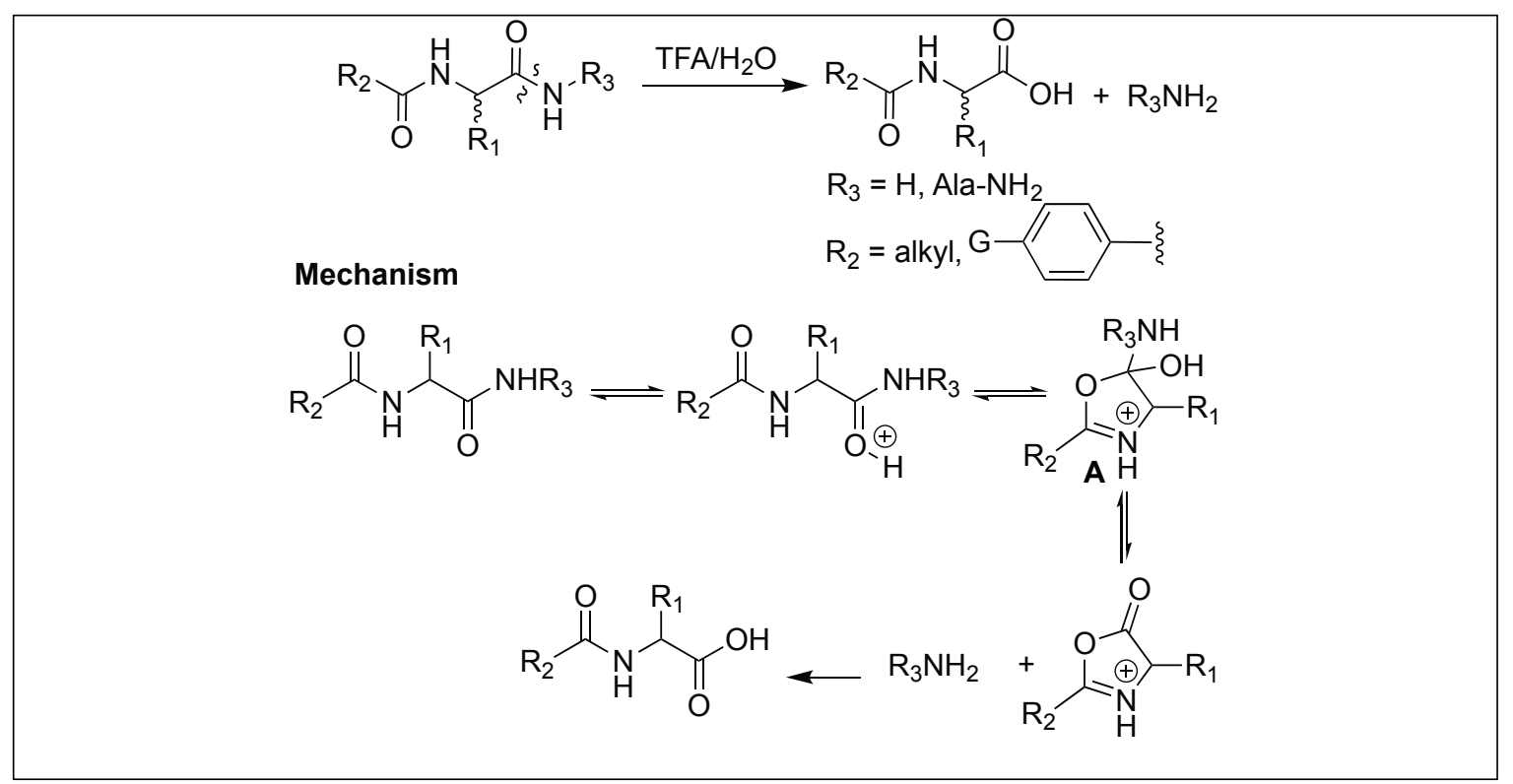

Figure 53. Oxazolinium species formation.

\subsection{Hydrazinolysis for the Cleavage of Amide Bonds}

The hydrazinolysis of unactivated amide bonds was accelerated by the addition of ammonium salts. The reaction proceeds at $50-70{ }^{\circ} \mathrm{C}$ to give peptide cleavage products and exhibits a broad substrate scope that out-performs existing amide bond cleavage reactions [145]. This approach was applied for the cleavage of the peptide bonds without racemization at the $\alpha$-position of the amino acids (Figure 54). It was also applied to the cleavage of the $N$-acetyl group from the amino sugar. 


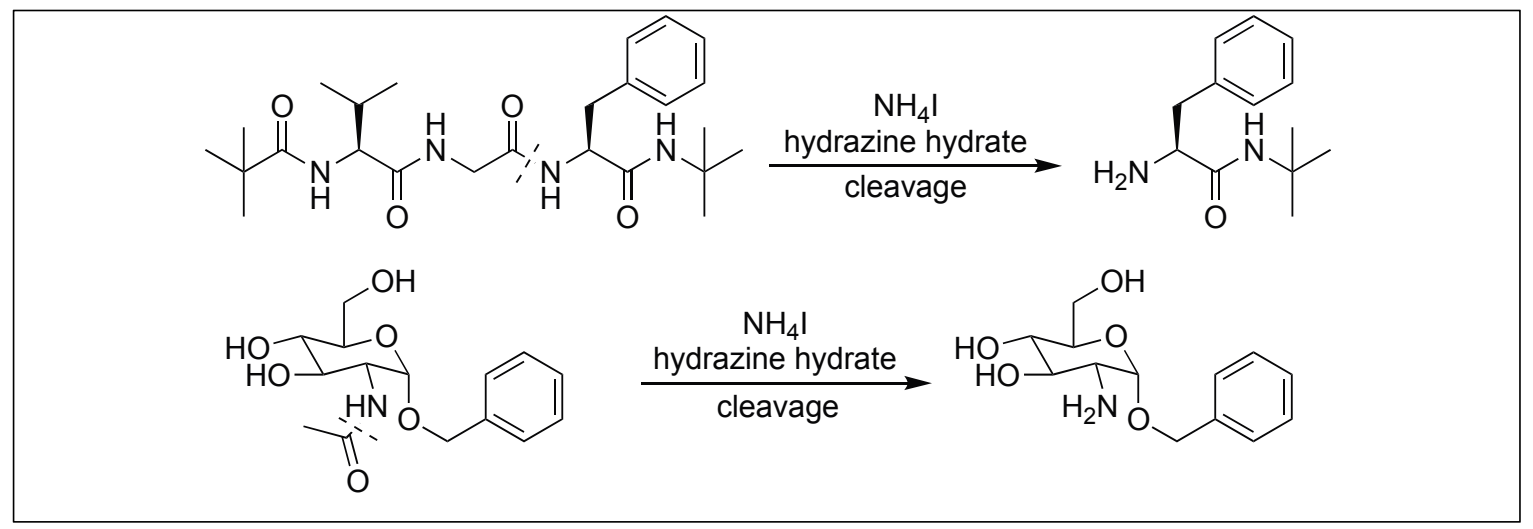

Figure 54. Hydrazinolysis for the cleavage of peptide bonds.

\subsection{Amide Bond Cleavage of the N-Methylcysteinyl Peptide}

Tam et al. developed a selective bi-directional peptide bond cleavage approach utilizing $\mathrm{N}$-methylcysteine (MeCys) in the Xaa-MeCys-Yaa peptides (Xaa and Yaa, non-cysteine residues) [146]. Under strong acidic conditions, peptide Xaa-MeCys-Yaa led to the formation of an oxazolinium intermediate, resulting in the cleavage of the Xaa-MeCys bond. The oxazolinium intermediate was later trapped by thiocresol (TC) to form a Xaa-MeCys-TC thioester (Figure 55). The replacement of MeCys by Cys residue did not result in the peptide bond cleavage, suggesting the important role of $\mathrm{N}$-methylation in MeCys residue for the formation of oxazolone.

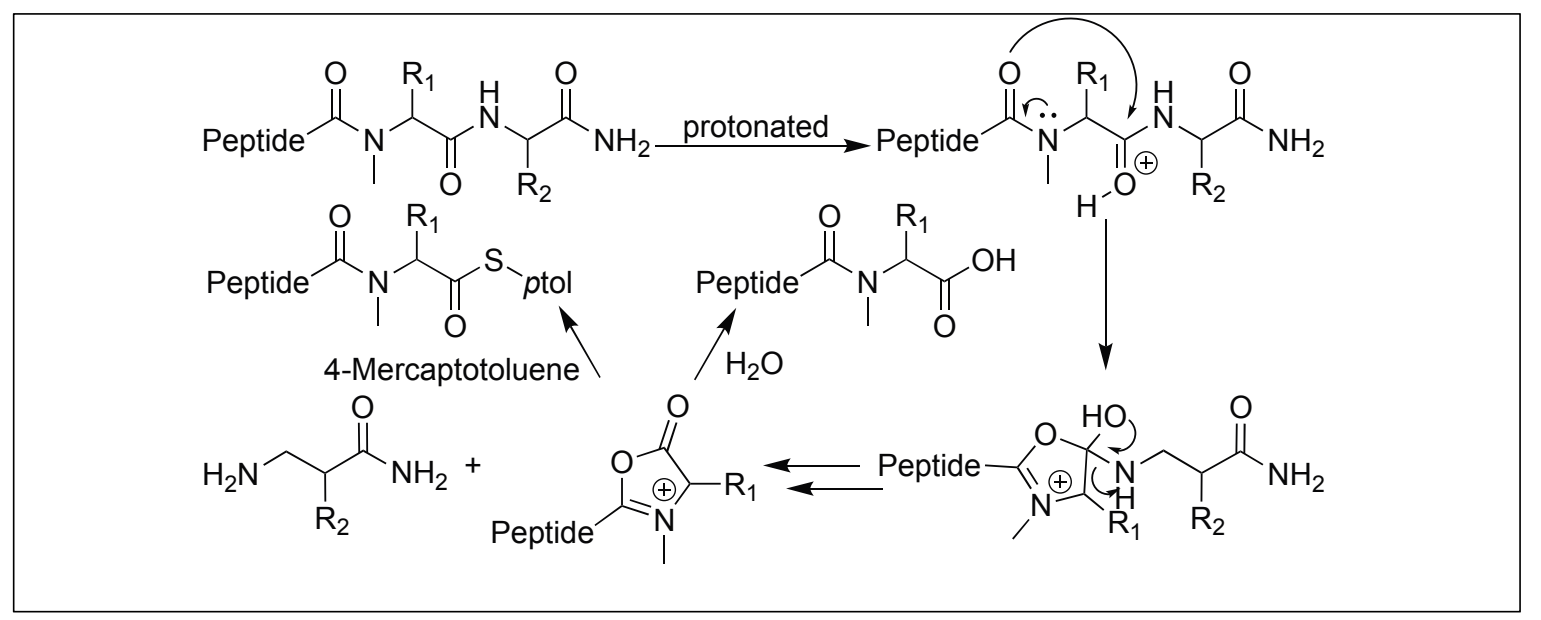

Figure 55. $N$-methylcysteinyl peptide cleavage.

\subsection{N-MeAib Induced Unusual Cleavage of Amide Bonds}

Peptides containing acylated $N$-methyl-aminoisobutyryl (NMeAib) residues showed unusual cleavage of amide bonds under acidic conditions. The cleavage takes place at the C-terminal side of the NMeAib residue (Figure 56) [147]. X-ray diffraction studies of the NMeAib containing molecules showed that the oxygen atom of the carbonyl group of the preceding residue is close to the carbonyl carbon of the NMeAib residue, thus acting as an internal nucleophile forming a tetrahedral intermediate. Once this tetrahedral intermediate was formed, lone pair electrons on the nitrogen of the phenylalanine were no longer be able to form resonating structures with the carbonyl group of NMeAib. In fact, the phenylalanine nitrogen becomes a proton acceptor like the amines, which resulted in the cleavage of the amide bond followed by the removal of phenylalanine and the formation of an oxazolinium ion intermediate, which further reacts with water to form a carboxylic acid product. 




Figure 56. N-Me Aib mediated amide bond cleavage.

\section{Conclusions}

This mini-review highlights the methods for the activation of unactivated amide bonds in biomolecules. This review further highlights the application of these methods in the sequencing of proteins and the synthesis of peptide acids, thioesters, alcohols, and amides. These studies showed that there is still a lot to learn from enzymes catalyzed pathways and how we can develop enzyme mimetics for catalyzing the cleavage of unactivated and highly stable amide bonds at particular residues in a selective manner. We assume that these enzyme mimetics can have potential applications in various fields.

Author Contributions: M.R., S.M. and K.-C.T. collected the literature references. M.R., S.M. and K.-C.T. contributed to the manuscript writing.

Funding: This research was supported by start up funds granted to M.R. by Auburn University.

Conflicts of Interest: The authors declare no conflicts of interest.

\section{References}

1. Greenberg, A.; Breneman, C.M.; Liebman, J.F. The Amide Linkage: Structural Significance, Shemistry, Biochemistry and Material Science; Wiley: New York, NY, USA, 2000.

2. Brunton, L.; Chabner, B.; Knollman, B. Goodman and Gilman's the Pharmacological Basis of Therapeutics; MacGraw-Hill: New York, NY, USA, 2010.

3. Brown, D.G.; Bostrom, J. Analysis of Past and Present Synthetic Methodologies on Medicinal Chemistry: Where Have All the New Reactions Gone? J. Med. Chem. 2016, 59, 4443-4458. [CrossRef] [PubMed]

4. Pattabiraman, V.R.; Bode, J.W. Rethinking amide bond synthesis. Nature 2011, 480, 471-479. [CrossRef] [PubMed]

5. Hughes, A.B. Amino Acids, Peptides and Proteins in Organic Chemistry; Wiley-VCH: Weinheim, Germany, 2009.

6. Kaspar, A.A.; Reichert, J.M. Drug future directions for peptide therapeutics development. Discov. Today 2013, 18, 807-817. [CrossRef] [PubMed]

7. Thorner, J.; Emr, S.D.; Abelson, J.N. Applications of chimeric genes and hybrid proteins part A: Gene expression and protein purification. Methods Enzymol. 2000, 326, 601-617.

8. Kemnitz, C.R.; Loewen, M.J. Amide Resonance correlates with a breadth of C-N rotation barriers. J. Am. Chem. Soc. 2007, 129, 2521-2528. [CrossRef] [PubMed]

9. Mujika, J.I.; Mercero, J.M.; Lopez, X. Water-promoted hydrolysis of a highly twisted amide: Rate acceleration caused by the twist of the amide bond. J. Am. Chem. Soc. 2005, 127, 4445-4453. [CrossRef] [PubMed]

10. Wang, B.; Cao, Z. Acid-catalyzed reactions of twisted amides in water solution: Competition between hydration and hydrolysis. Chem.-Eur. J. 2011, 17, 11919-11929. [CrossRef] [PubMed] 
11. Smith, R.M.; Hansen, D.E. The pH-rate profile for the hydrolysis of a peptide bond. J. Am. Chem. Soc. 1998, 120, 8910-8913. [CrossRef]

12. Radzicka, A.; Wolfenden, R. Rates of uncatalyzed peptide bond hydrolysis in neutral solution and the transition state affinities of proteases. J. Am. Chem. Soc. 1996, 118, 6105-6109. [CrossRef]

13. Arnau, J.; Lauritzen, C.; Petersen, G.E.; Pedersen, J. Current strategies for the use of affinity tags and tag removal for the purification of recombinant proteins. Protein Express. Purif. 2006, 48, 1-13. [CrossRef] [PubMed]

14. Hoyer, D.; Cho, H.; Schultz, P.G. New strategy for selective protein cleavage. J. Am. Chem. Soc. 1990, 112, 3249-3250. [CrossRef]

15. Schepartz, A.; Cuenoud, B. Site-specific cleavage of the protein calmodulin using a trifluoperazine-based affinity reagent. J. Am. Chem. Soc. 1990, 112, 3247-3249. [CrossRef]

16. Tani, K.; Stoltz, B.M. Synthesis and structural analysis of 2-quinuclidonium tetrafluoroborate. Nature 2006, 441, 731. [CrossRef] [PubMed]

17. Hayashi, M.; Bachman, S.; Hashimoto, S.; Eichman, C.C.; Stoltz, B.M. Catalytic anti-Markovnikov transformations of hindered terminal alkenes enabled by aldehyde-selective Wacker-type oxidation. J. Am. Chem. Soc. 2016, 138, 8997-9000. [CrossRef] [PubMed]

18. Kirby, A.J.; Komarov, I.V.; Wothers, P.D.; Feeder, N. The most twisted amide: Structure and reactions. Angew. Chem. Int. Ed. 1998, 37, 785-786. [CrossRef]

19. Kirby, A.J.; Komarov, I.V.; Feeder, N. Spontaneous, millisecond formation of a twisted amide from the amino acid, and the crystal structure of a tetrahedral intermediate. J. Am. Chem. Soc. 1998, 120, 7101-7102. [CrossRef]

20. Kirby, A.J.; Komarov, I.V.; Feeder, N. Synthesis, structure and reactions of the most twisted amide. J. Chem. Soc. Perkin Trans. 2001, 2, 522-529. [CrossRef]

21. Szostak, M.; Aube, J. Chemistry of bridged lactams and related heterocycles. Chem. Rev. 2013, $113,5701$. [CrossRef] [PubMed]

22. Artacho, J.; Ascic, E.; Rantanen, T.; Karlsson, J.; Wallentin, C.J.; Wang, R.; Wendt, O.F.; Harmata, M.; Snieckus, V.; Warnmark, K. Twisted amide analogues of Troger's base. Chem. Eur. J. 2012, 18, 1038-1042. [CrossRef] [PubMed]

23. Bashore, C.G.; Samardjiev, I.J.; Bordner, J.; Coe, J.W. Twisted amide reduction under Wolff-Kishner conditions: Synthesis of a benzo-1-aza-adamantane derivative. J. Am. Chem. Soc. 2003, 125, 3268. [CrossRef] [PubMed]

24. Meng, G.; Szostak, M. Sterically controlled Pd-catalyzed chemoselective ketone synthesis via N-C cleavage in twisted amides. Org. Lett. 2015, 17, 4364-4367. [CrossRef] [PubMed]

25. Meng, G.; Szostak, M. General olefin synthesis by the palladium catalyzed Heck reaction of amides: Sterically controlled chemoselective N-C activation. Angew. Chem. Int. Ed. 2015, 54, 14518-14522. [CrossRef] [PubMed]

26. Shi, S.; Meng, G.; Szostak, M. Synthesis of biaryls through nickel catalyzed Suzuki-Miyaura coupling of amides by carbon-nitrogen bond cleavage. Angew. Chem. Int. Ed. 2016, 55, 6959-6963. [CrossRef] [PubMed]

27. Shi, S.; Szostak, M. Efficient synthesis of diaryl ketones by nickel-catalyzed Negishi cross-coupling of amides by carbon-nitrogen bond cleavage at room temperature accelerated by a solvent effect. Chem.-Eur. J. 2016, 22, 10420-10424. [CrossRef] [PubMed]

28. Meng, G.; Szostak, M. Rhodium-catalyzed C-H bond functionalization with amides by double C-H/C-N bond activation. Org. Lett. 2016, 18, 796-799. [CrossRef] [PubMed]

29. Meng, G.; Szostak, M. Palladium-catalyzed Suzuki-Miyaura coupling of amides by carbon-nitrogen cleavage: General strategy for amide N-C bond activation. Org. Biomol. Chem. 2016, 14, 5690-5707. [CrossRef] [PubMed]

30. Hie, L.; Fine Nathel, N.F.; Shah, T.K.; Baker, E.L.; Hong, X.; Yang, Y.F.; Liu, P.; Houk, K.N.; Garg, N.K. Conversion of amides to esters by the nickel-catalysed activation of amide C-N bonds. Nature 2015, 524, 79-83. [CrossRef] [PubMed]

31. Li, X.; Zou, G. Acylative Suzuki coupling of amides: Acyl nitrogen activation via synergy of independently modifiable activating groups. Chem. Commun. 2015, 51, 5089-5092. [CrossRef] [PubMed]

32. Kraut, J. Serine proteases: Structure and mechanism of catalysis. Annu. Rev. Biochem. 1977, 46, 331-358. [CrossRef] [PubMed]

33. Carter, P.; Wells, J.A. Dissecting the catalytic triad of a serine protease. Nature 1988, 332, 564-568. [CrossRef] [PubMed] 
34. Verma, S.; Dixit, R.; Pandey, K.C. Cysteine proteases: Modes of activation and future prospects as pharmacological targets. Front. Pharmacol. 2016, 7, 107. [CrossRef] [PubMed]

35. Otto, H.H.; Schirmeister, T. Cysteine proteases and their inhibitors. Chem. Rev. 1997, 97, 133-171. [CrossRef] [PubMed]

36. Rawlings, N.D.; Barrett, A.J. MEROPS: The peptidase database. Nucleic Acids Res. 1999, $27,325-331$. [CrossRef] [PubMed]

37. Coulombe, R.; Grochulski, P.; Sivaraman, J.; Menard, R.; Mort, J.S.; Cygler, M. Structure of human procathepsin $\mathrm{L}$ reveals the molecular basis of inhibition by the prosegment. EMBO J. 1996, 15, 5492-5503. [CrossRef] [PubMed]

38. Hooper, N.M. Families of zinc metalloproteases. FEBS Lett. 1994, 354, 1-6. [CrossRef]

39. Hase, C.C.; Finkelstein, R.A. Bacterial extracellular zinc containing metalloproteases. Microbiol. Rev. 1993, 57, 823-837. [PubMed]

40. Barrett, A. J. Proteinases in Mammalian Cells and Tissues; Elsevier/North-Holland Biomedical Press: Amsterdam, The Netherlands, 1977; pp. 181-208.

41. Garrett, R.H.; Grisham, C.M. Biochemistry; University of Virginia: Charlottesville, VA, USA, 2010; p. 103.

42. Hausrath, A.C.; Matthews, B.W. Thermolysin in the absence of substrate has an open conformation. Acta Crystallogr. 2002, 58, 1002-1007. [CrossRef]

43. Endo, S. Studies on protease produced by thermophilic bacteria. J. Ferment. Technol. 1962, 40, 346.

44. Kooi, C.; Sokol, P.A. Differentiation of thermolysins and serralysins by monoclonal antibodies. J. Med. Microbiol. 1996, 45, 219-225. [CrossRef] [PubMed]

45. De Kreij, A.; Venema, G.; van den Burg, B. Substrate specificity in the highly heterogeneous M4 peptidase family is determined by a small subset of amino acids. J. Biol. Chem. 2000, 275, 31115-31120. [CrossRef] [PubMed]

46. Titani, K.; Hermodson, M.A.; Ericsson, L.H.; Walsh, K.A.; Neurath, H. Amino-acid sequence of thermolysin. Nat. New Biol. 1972, 238, 35-37. [CrossRef] [PubMed]

47. Ooshima, H.; Mori, H.; Harano, Y. Synthesis of aspartame precursor by thermolysin solid in organic solvent. Biotechnol. Lett. 1985, 7, 789-792. [CrossRef]

48. Holmquist, B.; Vallee, B.L. Metal substitutions and inhibition of thermolysin: Spectra of the cobalt enzyme. J. Biol. Chem. 1974, 249, 4601-4607. [PubMed]

49. Vallee, B.L.; Auld, D.S. Zinc coordination, function, and structure of zinc enzymes and other proteins. Biochemistry 1990, 29, 5647-5659. [CrossRef] [PubMed]

50. Hangauer, D.G.; Monzingo, A.F.; Matthews, B.W. An interactive computer graphics study of thermolysin-catalyzed peptide cleavage and inhibition by $N$-carboxymethyl peptides. Biochemistry 1984, 23, 5730-5741. [CrossRef] [PubMed]

51. Pelmenschikov, V.; Blomberg, M.R.A.; Siegbahn, P.E.M. A theoretical study of the mechanism of peptide hydrolysis by thermolysine. J. Biol. Inorg. Chem. 2001, 7, 284-298. [CrossRef] [PubMed]

52. Kilshtain, A.V.; Warshel, A. On the origin of the catalytic power of carboxypeptidase A and other metalloenzymes. Proteins 2009, 77, 536-550. [CrossRef] [PubMed]

53. Quicho, F.A.; McMurray, C.H.; Lipscomb, W.N. Similarities between the Conformation of Arsanilazotyrosine 248 of Carboxypeptidase A $a$ in the Crystalline State and in Solution. Proc. Nat. Acad. Sci. USA 1972, 69, 2850-2854. [CrossRef]

54. Wu, S.; Zhang, C.; Xu, D.; Guo, H. Catalysis of Carboxypeptidase A: Promoted-Water versus Nucleophilic Pathways. J. Phys. Chem. B 2010, 114, 9259-9267. [CrossRef] [PubMed]

55. Lazarus, M.B.; Jiang, J.; Kapuria, V.; Bhuiyan, T.; Janetzko, J.; Zandberg, W.F.; Vocadlo, D.J.; Herr, W.; Walker, S. HCF-1 is cleaved in the active site of O-GlcNAc transferase. Science 2013, 342, 1235-1239. [CrossRef] [PubMed]

56. Janetzko, J.; Trauger, S.A.; Lazarus, M.B.; Walker, S. How the glycosyltransferase OGT catalyzes amide bond cleavage. Nat. Chem Biol. 2016, 12, 899-901. [CrossRef] [PubMed]

57. Smith, C.S.; Anderson, M.A.; Hoadley, K.A.; Keck, J.L.; Cleland, W.W.; Denu, J. M. Structural and kinetic isotope effect studies of nicotinamidase (Pnc1) from saccharomyces cerevisiae. Biochemistry 2012, 51, $243-256$. [CrossRef] [PubMed] 
58. Fyfe, P.K.; Rao, V.A.; Zemla, A.; Cameron, S.; Hunter, W.N. Specificity and mechanism of acinetobacter baumanii nicotinamidase: Implications for activation of the front-line tuberculosis drug pyrazinamide. Angew. Chem. Int. Ed. 2009, 48, 9176-9179. [CrossRef] [PubMed]

59. Hu, G.; Taylor, A.B.; McAlister-Henn, L.; Hart, P.J. Crystal structure of the yeast nicotinamidase Pnc1p. Arch. Biochem. Biophys. 2007, 461, 66-75. [CrossRef] [PubMed]

60. Du, X.; Wang, W.; Kim, R.; Yakota, H.; Nguyen, H.; Kim, S.H. Crystal structure and mechanism of catalysis of a pyrazinamidase from Pyrococcus horikoshii. Biochemistry 2001, 40, 14166-14172. [CrossRef] [PubMed]

61. Mukherjee, T.; Zhang, Y.; Abdelwahed, S.; Ealick, S.E.; Begley, T.P. Catalysis of a flavoenzyme-mediated amide hydrolysis. J. Am. Chem. Soc. 2010, 132, 5550-5551. [CrossRef] [PubMed]

62. Massey, V. Activation of molecular oxygen by flavins and flavoproteins. J. Biol. Chem. 1994, 269, 22459. [PubMed]

63. Vaughn, H.L.; Robbins, M.D. Rapid procedure for the hydrolysis of amides to acids. J. Org. Chem. 1975, 40, 1187. [CrossRef]

64. Gao, C.; Lavey, B.J.; Lo, C.L.; Datta, A.; Wentworth, P., Jr.; Janda, K.D. Direct selection for catalysis from combinatorial antibody libraries using a boronic acid probe: Primary amide bond hydrolysis. J. Am. Chem. Soc. 1998, 120, 2211-2217. [CrossRef]

65. Martin, M.T.; Angeles, T.S.; Sugasawara, R.; Aman, N.I.; Napper, A.D.; Darsley, M.J.; Sanchez, R.I.; Booth, P.; Titmas, R.C. Antibody-catalyzed hydrolysis of an unsubstituted amide. J. Am. Chem. Soc. 1994, 116, 6508-6512. [CrossRef]

66. Dai, X.; de Mesmaeker, A.; Joyce, G.F. Cleavage of an amide bond by a ribozyme. Science 1995, 267, $237-241$. [CrossRef] [PubMed]

67. Wezynfeld, N.E.; Fraczyk, T.; Bal, W. Metal assisted peptide bond hydrolysis: Chemistry, biotechnology and toxicological implications. Coord. Chem. Rev. 2016, 327-328, 166-187. [CrossRef]

68. Yashiro, M.; Sonobe, Y.; Yamamura, A.; Takarada, T.; Komiyama, M.; Fujii, Y. Metal-ion-assisted hydrolysis of dipeptides involving a serine residue in a neutral aqueous solution. Org. Biomol. Chem. 2003, 1, 629-632. [CrossRef] [PubMed]

69. Suh, J.H. Model studies of metalloenzymes involving metal-ions as Lewis acid catalysts. Acc. Chem. Res. 1992, 25, 273-279. [CrossRef]

70. Wybon, C.C.D.; Mensch, C.; Hollanders, K.; Gadais, C.; Herrebout, W.A.; Ballet, S.; Maes, B.U.W. Zn-catalyzed tert-Butyl nicotinate-directed amide cleavage as a biomimic of metallo-exopeptidase activity. ACS Catal. 2018, 8, 203-218. [CrossRef]

71. Yashiro, M.; Takarada, T.; Miyama, S.; Komiyama, M. Cerium(IV)-cyclodextrin complex for peptide hydrolysis in neutral homogeneous solutions. J. Chem. Soc. Chem. Commun. 1994, 15, 1757-1758. [CrossRef]

72. Kita, Y.; Nishii, Y.; Higuchi, T.; Mashima, K. Zinc-catalyzed amide cleavage and esterification of beta-hydroxyethylamides. Angew. Chem. Int. Ed. 2012, 51, 5723-5726. [CrossRef] [PubMed]

73. Ho, P.H.; Stroobants, K.; Parac-Vogt, T.N. Hydrolysis of serine-containing peptides at neutral pH promoted by [MoO4]2-oxyanion. Inorg. Chem. 2011, 50, 12025-12033. [CrossRef] [PubMed]

74. Absillis, G.; Parac-Vogt, T.N. hydrolytic activity of vanadate toward serine-containing peptides studied by kinetic experiments and DFT theory. Inorg. Chem. 2012, 51, 9902-9910. [CrossRef] [PubMed]

75. Cartuyvels, E.; Absillis, G.; Parac-Vogt, T.N. Questioning the paradigm of metal complex promoted phosphodiester hydrolysis: [Mo7O24]6-polyoxometalate cluster as an unlikely catalyst for the hydrolysis of a DNA model substrate. Chem. Commun. 2008, 85-87. [CrossRef]

76. Absillis, G.; Cartuyvels, E.; Van Deun, R.; Parac-Vogt, T.N. Hydrolytic cleavage of an RNA-Model phosphodiester catalyzed by a highly negatively charged polyoxomolybdate [Mo7O24]6-Cluster. J. Am. Chem. Soc. 2008, 130, 17400-17408. [CrossRef] [PubMed]

77. Absillis, G.; Van Deun, R.; Parac-Vogt, T.N. Polyoxomolybdate promoted hydrolysis of a DNA-model phosphoester studied by NMR and EXAFS spectroscopy. Inorg. Chem. 2011, 50, 11552-115560. [CrossRef] [PubMed]

78. Takarada, T.; Yashiro, M.; Komiyama, M. Catalytic hydrolysis of peptides by cerium(IV). Chem. Eur. J. 2000, 6, 3906-3913. [CrossRef]

79. Kassai, M.; Ravi, R.G.; Shealy, S.J.; Grant, K.B. Unprecedented acceleration of zirconium(IV)-assisted peptide hydrolysis at neutral pH. Inorg. Chem. 2004, 43, 6130-6132. [CrossRef] [PubMed] 
80. Absillis, G.; Parac-Vogt, T.N. Peptide bond hydrolysis catalyzed by the Wells-Dawson $\operatorname{Zr}(\alpha 2-\mathrm{P} 2 \mathrm{~W} 17 \mathrm{O} 61) 2$ polyoxometalate. Inorg. Chem. 2012, 51, 9902-9910. [CrossRef] [PubMed]

81. Ho, P.H.; Stroobants, K.; Moelants, E.; Proost, P.; Parac-Vogt, T.N. Selective hydrolysis of hen egg white lysozyme at Asp-X peptide bonds promoted by oxomolybdate. J. Inorg. Biochem. 2014, 136, 73-80.

82. Ly, H.G.T.; Fu, G.; Kondinski, A.; Bueken, B.; De Vos, D.; Parac-Vogt, T.N. Superactivity of MOF-808 toward peptide bond hydrolysis. J. Am. Chem. Soc. 2018, 140, 6325-6335. [CrossRef] [PubMed]

83. Meriwether, L.; Westheimer, F.H. Metal ion promoted hydrolysis of glycine amide and of phenylalanylglycine amide. J. Am. Chem. Soc. 1956, 78, 5119. [CrossRef]

84. Bamann, E.; Hass, J.G.; Trapmann, H. Metallionenkatalytische zerlegung der (-CO-NH-)-bindung in peptiden und N-Acetyl-aminosäuren. Arch. Pharm. 1961, 294, 569-580. [CrossRef]

85. Collman, J.P.; Buckingham, D.A. Hydrolytic cleavage of N-terminal peptide bonds by a cobalt chelate. J. Am. Chem. Soc. 1963, 85, 3039-3040. [CrossRef]

86. Buckingham, D.A.; Coliman, J.P.; Happer, D.A.R.; Marzilli, L.G. Hydrolysis of N-terminal peptide bonds and amino acid derivatives by the $\beta$-hydroxoaquotriethylenetetraminecobalt(III) ion. J. Am. Chem. Soc. 1967, 89, 1082-1087. [CrossRef] [PubMed]

87. Bentley, K.W.; Creaser, E.H. Qualitative determination of N-terminal amino acids of peptides and proteins with cobalt (3) chelates. Bfochem. J. 1973, 135, 507-511. [CrossRef]

88. Kimura, E. Sequential hydrolysis of peptides with $\beta$-hydroxoaquo triethylenetetraminecobalt(III) ion. Inorg. Chem. 1974, 13, 951-954. [CrossRef]

89. Erxleben, A. Interaction of molybdocene dichloride with cysteine-containing peptides: Coordination, regioselective hydrolysis, and intramolecular aminolysis. Inorg. Chem. 2005, 44, 1082-1094. [CrossRef] [PubMed]

90. Burgeson, I.E.; Kostic', N.M. Selective hydrolysis of unactivated peptide bonds, promoted by platinum(II) complexes anchored to amino acid side chains. Inorg. Chem. 1991, 30, 4299-4305. [CrossRef]

91. Rajkovic, S.; Zivkovic, M.D.; Djuran, M.I. Reactions of dinuclear platinum(II) complexes with peptides. Curr. Protein Pept. Sci. 2016, 17, 95-105. [CrossRef] [PubMed]

92. Parac, T.N.; Kostic, N.M. New selectivity and turnover in peptide hydrolysis by metal complexes. A palladium(II) aqua complex catalyzes cleavage of peptides next to the histidine residue. J. Am. Chem. Soc. 1996, 118, 51-58. [CrossRef]

93. Živković, M.D.; Rajković, S.; Glišić, B.D.; Drašković, N.S.; Djuran, M.I. Hydrolysis of the amide bond in histidine- and methionine-containing dipeptides promoted by pyrazine and pyridazine palladium(II)-aqua dimers: Comparative study with platinum(II) analogues. Bioorg. Chem. 2017, 72, 190-198. [CrossRef] [PubMed]

94. Rajkovic, S.; Asanin, D.P.; Zivkovic, M.D.; Djuran, M.I. Synthesis of different pyrazine-bridged platinum(II) complexes and ${ }^{1} \mathrm{H}$ NMR study of their catalytic abilities in the hydrolysis of the Nacetylated L-methionylglycine. Polyhedron 2013, 65, 42-47. [CrossRef]

95. Asanin, D.P.; Zivkovic, M.D.; Rajkovic, S.; Warzajtis, B.; Rychlewska, U.; Djuran, M.I. Crystallographic evidence of anion $\cdots \pi$ interactions in the pyrazine bridged $\left\{[\mathrm{Pt}(\mathrm{en}) \mathrm{Cl}]_{2}(\mu-\mathrm{pz})\right\} \mathrm{Cl}_{2}$ complex and a comparative study of the catalytic ability of mononuclear and binuclear platinum(II) complexes in the hydrolysis of N-acetylated L-methionylglycine. Polyhedron 2013, 51, 255-262.

96. Živković, M.D.; Asanin, D.P.; Rajkovic, S.; Djuran, M.I. Hydrolysis of the amide bond in N-acetylated L-methionylglycine catalyzed by various platinum(II) complexes under physiologically relevant conditions. Polyhedron 2011, 30, 947-952. [CrossRef]

97. Rajkovic, S.; Zivkovic, M.D.; Kallay, C.; Sóvágó, I.; Djuran, M.I. A study of the reactions of a methionine- and histidine-containing tetrapeptide with different $\mathrm{Pd}(\mathrm{II})$ and $\mathrm{Pt}(\mathrm{II})$ complexes: Selective cleavage of the amide bond by platination of the peptide and steric modification of the catalyst. Dalton Trans. 2009, 39, 8370-8377. [CrossRef] [PubMed]

98. Zhu, L.; Kostie, N.M. Toward artificial metalloproteases: Mechanisms by which platinum(II) and palladium(II) complexes promote selective, fast hydrolysis of unactivated amide bonds in peptides. Inorg. Chem. 1992, 31, 3994-4001. [CrossRef]

99. Milovic, N.M.; Kostic, N.M. Palladium(II) complexes, as synthetic peptidases, regioselectively cleave the second peptide bond "upstream" from methionine and histidine side chains. J. Am. Chem. Soc. 2002, 124, 4759-4769. [CrossRef] [PubMed] 
100. Milovic, N.; Kostic, N. Palladium(II) complex as a sequence-specific peptidase: Hydrolytic cleavage under mild conditions of X-Pro peptide bonds in X-Pro-Met and X-Pro-His segments. J. Am. Chem. Soc. 2003, 125, 781-789. [CrossRef] [PubMed]

101. Milovic, N.M.; Kostic, N.M. Interplay of terminal amino group and coordinating side chains in directing regioselective cleavage of natural peptides and proteins with palladium(II) complexes. Inorg. Chem. 2002, 41, 7053-7063. [CrossRef] [PubMed]

102. Milovic, N.M.; Badjic, J.D.; Kostic, N.M. Conjugate of palladium(II) complex and $\beta$-cyclodextrin acts as a biomimetic peptidase. J. Am. Chem. Soc. 2004, 126, 696-697. [CrossRef] [PubMed]

103. Yoo, C.E.; Chae, P.S.; Kim, J.E.; Jeong, E.J.; Suh, J. Degradation of myoglobin by polymeric artificial metalloproteases containing catalytic modules with various catalytic group densities: Site selectivity in peptide bond cleavage. J. Am. Chem. Soc. 2003, 125, 14580-14589. [CrossRef] [PubMed]

104. Yoo, S.H.; Lee, B.J.; Kim, H.; Suh, J. Artificial metalloprotease with active site comprising aldehyde group and $\mathrm{Cu}(\mathrm{II})$ Cyclen complex. J. Am. Chem. Soc. 2005, 127, 9593-9602. [CrossRef] [PubMed]

105. Jeon, J.W.; Son, S.J.; Yoo, C.E.; Hong, I.S.; Suh, J. Toward protein-cleaving catalytic drugs: Artificial protease selective for myoglobin. Bioorg. Med. Chem. 2003, 11, 2901-2910. [CrossRef]

106. Kim, H.; Jang, B.; Cheon, Y.; Suh, M.; Suh, J. Proteolytic activity of Co(III) complex of 1-oxa-4,7,10triazacyclododecane: A new catalytic center for peptide-cleavage agents. J. Biol. Inorg. Chem. 2009, 14, 151-157. [CrossRef] [PubMed]

107. Chae, P.S.; Kim, M.-S.; Jeung, C.-S.; Lee, S.D.; Park, H.; Lee, S.; Suh, J. Peptide-cleaving catalyst selective for peptide deformylase. J. Am. Chem. Soc. 2005, 127, 2396-2397. [CrossRef] [PubMed]

108. Suh, J.; Chei, W.S.; Lee, T.Y.; Kim, M.G.; Yoo, S.H.; Jeong, K.; Ahn, J.Y. Cleavage agents for soluble oligomers of human islet amyloid polypeptide. J. Biol. Inorg. Chem. 2008, 13, 693-701. [CrossRef] [PubMed]

109. Lee, T.Y.; Suh, J. Target-selective peptide-cleaving catalysts as a new paradigm in drug design. Chem. Soc. Rev. 2008, 38, 1949-1957. [CrossRef] [PubMed]

110. Suh, J. Progress in designing artificial proteases: A new therapeutic option for amyloid diseases. Asian J. Org. Chem. 2014, 3, 18-32. [CrossRef]

111. De Oliveira, M.C.B.; Scarpellini, M.; Neves, A.; Terenzi, H.; Bortoluzzi, A.J.; Szpoganics, B.; Greatti, A.; Mangrich, A.S.; de Souza, E.M.; Fernandez, P.M.; et al. Hydrolytic protein cleavage mediated by unusual mononuclear copper(II) complexes: X-ray structures and solution studies. Inorg. Chem. 2005, 44, 921-929. [CrossRef] [PubMed]

112. Kopera, E.; Krężel, A., A.; Protas, A.M.; Belczyk, A.; Bonna, A.; Wysłouch-Cieszynska, A.; Poznanski, J.; Bal, W. Sequence-specific Ni(II)-dependent peptide bond hydrolysis for protein engineering: Reaction conditions and molecular mechanism. Inorg. Chem. 2010, 49, 6636-6645. [CrossRef] [PubMed]

113. Ariani, H.H.; Polkowska-Nowakowska, A.; Bal, W. Effect of D-amino acid substitutions on Ni(II)-assisted peptide bond hydrolysis. Inorg. Chem. 2013, 52, 2422-2431. [CrossRef] [PubMed]

114. Ni, J.; Sohma, Y.; Kanai, M. Scandium(III) triflate-promoted serine/threonine-selective peptide bond cleavage. Chem. Commun. 2017, 53, 3311-3314. [CrossRef] [PubMed]

115. Edman, P.; Begg, G.A. Protein sequenator. Eur. J. Biochem. 1967, 1, 80-91. [CrossRef] [PubMed]

116. Gross, E. The cyanogen bromide reaction. Methods Enzymol. 1967, 11, 238.

117. Degani, Y.; Patchornik, A. Cyanylation of sulfhydryl groups by 2-nitro-5-thiocyanobenzoic acid. High-yield modification and cleavage of peptides at cysteine residues. Biochemistry 1974, 13, 1. [CrossRef] [PubMed]

118. Mahoney, W.C.; Smith, P.K.; Hermodson, M.A. Fragmentation of proteins with $o$-iodosobenzoic acid: Chemical mechanism and identification of $o$-iodoxybenzoic acid as a reactive contaminant that modifies tyrosyl residues. Biochemistry 1981, 20, 443-448. [CrossRef] [PubMed]

119. Burstein, Y.; Patchornik, A. Selective chemical cleavage of tryptophanyl peptide bonds in peptides and proteins. Biochemistry 1972, 11, 4641-4650. [CrossRef] [PubMed]

120. Hamada, Y.A. Novel N-terminal degradation reaction of peptides via N-amidination. Bioorg. Med. Chem. Lett. 2016, 26, 1690. [CrossRef] [PubMed]

121. Yamamoto, J.; Denda, M.; Maeda, N.; Kita, M.; Komiya, C.; Tanaka, T.; Nomura, W.; Tamamura, H.; Sato, Y.; Yamauchi, A.; et al. Development of a traceable linker containing a thiol-responsive amino acid for the enrichment and selective labelling of target proteins. Org. Biomol. Chem. 2014, 12, 3821-3826. [CrossRef] [PubMed] 
122. Yamamoto, J.; Maeda, N.; Komiya, C.; Tanaka, T.; Denda, M.; Ebisuno, K.; Nomura, W.; Tamamura, H.; Sato, Y.; Yamauchi, A.; et al. Development of a fluoride-responsive amide bond cleavage device that is potentially applicable to a traceable linker. Tetrahedron 2014, 70, 5122-5127. [CrossRef]

123. Shigenaga, A.; Ogura, K.; Hirakawa, H.; Yamamoto, J.; Ebisuno, K.; Miyamoto, L.; Ishizawa, K.; Tsuchiya, K.; Otaka, A. Development of a reduction-responsive amino acid that induces peptide bond cleavage in hypoxic cells. ChemBioChem 2012, 13, 968-971. [CrossRef] [PubMed]

124. Shigenaga, A.; Hirakawa, H.; Yamamoto, J.; Ogura, K.; Denda, M.; Yamaguchi, K.; Tsuji, D.; Itoh, K.; Otaka, A. Design and synthesis of caged ceramide: UV-responsive ceramide releasing system based on UV-induced amide bond cleavage followed by O-N acyl transfer. Tetrahedron 2011, 67, 3984-3990. [CrossRef]

125. Shigenaga, A.; Yamamoto, J.; Sumikawa, Y.; Furuta, T.; Otaka, A. Development and photo-responsive peptide bond cleavage reaction of two-photon near-infrared excitation-responsive peptide. Tetrahedron Lett. 2010, 51, 2868-2871. [CrossRef]

126. Shigenaga, A.; Yamamoto, J.; Hirakawa, H.; Ogura, K.; Maeda, N.; Morishita, K.; Otaka, A. Development of thiol-responsive amide bond cleavage device and its application for peptide nucleic acid-based DNA releasing system. Tetrahedron Lett. 2010, 51, 2525. [CrossRef]

127. Shigenaga, A.; Tsuji, D.; Nishioka, N.; Tsuda, S.; Itoh, K.; Otaka, A. Synthesis of a stimulus-responsive processing device and its application to a nucleocytoplasmic shuttle peptide. ChemBioChem 2007, 8, 1929-1931. [CrossRef] [PubMed]

128. Kita, M.; Yamamoto, J.; Morisaki, T.; Komiya, C.; Inokuma, T.; Miyamoto, L.; Tsuchiya, K.; Shigenaga, A.; Otaka, A. Design and synthesis of a hydrogenperoxide-responsive amino acid that induces peptide bond cleavage after exposure to hydrogen peroxide. Tetrahedron Lett. 2015, 56, 4228-4231. [CrossRef]

129. Nalbone, J.M.; Lahankar, N.; Buissereth, L.; Raj, M. Glutamic acid selective chemical cleavage of peptide bonds. Org. Lett. 2016, 18, 1186-1189. [CrossRef] [PubMed]

130. Tofteng, A.P.; Sørensen, K.K.; Conde-Frieboes, K.W.; HoegJensen, T.; Jensen, K.J. Fmoc solid-phase synthesis of C-terminal peptide thioesters by formation of a backbone pyroglutamyl imide moiety. Angew. Chem. Int. Ed. 2009, 48, 7411-7414. [CrossRef] [PubMed]

131. Tanabe, K.; Taniguchi, A.; Matsumoto, T.; Oisaki, K.; Sohma, Y.; Kanai, M. Asparagine-selective cleavage of peptide bonds through hypervalent iodine-mediated Hofmann rearrangement in neutral aqueous solution. Chem. Sci. 2014, 5, 2747-2753. [CrossRef]

132. Elashal, H.E.; Raj, M. Site-selective chemical cleavage of peptide bonds. Chem. Commun. 2016, 52, 6304-6307. [CrossRef] [PubMed]

133. Elashal, H.E.; Cohen, R.D.; Raj, M. Fmoc solid-phase synthesis of C-terminal modified peptides by formation of a backbone cyclic urethane moiety. Chem. Commun. 2016, 52, 9699-9702. [CrossRef] [PubMed]

134. Elashal, H.E.; Sim, Y.E.; Raj, M. Serine promoted synthesis of peptide thioester precursor on solid support for native chemical ligation. Chem. Sci. 2017, 8, 117-123. [CrossRef] [PubMed]

135. Elashal, H.E.; Cohen, R.D.; Elashal, H.E.; Raj, M. Oxazolidinone-mediated sequence determination of one-bead one-compound cyclic peptide libraries. Org. Lett. 2018, 20, 2374-2377. [CrossRef] [PubMed]

136. Elashal, H.E.; Cohen, R. D.; Elashal, H.E.; Zong, C.H.; Link, A.J.; Raj, M. Cyclic and lasso peptides: Sequence determination, topology analysis, and rotaxane formation. Angew. Chem. Int. Ed. 2018, 57, 6150-6154. [CrossRef] [PubMed]

137. Komiya, C.; Aihara, K.; Morishita, K.; Ding, H.; Inokuma, T.; Shigenaga, A.; Otaka, A. Development of an intein-inspired amide cleavage chemical device. J. Org. Chem. 2016, 81, 699-707. [CrossRef] [PubMed]

138. Jung, M.E.; Piizzi, G. Gem-Disubstituent effect: Theoretical basis and synthetic applications. Chem. Rev. 2005, 105, 1735-1766. [CrossRef] [PubMed]

139. Bachrach, S.M. The gem-dimethyl effect revisited. J. Org. Chem. 2008, 73, 2466-2468. [CrossRef] [PubMed]

140. Beesley, R.M.; Ingold, C.K.; Thorpe, J.F. CXIX-The formation and stability of spiro-compounds. Part I. spiro-compounds from cyclohexane. J. Chem. Soc. Trans. 1915, 107, 1080-1106. [CrossRef]

141. Bochet, C.G. Photolabile protecting groups and linkers. J. Chem. Soc. Perkin Trans. 2001, 2, 125-142.

142. Brieke, C.; Rohrbach, F.; Gottschalk, A.; Mayer, G.; Heckel, A. Light-controlled tools. Angew. Chem. Int. Ed. 2012, 51, 8446-8476. [CrossRef] [PubMed]

143. Seki, Y.; Tanabe, K.; Sasaki, D.; Sohma, Y.; Oisaki, K.; Kanai, M. Serine-selective aerobic cleavage of peptides and a protein using a water-soluble copper-organoradical conjugate. Angew. Chem. Int. Ed. 2014, 53, 6501-6505. [CrossRef] [PubMed] 
144. Samaritoni, J.G.; Copes, A.T.; Crews, D.K.; Glos, C.; Thompson, A.L.; Wilson, C.; O’Donnell, M.J.; Scott, W.L. Unexpected hydrolytic instability of $\mathrm{N}$-acylated amino acid amides and peptides. J. Org. Chem. 2014, 79, 3140-3151. [CrossRef] [PubMed]

145. Shimizu, Y.; Noshita, M.; Mukai, Y.; Morimoto, H.; Ohshima, T. Cleavage of unactivated amide bonds by ammonium salt-accelerated hydrazinolysis. Chem. Commun. 2014, 50, 12623-12625. [CrossRef] [PubMed]

146. Qiu, Y.; Hemu, X.; Liu, D.X.; Tam, J.P. Selective bi-directional amide bond cleavage of N-methylcysteinyl peptide. Eur. J. Org. Chem. 2014, 20, 4370-4380. [CrossRef]

147. Creighton, C.J.; Romoff, T.T.; Bu, J.H.; Goodman, M. Mechanistic studies of an unusual amide bond scission. J. Am. Chem. Soc. 1999, 121, 6786-6791. [CrossRef]

(C) 2018 by the authors. Licensee MDPI, Basel, Switzerland. This article is an open access article distributed under the terms and conditions of the Creative Commons Attribution (CC BY) license (http://creativecommons.org/licenses/by/4.0/). 